\title{
Stigma's Opening: Grutter's Diversity Interest(s) and the New Calculus for Affirmative Action in Higher Education
}

\author{
Joshua M. Levine $\dagger$
}

\section{INTRODUCT1ON}

"In summary, the Equal Protection Clause does not prohibit the Law School's narrowly tailored use of race in admissions decisions to further a compelling interest in obtaining the educational benefits that flow from a diverse student body." So concluded Justice Sandra Day O'Connor's majority opinion in Grutter v. Bollinger upholding the University of Michigan Law School's affirmative action policy. Affirmative action in higher education, it seems, is now on more solid ground because a majority of the Court for the first time has endorsed Justice Lewis Powell's lone opinion in Regents of the University of California v. Bakke ${ }^{2}$ affirming the value of diversity in such a setting. ${ }^{3}$ Bakke was the first-and before Grutter, the only-case in which the Supreme Court examined the constitutionality of affirmative action in the context of university admissions. Since O'Connor herself referred to the Bakke decision and wrote that "today we endorse

Copyright $\odot 2006$ Califomia Law Review, Inc. Califomia Law Review, Inc. (CLR) is a Califomia nonprofit corporation. CLR and the authors are solely responsible for the content of their publications.

$\dagger$ J.D., School of Law, University of Califomia, Berkeley (Boalt Hall), 2005. Email: levinejm@gmail.com. I am deeply grateful to Professor Goodwin Liu for being so generous with his time, feedback, and kindness during the development of this project. 1 am indebted to David Alban, Shawn Bayem, Michael Gilbert, Pop Kessler, Emily Pan, and Emily Zarins for their help at various stages. I have also benefited from my conversations with countless others about the Michigan cases and the overall topic of affirmative action. The people I just thanked do not necessarily agree with everything contained in this Comment and should not share the blame for any of its shortcomings.

1. Grutter v. Bollinger, 539 U.S. 306, 343 (2003).

2. 438 U.S. 265 (1978).

3. Four other Justices signed on to O'Connor's opinion, but six Justices in total seem to have accepted the diversity rationale. Justice Kennedy wrote separately in Grutter to state that he agreed with Chief Justice Rehnquist's dissent that the Court's opinion did not really apply strict scrutiny because it accorded too much deference to the University of Michigan. Yet he also agreed with the majority that diversity is a compelling state interest. See Grutter, 539 U.S. at 387-88 (Kcnnedy, J., dissenting). 
Justice Powell's view that student body diversity is a compelling state interest that can justify the use of race in university admissions," 4 it would be only natural to think of her decision for the Court as an emphatic endorsement of Powell's opinion twenty-five years earlier. Could Justice O'Connor have been any clearer about what Grutter stands for? How can we not take her at her word?

Most of the mainstream press and legal commentary surrounding the Court's decisions in Grutter and its companion case, Gratz v. Bollinger, ${ }^{5}$ agreed that the Court, through O'Connor's majority opinion in Grutter, firmly endorsed Powell's Bakke opinion for the first time-and that this was Grutter's significance. ${ }^{6}$ I concur in part and dissent in part. Although Bakke's diversity interest survived and gained the support of a majority of Justices in the Michigan cases, this common account of these cases fails to capture the full significance of what O'Connor's Grutter opinion really did. Contrary to O'Connor's seemingly conclusive statements, Grutter's reasoning relied on much more than the educational benefits of diversity,

4. Id. at 325 (majority opinion).

5. 539 U.S. 244 (2003).

6. See, e.g., Susan Low Bloch, Essay, Looking Ahead: The Future of Affirmative Action, 52 Am. U. L. Rev. 1507, 1513 (2003) (stating that the Court in Grutter "made the very significant decision that the University's desire to achieve diversity in its student body was in fact a compelling governmental interest, relying heavily on the reasoning of Justice Powell's lone opinion in Bakke"); Erwin Chemerinsky, October Term 2002: Value Choices by the Justices, Not Theory, Determine Constitutional Law, 6 GreEn BAG 2D 367, 369 (2003) ("The bottom line is that the Court adhered to the position articulated by Justice Lewis Powell in Bakke a quarter century ago: Diversity is a compelling intercst in education and universities may use race as a factor to ensure diversity, but quotas or numerical quantification of benefits is impermissible."); Linda Greenhouse, In a Momentous Term, Justices Remake the Law, and the Court, N.Y. TImEs, July 1, 2003, at Al ("Justice O'Connor's majority opinion in Grutter v. Bollinger ... found that the program, both in its operation and in its diversity rationale, comported with the controlling opinion by Justice Lewis F. Powell Jr. in the Bakke case 25 years ago."); Editorial, Supreme Court Quotas, WALL ST. J., June 24, 2003, at A16 ("In a part of his [Bakke] opinion that was joined by no other Justice, Powell argued that 'diversity' is a compelling state interest. ... Now Justice O'Connor, writing for the majority on the law-school case, has given that view the fifth vote it needed to become the law of the land."); Peter Schuck, Reflections on Grutter, JuRIST, Sept. 5, 2003, http://jurist.law.pitt.edu/forum/symposium-aa/schuck.php ("The Grutter majority famously ratifies Justice Powell's embrace in Bakke of student diversity as a compelling state interest sufficient to justify university admissions preferences...."); cf. Vikram David Amar \& Evan Caminker, Constitutional Sunsetting?: Justice O'Connor's Closing Comments in Grutter, 30 Hastings Const. L.Q. 541, 548 (2003) ("The centrality of Justice Powell's Bakke opinion is further illustrated by how tightly Justice O'Connor's writing in Grutter tracks not only Powell's reasoning, but also his exact language. Even putting aside the part of the Grutter opinion before the Court said it was endorsing Powell's approach, Justice O'Connor quoted extensively from Justice Powell a whopping sixteen times. To endorse and cite a case and suggest independent agreement with it is one thing; to cannibalize all its key formulations suggests that the case is doing a great deal of the work."). But see, e.g., Kenneth L. Karst, The Revival of Forward-Looking Affirmative Action, 104 Colum. L. Rev. 60, 60 (2004) ("The Grutter opinion also takes the Court a step further, justifying affirmative action for a purpose Justice Powell had not mentioned."); Robert C. Post, The Supreme Court, 2002 Term-Foreword: Fashioning the Legal Constitution: Culture, Courts, and Law, 117 Harv. L. Rev. 4, 59 (2003) ("Although Grutter casts itself as merely endorsing Justice Powell's opinion in Bakke, Grutter's analysis of diversity actually differs quite dramatically from Powell's."). 
and in doing so went far beyond the bounds of the diversity rationale in Powell's Bakke opinion. While some say the most significant change the Michigan cases brought to bear on affirmative action law and policy was their emphasis on the need for "individualized" admissions procedures, this Comment argues that the real legal significance of Grutter is that it not only reaffirmed the diversity rationale in Bakke but also gave two additional rationales for affirmative action - not only the benefits for white people and universities, but also the benefits both for society at large and for racial minorities.

Another common view of Grutter, at least among some of the most ardent supporters of affirmative action, was that Justice Clarence Thomas's dissenting opinion was merely the emotional rant of an angry, ungrateful African American who had benefited from affirmative action but now sought to pull up the ladder behind him. ${ }^{8}$ Specifically, these commentators pointed to his arguments regarding affirmative action's stigmatizing effects as being personal and somehow less than legal in character. ${ }^{9}$ This, too, is a

7. On this subject, Professor Goodwin Liu's definitions are useful and apply to my Comment as well:

Although I use the term "minority" to label applicants who benefit from affirmative action and the term "white" to label those who do not, I recognize that some minority applicants do not benefit from affirmative aetion and that some affirmative action programs may benefit disadvantaged whites. Given this reality, it is probably more precise to use the generic terms "preferred" and "nonpreferred" applicants. But I stick to the terms "minority" and "white" in order to track the usage in common discourse on affirmative action.

Goodwin Liu, The Causation Fallacy: Bakke and the Basic Arithmetic of Selective Admissions, 100 MiCH. L. REv. I045, I046 n.7 (2002). Minority applicants who "do not benefit from affirmative action" refers to members of those minority groups not "preferred" by universities-those groups that are not "underrepresented" and, accordingly, for whom no "plus" is given in admissions.

8. See, e.g., Maureen Dowd, Editorial, Could Thomas Be Right?, N.Y. TimEs, June 25, 2003, at A25 ("[Thomas] knew that he could not make a powerful legal argument against racial preferences, given the fact that he got into Yale Law School and got picked for the Supreme Court thanks to his race. So he made a powerful psychological argument ... . The dissent is a clinical study of a man who has been driven barking mad by the beneficial treatment he has received."); $c f$. Mary Kate Kearney, Justice Thomas in Grutter v. Bollinger: Can Passion Play a Role in a Jurist's Reasoning?, 78 ST. JoHN's L. REv. 15, 26 n.67 (2004) (reeounting other opinion articles strongly eriticizing Thomas's dissent).

9. See, e.g., Michael C. Dorf, The Supreme Court's Divided Rulings in the University of Michigan Affirmative Action Cases: What Does it All Mean?, FindLAw's WriT, June 25, 2003, http://writ.news.findlaw.com/dorf/20030625.html ("Is Justice Thomas a Radical Egalitarian? No, He's Just Angry. ... [T] he real heart of Justice Thomas's dissent in Grutter is more personal. He harbors an almost visceral hatred for what he terms 'know-it-all elites.' ... How did this graduate of Yale Law School come to despise the sort of institution that opened so many doors for him? The answer, it seems, is that he believes affirmative aetion stigmatizes not only its beneficiaries, but all people of color ...."). Dorf does, however, acknowledge that Thomas "has a point" in that stigmatization occurs. Id.

For similar arguments, see also Dowd, supra note 8; Kearney, supra note 8, at 24-26, 35 (describing Thomas's stigma argument as part of a "move away from the legal analysis of the earlier sections of his opinion" and characterizing it as a "a more personal critique of the majority's analysis," though finding Thomas's rhetoric appropriate in that its "passion... infused his reasoning with a power that is difficult to ignore"). 
misconception, and it is related to the one above. Part II of this Comment explains how the O'Connor and Thomas opinions in Grutter shed important light on one another and ought to be read together to understand the path the legal and policy debates over affirmative action (at least in the education context) will likely take in the coming years. In doing so, Part II demonstrates that Thomas's dissent was a legal response to O'Connor's rationale that diversity in education benefits racial minorities; among other things, Thomas's opinion asserted that the affirmative action does "positive injury" to those it purportedly aims to help. ${ }^{10}$ Chief among these injuries to minorities is the stigma carried by those whom affirmative action policies supposedly help. ${ }^{11}$ Part II shows how the old Bakke diversity rationale did not leave an opening for this counterargument, but that O'Connor's new diversity rationales allowed Thomas to legitimately advance his argument of racial stigma. If stigmatic harm ends up undermining the diversity rationale for racial minorities, this would raise important questions about the very nature of the Grutter diversity interest(s) that are currently the law of the land. Contrary to the conventional wisdom, Grutter may actually be weaker than Bakke. In short, Part II demonstrates how affirmative action in higher education has a new constitutional calculus after Grutter.

Part III begins to illustrate stigma's opening into this new calculus. Building on the doctrinal analysis of the first two sections, Part III examines the potential for a lawsuit challenging the constitutionality of a university's affirmative action program because of the stigmatic injury it causes racial minorities. ${ }^{12}$ Under the normal affirmative action litigation paradigm, the plaintiffs are white people who were not admitted to a selective university, supposedly as a result of affirmative action. ${ }^{13}$ Part III lays out a new model in which the challengers are racial minorities applying to a selective university with an affirmative action policy who would be admitted to the university during, but not necessarily because of, ${ }^{14}$ the affirmative action

10. Cf. Gruttcr v. Bollinger, 539 U.S. 306, 350 (2003) (Thomas, J., concurring in part and dissenting in part).

11. This argument goes against the assumption widely held by both conservatives and liberals that affirmative action policies benefit racial minorities and harm whitcs. Indeed, the question is often how much whites are harmed and how much racial minorities are helped. For example, in the context of admissions chances, see Liu, supra note 7.

12. Professors Eric Posner and Adrian Vermeule have observed that "there are few, if any, ... examples of challenges to race-based affirmative action programs by beneficiaries claiming that the program is stigmatizing or demeaning. The stigma critique of affirmative action remains mostly a rhetorical trope of its opponents rather than a litigated issue for the courts." Eric A. Posner \& Adrian Vermeule, Essay, Reparations for Slavery and Other Historical Injustices, 103 Colum. L. Rev. 689, 724 (2003). As a result, "the absence of litigated challenges to race-based prefcrence schemes by beneficiaries also means that the relevant legal questions are largely terra incognita." Id. at 724-25. Part III of this Comment aims to begin to map this terrain.

13. See generally Liu, supra notc 7.

14. Cf. infra Parts III.A.l.a (hypothetical plaintiff Adams) and 1II.A.1.b (hypothetical plaintiff Baker). 
policy's existence. Part III opens with an inquiry into the standing of various hypothetical plaintiffs, not only to raise doctrinal challenges and other issues associated with bringing such litigation, but to look more closely at the kinds of stigmatic injury that may be asserted. It then examines the stigmatic challenge under the new, post-Grutter calculus set forth in Parts I and II, raising issues that may arise under both the compelling interest and narrow tailoring prongs of strict scrutiny. ${ }^{15}$ For example, what kinds of information can be used to help determine whether stigmatic harm defeats a compelling interest? Are there ways to acknowledge stigmatization but narrowly tailor affirmative action policies to minimize or eliminate it?

The ambition of this Comment is to present an alternative account of the diversity interest(s) in Grutter, and therefore an account of what the Michigan cases may mean for the future legality of universities' affirmative action programs. As such, it is mainly an analytical examination of what Grutter leaves open. This Comment concludes, however, with a few thoughts on why this opening-stigma's opening, in particular-is a positive development. But regardless of what one thinks of the merits of this opening, Grutter has wrought a significant doctrinal change that future litigants and others would do well to heed. Since future cases will inevitably build on the experience of the most recent ones, this Comment ultimately concludes by setting forth some lessons the Michigan litigation ought to teach both sides of the affirmative action debate, offering some predictions and recommendations to point a way forward for the next twenty-five years of litigation and policymaking under the new calculus.

\section{I \\ Diversity RELOADED: From BAKKE TO GRUTTER}

\section{A. Powell and Bakke: The Educational Benefits of Diversity}

The diversity interest that Powell's Bakke opinion endorsed was a narrow one, based on pedagogical concerns and rooted constitutionally in Justice Felix Frankfurter's "four essential freedoms" for academiaspecifically, a university's freedom "to determine for itself on academic grounds... who may be admitted to study."16 As Powell wrote, "The atmosphere of speculation, experiment and creation-so essential to the quality of higher education-is widely believed to be promoted by a

15. Racial classifications are constitutional "only if they are narrowly tailored to further compelling governmental interests." Grutter, 539 U.S. at 326.

16. Regents of the Univ. of Cal. v. Bakke, 438 U.S. 265, 312 (1978) (opinion of Powell, J.) (quoting Sweezy v. New Hampshire, 354 U.S. 234, 263 (1957) (Frankfurter, J., concurring) ("It is the business of a university to provide that atmosphere which is most conducive to speculation, experiment and creation. It is an atmosphcre in which there prevail 'the four essential freedoms' of a university-to determine for itself on academic grounds who may teach, what may be taught, how it shall be taught, and who may be admitted to study.")). 
diverse student body." ${ }^{17}$ Powell extolled the value of diversity in the classroom-the educational benefits students derive from coming into contact with diverse viewpoints and the resulting "robust exchange of ideas."18 Such interactions, Powell noted, are central to the mission of universities.

Writing one year after the Bakke decision, Vincent Blasi wondered whether Powell's opinion, which bridged two camps of four Justices each, actually rested on any theory. Blasi concluded that "Mr. Justice Powell does have a theory. It is a theory which requires that admissions programs treat minority-race applicants as persons who have something valuable to contribute to the educational environment rather than as persons who need special help." 19 This is a fair characterization, and it is also revealing about the scope of Powell's opinion; such a theory, while not necessarily patronizing to racial minorities or viewing them as inferior, is vulnerable to the charge that it does not seem to really care about benefiting them either. The Bakke diversity rationale, with its emphasis on minorities' "contribut[ion],"20 is about the use of people of color to advance the university's educational goals for its (mostly) white students.

To illustrate this argument, imagine two portraits of a classroom on a selective university's campus. The first portrait-"Before"-is of a classroom without affirmative action, and the second portrait - "After"-is the same classroom with affirmative action. In the "After" portrait, which has far more people of color than "Before,"21 the students who actually encounter this change and now benefit from the more "robust" learning environment (which to Powell was affirmative action's only permissible rationale) are the (mostly) white students who were in the first picture. Powell's diversity rationale is really a description of the benefits of diversity for (mostly) white people; in other words, the benefits from the vibrant "exchange of ideas" 22 described above are for those students already there at the university. To be generous to Powell, it can be argued that the benefits from affirmative action for racial minorities were assumed-after all, they gain admission and access to the institution. But the Bakke decision concerns the educational benefits of diversity as a compelling interestand the educational experience that is supposedly improved in Generic University's classrooms, compared to the earlier educational experience without affirmative action, is that of (mostly) whites. ${ }^{23}$

\footnotetext{
17. Id.

18. Id.

19. Vincent Blasi, Bakke as Precedent: Does Mr. Justice Powell Have a Theory?, 67 CALIF. L. REV. 21, 67 (1979).

20. See id.; Bakke, 438 U.S. at 313 (opinion of Powell, J.).

21. See also infra notes 216-217 and accompanying text.

22. Bakke, 438 U.S. at 312 (opinion of Powell, J.).

23. My use of the portrait imagery should not be construed as an argument that diversity is solely an aesthetic interest. $C f$. When Logic Fails, SLATE, Email from Walter Dellinger to Dahlia Lithwick, June 25, 2003, http://slate.msn.com/id/2084657/entry/2084857 (anticipating that valuing the "turn to
} 
To justify affirmative action in terms of its benefit to the racial majority seems odd at best and constitutionally questionable at worst. ${ }^{24}$ It is vulnerable to the charge that the "academic freedom" logic underlying it has no logical endpoint: what can the university not do to attain the cducational benefits of diversity? It is also vulnerable to the argument that the rationale itsclf should focus on racial minorities because of past injustices and their ongoing vestiges. ${ }^{25}$ Finally, the rationale is vulnerable to the charge that it uses minorities as props-voices of difference present solely to further the education of whites ${ }^{26}$ The rationale, by not addressing the benefits to racial minorities, seems to allow universities to invite in certain students not (mainly) to study medicine or law but with an ulterior motive: to educate their fellow students. ${ }^{27}$

Tcchnicolor" of the photographs of Duke Law School classes from the 1960s to the 1970s would be criticized by Justice Thomas as evidence of "racial acsthetics," and responding that "the vibrancy of the more recent class pictures is reflected in the classroom"). My point is that the difference that accounts for this change in "vibrancy" is that more racial minorities are in the picture and that the improved classroom experience is only "improved" for the group that would be there before-that is, for (mostly) whites.

24. It would also call into doubt some theoretical justifications for affirmative action. For example, if affirmative action were actually for the racial majority, its more relaxed scrutiny under John Hart Ely's theories would be imperiled. See John Hart Ely, The Constitutionality of Reverse Racial Discrimination, 41 U. CHI. L. REv. 723, 727 (1974).

25. Cf. Derrick Bell, Race, Racism, and American Law $\S 5.12 .1$, at 208 (5th ed. 2004) ("Justice Powell obviated the need for past discrimination by including minority admissions within the broad range of discrction that universities have long exercised in the admissions process to obtain, inter alia, diversity in the admitted student body. Thus, those minorities admitted are not recciving a benefit because of past discrimination, but rather are simply adding to the diversity of their classes."). According to Bell, "[t]he Grutter majority accepted Justice Powell's rationale," id., a characterization 1 contend does not fully capture what the Grutter majority did. See infra Part 1.B.

26. E.g., Charles R. Lawrence III \& Mari J. Matsuda, We Won't Go Back: Making the CASE FOR AffiRmative ACTION 27 (1997). Speaking from white society's point of view, the authors say sarcastically:

We also recognize that it would help the children of the powerful to learn more about the nonwhite world if a few nonwhites were around, but we will decide whom to invite. We will decide who is qualified to serve our purpose of creating an environment where we can learn what we need to know about them.

Id. Responding to the charge "that students in effect serve as their professors' educational 'instruments,' to be used to develop points the professor believes germane to the topic of the course," Professor Sanford Levinson says he

plead[s] guilty . . I l believe that teachers often, and properly, do attempt to draw on the experiences of their students in order to illuminate matters under discussion. . . One need not believe that students should be appointed full professors in order to recognize that even the most untutored first-year student may, because of his or her own life experiences, have something valuable to contribute to a particular classroom discussion.

SANFORd LeVINSON, Wrestling WITH Diversity $41 \mathrm{n} .98$ (2003). Levinson surely is not alone in this belief. However, it is one thing to say that students teaching each other is good pedagogically; it would be quite different to say that this is the reason those student-teachers should be there-that this is a rationale for affirmative action.

27. Universities can be criticized for viewing even this rationale too narrowly-for example, by expecting racial minorities to educate their fellow students in certain subjects in which universities assume they might have special knowledge or expertise. On the television program 60 Minutes, thenMichigan Law School Dean Jeffrey Lehman said: 
Michael Dorf both echoes and softens this last criticism: "Broadly speaking, Powell's Bakke opinion had come to be read for the proposition that a voluntary university affirmative action program cannot be justified by the external impact of the university's graduates. Rather, it must be sustained on the basis of the internal effect of the student body's composition. ${ }^{28}$ One does not have to denounce the educational benefits of diversity as an aesthetic interest to notice the Bakke rationale's focus on internal educational effects. Schools may believe quite altruistically that they want their students not only to see difference but also to learn from those with whom - due to "white flight," self-segregation, or other reasons - they interact less and less in their formative years. Diversity may be more than a rationale for universities to achieve a smiling rainbow on their viewbook covers; it may also be about creating learning opportunities for students to be challenged. But believing in diversity's educational benefits is an internal rationale for the (mostly) whites who were already or about to be there.

As I show in the next Section, however, Justice O'Connor's Grutter opinion shifted the focus of the diversity rationale away from Justice Powell's internal pedagogical effects, giving attention to the affirmative action policy's external impact (and more).

\section{B. O'Connor and Grutter}

For many defenders of affirmative action, the months leading up to the Court's decisions in the Michigan cases were filled with worry that the Court would use these cases to turn its back on Bakke. Consequently, the fact that Justice Powell's rationale was not rejected outright was a great relief to many. That Powell's identification of the diversity rationale for affirmative action in higher education was actually endorsed for the first

When we teach our students about difficult issues such as whether it's appropriate for police to be able to use race profiles when you stop people in traffic stops, when we ask our students whether it's appropriate to decriminalize crack cocaine, the discussion, the analysis, the learning that takes place is better in a racially diverse classroom.

60 Minutes (CBS television broadcast, Oct. 29, 2000), available at http://www.cirusa.org/articles/michigan_60minutes.html. One hopes that this list of issues is neither cxhaustive nor typical. Surely the school does not admit black students only to add their diverse viewpoints to discussions in which the subject of race is a central concern. Otherwise, one may doubt how much racial stereotypes are really being broken down through classroom discussions.

28. Dorf, supra note 9. He goes on:

That may not have been quite what Powell originally meant. In any case, this contention was easily mocked: Was the real reason for affirmative action, critics asked, so that the minority students could enhance the educational experience of the non-minority students? Were minority students merely there to providc a kind of cultural exchange program for the nonminorities? 
time by a majority of the Court was cause for celebration by most affirmative action supporters. ${ }^{29}$

Moreover, Grutter went beyond Bakke in an obvious way: Bakke, despite offering the diversity rationale, had held UC Davis's admissions program unconstitutional. By contrast, Grutter not only affirmed the diversity rationale but also found an admissions program (that of the University of Michigan Law School) to its liking.

The Grutter decision was also significant because it followed Bakke's forward-looking mindset. Professor Kathleen Sullivan, writing in response to three non-education affirmative action cases decided in the $1985 \mathrm{Term}$, lamented that the Court had never "broken out of sin-based rationales to elaborate a paradigm that would look forward rather than back, justifying affirmative action as the architecture of a racially integrated future. Quite the contrary, the Court has avoided such forward-looking justifications...." ${ }^{30}$ Sullivan observed that "such forward-looking visions appeared only fleetingly in the Court's opinions," noting how Powell's vote in Bakke, which "furnished a fifth vote for Bakke's second holding" that allowed race to be explicitly considered in university admissions so long as quotas were not used, was based on the compelling interest of student-body diversity ${ }^{31}$ - a rationale shared by no other Justice, since the four Justices Powell joined to produce a majority for this holding had based their opinion on a remedial, "backward-looking" justification. "The Court never produced a majority for such aspirational justifications, however," 33 such as that found in Powell's Bakke rationale, and this was still the situation when the Michigan affirmative action programs were being litigated. Although it is beyond the scope of this Comment to consider whether a forward-looking rationale is normatively appealing, ${ }^{34}$ or whether it can, should, or will be extended to non-university settings, Sullivan and those of

29. See Charles Lane, Affirmative Action for Diversity Is Upheld, WASH. Post, June 24, 2003, at A01 (describing the reaction of University of Michigan President Mary Sue Coleman, among others).

30. Kathleen M. Sullivan, Supreme Court, 1985 Term-Comment: Sins of Discrimination: Last Term's Affirmative Action Cases, 100 HARV. L. REV: 78, 80 (1986).

31. Id. at 84 .

32. Id. at 82 (citing Regents of the Univ. of Cal. v. Bakke, 438 U.S. 265, 362 (1978) (opinion of Brennan, White, Marshall \& Blackmun, JJ.)). Sullivan also cited the dissent by Justice Stevens in Fullilove v. Klutznick as expressing a forward-looking vision. Id. at 84 ("And Justice Stevens wrote in his Fullilove dissent that he would have viewed Congress's set-aside for minority businesses as justified not only as a remedy, but also as a means of 'facilitating and cncouraging the participation by minority business enterprises in the economy,' if he had found the set-aside actually tailored to either goal.”) (citing Fullilove v. Klutznick, 448 U.S. 448, 542-43, 552 (1980) (Stevens, J., dissenting)).

33. Id.

34. Some critical race scholars criticize affirmative action polieies for being forward-looking and not "rooted in [the] history" of blacks in America. See, e.g., Richard Delgado, Affirmative Action as a Majoritarian Device: Or, Do You Really Want to Be a Role Model?, 89 Mich. L. Rev. 1222, 1223-26 (1991) ("The system thus bases inclusion of people of color on principles of social utility, not reparations or rights. . . The program was designed by others to promote thcir purposes, not ours."). 
similar beliefs should be encouraged by the fact that Powell's aspirational justification is now much less lonely.

Still, O'Connor's opinion cannot be reduced to the shorthand of "Powell's Bakke opinion gets five votes; affirmative action wins," for O'Connor's forward-looking aspirations were aimed much more broadlyand were much more ambitious-than Powell's. Thus, it is inaccurate to say merely that Grutter reaffirmed Bakke. ${ }^{35}$ Rather, Grutter has added to the content of Bakke's diversity rationale. ${ }^{36}$ I view its reconceptualization of diversity as remaining aspirational but extending the sphere of whom diversity exists to benefit.

\section{Diversity's Benefits for White People and the University}

Before detailing the additions, it must be noted that O'Connor did not abandon Powell's rationale but instead solidified it. ${ }^{37}$ As shown at the outset of this Comment, the plain language of O'Connor's conclusions points to a reaffirmation of Bakke's rationale. Indeed, the University of Michigan's policy stated that it aspired to "achieve that diversity which has the potential to enrich everyone's education and thus make a law school class stronger than the sum of its parts." ${ }^{38}$ According to O'Connor, "[t]hese benefits are 'important and laudable,' because 'classroom discussion is livelier, more spirited, and simply more enlightening and interesting' when

35. See supra note 6.

36. In Part II, infra, I raise the issue of whether this expansion of the rationale has made it stronger or weaker.

37. See also supra note 6.

38. Grutter v. Bollinger, 539 U.S. 306, 315 (2003) (quoting Michigan's policy). In faimess, the university crafted its policy-or at Ieast its defense-to comply with Bakke's diversity argument; the policy was not necessarily motivated (primarily, at least) by the educational benefits of diversity. See Lee C. Bollinger, A Comment on Grutter and Gratz v. Bollinger, 103 ColuM. L. Rev. 1589, 1590-9I (2003) ("The only justification Powell allowed was that of achieving diversity for educational purposes, because of an educational judgment that bringing peoplc together from different backgrounds and life experiences would enhance the learning environment for all students. The 'diversity' rationale was thus the critical element in any constitutional defense of affirmative action in higher education, unless one were prepared to abandon Powell's opinion and seek an alternative new basis altogether. The difficulty this posed for higher education was essentially that no one really believed that the past could or should be ignored or that the present society is by any means free of discrimination."); see also Paul Brest, Some Comments on Grutter v. Bollinger, 5I Drake L. Rev. 683, 685-86 (2003) ("Justice Powell did not explicitly address a rationale for affirmative action that many law school deans, myself included, believe is at least as compelling: increasing the minority presence in the legal profession, and especially increasing the presence of African Americans in elite positions in the profession. Perhaps because Justice Powell seemed at best cool to any rationale other than the educational benefits of diversity, most universities subsequently designed and justified race-based admissions programs in these terms."). Note that even though Michigan used the language of "everyone's education" in its policy, since the university is really tracking Powell's rationale one may rightly wonder whose education is "enrich[ed]" if not those who would be at the law school before (and without) such enrichment? In other words, primarily white students would benefit from such "enrich[ment]" because, before the affirmative action admissions policy was put in place (or, without such a policy in place), the university was (or would be) composed primarily of white students. 
the students have 'the greatest possible variety of backgrounds." 39 This is in line with a study by University of Michigan sociologist Patricia Gurin, who provided expert support in the Michigan cases and whose research found that "[s]tudents who experienced the most racial and ethnic diversity in classroom settings and in informal interactions with peers showed the greatest engagement in active thinking processes, growth in intellectual engagement and motivation, and growth in intellectual and acadcmic skills."40

O'Connor's “diversity's benefits for whites" rationale, then, might seem like Bakke redux, augmented by a citation to subsequent social science. But Grutter broadened Bakke with two additional diversity rationales: diversity's benefits for society at large and diversity's benefits for racial minorities. ${ }^{41}$

\section{Diversity's Benefits for Society}

As I have mentioned, the first of Grutter's new diversity rationales focuses on diversity's benefits to society at large. ${ }^{42}$ In adopting this

39. Grutter, 539 U.S. at 330 (quoting district court's ruling); $c f$. Chemerinsky, supra note 6, at 369 (stating that the Michigan decisions "offer guidance in a crucial respect: a majority of the Court has made the value choice that diversity in education is a compelling government interest. I have been a law professor for 23 years, and have taught constitutional law in classrooms that varied from being almost entirely white to having a significant number of minority students. The classroom conversations - and the educational experience for all-is radically different in these contexts. Discussions about racial profiling, affirmative action, jury selection, or countless other topics are changed depending on whether the classroom is diverse or not.").

40. Patricia Gurin, Expert Report of Patricia Gurin, 5 Mich. J. RaCE \& L. 363, 365 (1999). For a catalog of six challenges to the Gurin report and the educational benefits of diversity rationale, see Peter H. Schuck, Diversity in America: Keeping Government at a Safe Distance 167-69 (2003).

41. These two additional rationales overlap somewhat. Of course, the state of race relations has a direct effect on the lives of racial minorities. Moreover, Professor Dorf nicely illustrates the overlap by describing O'Connor's departure from Powell's opinion as "reject[ing] the requirement that an affirmative action program be justified only by its internal effects. . . Education, she recognized, is not an end in itself; it is preparation for the future, and universities could consider that fact." See Dorf, supra note 9 (emphasis added). Under Dorf's conceptualizaton, both diversity's benefits for society and diversity's benefits for racial minorities would fall under education's "external" effects. I choose to draw a different line because I think additional delineation within diversity's external effects is crucial to understanding Grutter's significance.

42. See also Karst, supra note 6, at 61 ("No longer is the Court limiting its compelling-stateinterest discussion to the educational experience in the classrooms and on the campuses. Now the Court has highlighted the nation's compelling interest in integrated leadership of our institutions.").

There is, of course, some overlap between the first and second rationales. O'Connor argued that diversity benefits individuals by preparing them for their professional and social lives. Grutter, 539 U.S. at 330 (stating that the university's amici show not only that there are "the educational benefits that flow from student body diversity" but also that "numerous studies show that student body diversity promotes leaming outcomes, and "better prepares students for an increasingly diverse workforce and society and better prepares them as professionals"'). This also benefits society by making these people more effective workers and more able citizens. Universities believe they have an interest in such societal development. See, e.g., Brief of Harvard Univ. et al. as Amici Curiae Supporting Respondents at 10, Grutter v. Bollinger, 539 U.S. 306 (2003) (No. 02-241), Gratz v. Bollinger, 539 U.S. 244 (2003) 
instrumental rationale for affirmative action, the Court relied in large part on amicus briefs from corporate America and retired military officers. Corporations, O'Connor recognized, "have made clear that the skills needed in today's increasingly global marketplace can only be developed through exposure to widely diverse peoples, cultures, ideas, and viewpoints." ${ }^{\prime 43}$ And O'Connor noted that retired high-ranking military officers argued in their brief, in language quoted by the Court, that "a 'highly qualified, racially diverse officer corps .... is essential to the military's ability to fulfill its princip[al] mission to provide national security." "44 "These benefits," according to O'Connor, "are not theoretical but real."

At first glance, it may appear that $O^{\prime}$ Connor's invocation of these benefits not only went beyond Powell's Bakke opinion but implicitly overruled it. After all, Powell stated in Bakke that remedying societal discrimination is an impermissible rationale for affirmative action. ${ }^{46}$ Powell clarified this position in his plurality opinion in Wygant v. Jackson Board of Education, writing that "[s]ocietal discrimination, without more, is too amorphous a basis for imposing a racially classified remedy." strong supporter of affirmative action like Justice Ruth Bader Ginsburg had previously recognized that Powell's Bakke opinion "dismissed entirely the

(No. 02-516) ("Amici have a special interest in this pair of cases stemming from their distinctive responsibility, sincc colonial times, to educate leaders in all walks of life.").

43. Grutter, 539 U.S. at 330-31 (citing Brief for Amici Curiae 65 Leading American Businesses in Support of Respondents at 5, Grutter (No. 02-241), Gratz (No. 02-516); Brief of General Motors Corp. as Amicus Curiae in Support of Respondents at 3-4, Grutter (No. 02-241), Gratz (No. 02-516)).

44. Id. at 331 (quoting Consolidated Brief of Lt. Gen. Julius W. Becton, Jr. et al. as Amici Curiae in Support of Respondents at 5, Grutter (No. 02-241), Gratz (No. 02-516)). The Justices referred to this brief repeatedly during oral argument. Justice Stevens, in a subsequent speech to the Chicago Bar Association, singled out the military brief as "very powerful." According to Stevens, it "explained that the interest in an intcgrated officer corps is an unquestionably compelling interest and not just to even things out but it made for a better functioning military when the officer corps was spread across racial lines just as the enlisted personnel were." Michael B. Hyman, Editor's Briefcase, 17 CBA ReCord 6 (2003); see also infra Part III.C.

45. Grutter, 539 U.S. at 330.

46. Regents of the Univ. of Cal. v. Bakke, 438 U.S. 265, 307 (1978) (opinion of Powell, J.) ("The State certainly has a legitimate and substantial interest in ameliorating, or eliminating where feasible, the disabling effects of identified discrimination. ... [But w]e have never approved a classification that aids persons perceived as members of relatively victimized groups at the expense of other innocent individuals in the absence of judicial, legislative, or administrative findings of constitutional or statutory violations."). A related instrumental rationale rejected by Powell is that the affirmative action program for Davis's medical school may "improv[e] the delivery of health-care services to communities currently underserved." $I d$. at 310 . About this, Powell wrote:

It may be assumed that in some situations a State's interest in facilitating the health care of its citizens is sufficiently compelling to support the use of a suspect classification. But there is virtually no evidence in the record indicating that petitioner's special admissions program is either needed or geared to promote that goal.

Id.

47. Wygant v. Jackson Bd. of Educ., 476 U.S. 267, 276 (1986) (plurality opinion). 
state's remediation rationale, maintaining that a single medical school could not attempt to redress societal discrimination."

However, Professor Jack Greenberg has described how O'Connor's Grutter opinion is future oriented and thus different in kind from what Powell precluded:

[A]ffirmative action as a remedy for societal discrimination is not the same as Justice O'Connor's thesis, which does not refer to societal discrimination at all. It refers to social conditions, some of which did and some which did not result from discrimination. Her eye is on the condition of society and what affirmative action can do to help fix it, not what caused the condition. ${ }^{49}$

As such, O'Connor's opinion did not overrule Powell's aversion to affirmative action as remedying societal discrimination. Indeed, Powell recognized in Bakke that society as a whole might be better off with affirmative action. Attorney John Payton, counsel for the University of Michigan in Grutter and Gratz, even concluded his oral argument before the Court by quoting the following sentence by Powell in Bakke: "[I]t is not too much to say that the 'nation's future depends upon leaders trained through wide exposure' to the ideas and mores of students as diverse as this Nation of many peoples." $" 50$

However, Professor Greenberg recognized that the above sentence "does not necessarily contemplate the presence of both blacks and whites among the nation's leaders, only that the leaders, who might all be white, should be attuned to a diversity of ideas and mores." ${ }^{11}$ Bakke gives some societal reasons for diversity, but the language used by Powell focuses on the benefits of "wide exposure" that accrue to those studying at these elite institutions. O'Connor strengthened Powell's hint of societal benefits, Greenberg noted, by "structur[ing] her argument so that preparation for the world beyond graduation has the constitutional protection of being a subset of academic freedom." 52 In Bakke, academic freedom only concerned the control of admissions standards to choose whom to educate. Now, under Grutter, academic freedom enables the university to do what it feels is good for society.

Indeed, some of the benefits O'Connor's opinion had in mind accrue to the students for society. That is, society benefits from students who

48. Ruth Bader Ginsburg \& Deborah Jones Merritt, Affirmative Action: An International Human Rights Dialogue, 21 CARDozo L. Rev. 253, 265 (1999).

49. Jack Greenberg, Diversity, the University, and the World Outside, 103 COLUM. L. REv. 1610, $1621(2003)$.

50. Transcript of Oral Argument at 48-49, Gratz v. Bollinger, 539 U.S. 244 (2003) (No. 02-516) (quoting Bakke, 438 U.S. at 313 (opinion of Powell, J.) (quoting Keyishian v. Bd. of Regents, 385 U.S. 589,603 (1967)).

51. Greenberg, supra note 49 , at 1618 .

52. Id. at 1619 . 
leave school as better citizens. ${ }^{53}$ As O'Connor wrote, "[w]e have repeatedly acknowledged the overriding importance of preparing students for work and citizenship, describing education as pivotal to 'sustaining our political and cultural heritage' with a fundamental role in maintaining the fabric of society." 54 Additionally, student body diversity "helps to break down racial stereotypes," and "diminishing the force of such stereotypes is both a crucial part of the Law School's mission, and one that it cannot accomplish with only token numbers of minority students." 56 In short, it is good for society to have better prepared and more tolerant citizens making up its "fabric." A university has the academic freedom to civically educate students to be good future citizens, and it is a compelling interest for it to do so. ${ }^{57}$

Grutter looked approvingly at the broad societal benefits from affirmative action. Corporate America and retired military leaders told the Court that affirmative action is good for society (and for them). O'Connor agreed and said that developing good citizens is a benefit that flows from affirmative action and fits within a university's social role. All of this goes beyond the "educational benefits of diversity" interest articulated by Powell that supposedly is all that O'Connor "endorse[d]." ${ }^{58}$ But O'Connor put forth even more reasons that, together with the preceding paragraphs, establish why diversity's benefits for society motivated the Court to decide the way it did in Grutter. O'Connor noted that diversity in higher education benefits society by fostering democratic legitimacy and an America that is "one Nation." 59 Both are societal goals for diversity-and ambitious ones at that - but they also point the way to how diversity may benefit not only whites and society at large, but also racial minorities.

53. See also Martha C. Nussbaum, Cultivating humanity: A Classical Defense of REFORM IN LIBERAL EDUCATION 6 (1997) ('The new emphasis on 'diversity' in college and university curricula is above all a way of grappling with the altered requirements of citizenship, an attempt to produce adults who can function as citizens not just of some local region or group but also, and more importantly, as citizens of a complex interlocking world.").

54. Grutter v. Bollinger, 539 U.S. 306, 331 (2003) (quoting Plyler v. Doe, 457 U.S. 202, 221 (1982)); see also James O. Freedman, Liberal Education and the Public Interest 57 (2003) ("Liberal education urges upon us a reflectiveness, a tentativeness, a humility, a hospitality to other points of view, a carefulness to be open to correction and new insight, that can mitigate [social] tendencies toward polarity, rigidity, and intolerance.").

55. Grutter, 539 U.S. at 333.

56. Id.

57. That said, it seems clear that the particular societal goods at stake-and the Court's endorsement of them-tipped the scales in favor of deferencc to the institution's academic freedom. If a public university saw its goal as producing a white leadership class with citizens civically trained to stcreotype racial minorities and incite racial animus, the Court surely would not be so deferential to academic freedom. While doctrinally the society-oriented diversity rationale springs from Powell's original "academic freedom" argument, O'Connor presumably accepted these societal goods themselves as compelling.

58. See Grutter, 539 U.S. at 325, 343.

59. Id. at 332 . 


\section{Diversity's Benefits for Racial Minorities}

The third diversity rationale in Grutter is the value of diversity for racial minorities. As O'Connor wrote, "effective participation by members of all racial and ethnic groups in the civic life of our Nation is essential if the dream of one Nation, indivisible, is to be realized." "60 "[E]ffective participation" is "essential" to realizing this dream, and schools help supply - and may be the primary source of - the means to this end. Despite this general language about members of "all" racial and ethnic groups "effective[ly] participat[ing],"61 O'Connor was referring in particular to racial and ethnic minority groups whose members continue to be largely absent from this sort of robust civic life. By situating Grutter in the famous line of civil rights cases that concern the access of racial minorities to an equal education, O'Connor emphasized that education enables effective civic participation and is a path-if not the path-to leadership. She quoted Brown v. Board of Education to show that the Court "has long recognized that "education... is the very foundation of good citizenship." "62 She also quoted the "proving ground" language from Sweatt v. Painter, ${ }^{63}$ and she cited statistics that indicate that law schoolsparticularly the most highly selective law schools-account for a large share of the country's political leaders..$^{64}$ By using such language and invoking these landmark cases in this way, O'Connor clearly and profoundly illustrated how affirmative action benefits racial minorities, going far beyond Powell's Bakke rationale in the process.

Of course, "effective participation" by members of racial minorities benefits society as well as those minorities, but O'Connor also seems to have been concerned with how to achieve this goal of effective participation. The method she adopted-crucial to an understanding of how the Court embraces the rationale of diversity's benefits for racial minoritiesis embedded in the opinion's most important sentence: "In order to cultivate a set of leaders with legitimacy in the eyes of the citizenry, it is necessary that the path to leadership be visibly open to talented and qualified individuals of every race and ethnicity." ${ }^{965}$

The nature of O'Connor's concern with "legitimacy" may be deceiving. At first glance, it seems to suggest that the integration of Americathe effective participation of everyone - is necessary for democratic legitimacy. Legitimacy as such (a sort of "de facto" legitimacy) is certainly a persuasive societal goal, but under this conception of legitimacy as

\footnotetext{
60. Id. (emphasis added).

61. Id.

62. Id. at 331 (quoting Brown v. Board of Educ., 347 U.S. 483, 493 (1954)).

63. 339 U.S. 629,634 (1950) (describing the law sehool as "the proving ground for legal learning and practice").

64. See Grutter, 539 U.S. at 332.

65. Id.
} 
integration, why would it be important to know what is legitimate "in the eyes of the citizenry"? Alternatively, O'Connor's focus on the "eyes of the citizenry" may suggest that by "legitimacy" O'Connor refers merely to "public confidence," whether based in fact or not. But under that conception, why did O'Connor discuss "cultivat[ing] a set of leaders" as the project at issue? ${ }^{66}$ The "cultivat[ion]" of leaders implies more than setting up a mere façade of success. In short, neither understanding of this important sentence seems complete; neither one seems to answer why O'Connor used and phrased it the way she did.

While democratic legitimacy is a worthy societal goal, it is important to remember that Grutter is about affirmative action in higher education. O'Connor was concerned with the "[e]ffective participation" of racial minorities, meaning those who historically have been excluded or absent from such "effective" participation. O'Connor's method of achieving this "effective participation" is by a "visibly open" path to leadership. ${ }^{67}$ The benefit of a "visibly open" path suggests how affirmative action benefits racial minorities. It is not only important for the path to exist; the path must also be visible. This language of visibility at first seems to give credence to the argument that affirmative action promotes mere "aesthetics"- that is, that such policies are designed to make society look diverse and integrated (perhaps as a salve for white guilt), even if it is not. But that would not capture the potential for "visibility" in this version of legitimacy. Rather, legitimacy depends not only on society at large viewing minorities' path to leadership and concluding that society is legitimate, but also on people outside of college - specifically, younger racial minorities-being able to see themselves years from today, and thus view their own futures with hope and work toward a now more realistic goal. As such, the beneficiaries of affirmative action under O'Connor's rubric include racial minorities themselves, for having minorities in visible positions of power means that the access to effective participation and potential for leadership is, to borrow a phrase, not merely theoretical but real. ${ }^{68}$ Affirmative action policies increase this visibility, and that in itself is good because it helps achieve the "cultivat[ion]" of leaders O'Connor had in mind. ${ }^{69}$

Thus, even beyond their effects on classroom dynamics or society at large, the Court has made a case for how affirmative action policies in higher education help racial minorities. Similarly, the idea of achieving a "critical mass"70 of minority students can be understood not only as helping

66. Cf. id.

67. Id.

68. Cf. id. at 330 .

69. Id. at 332; see also Willifam G. Bowen \& Derek. BoK, The Shape of The River: LongTerm Consequences of Considering Race in College and University Admissions 283 (1998).

70. See Grutter, 539 U.S. at 318-19, 333. 
the majority race, which then improves its treatment of minorities; ${ }^{71}$ the existence of a critical mass can also support the experience of racial minorities themselves by not abandoning them in the vast and unfamiliar sea of majority and privilege. With a critical mass, individual members of minority groups do not have to feel like spokespeople; rather, each person can go to school as an equal without special responsibilities or burdens. With a critical mass, individual minority students do not stick out of the crowd as much, so one need not worry as much that the worth of his or her race in others' eyes is dependent solely on one's own performance.

But more importantly, the "critical mass" idea can also be seen as a necessary condition for achieving a "visibly open" path to leadership. ${ }^{72} \mathrm{~A}$ critical mass is good not only for its benefits to enrolled minority students; it is necessary for its visibility to people of color not at the educational institution. ${ }^{73}$ A critical mass is necessary for future role-modeling to be effective- - so that there will be enough racial minorities in leadership positions to be visible to young minorities. ${ }^{74}$ One may argue that the Court has previously rejected the role-model justification; indeed, O'Connor seems to be overruling the earlier Wygant opinion in this regard..$^{75}$ However, her opinion in the subsequent case of Richmond v. J. A. Croson $\mathrm{Co}^{76}$ noted that

71. O'Connor noted that former Michigan Law Professor Kent Syverud's testimony indicated "that when a critical mass of underrepresented minority students is present, racial stereotypes lose their force because nonminority students learn there is no 'minority viewpoint' but rather a variety of viewpoints among minority students." Id. at 319-20 (internal quotation marks removed).

72. Although some may question whether O'Connor herself viewed the "critical mass" concept in precisely this way, this effect of a critical mass of minority students in higher education is necessary for cultivating a renewing set of leaders - that is, it is necessary for achieving a populated path to leadership.

73. To continue the portrait analogy, these are people in neither the "Before" portrait nor the "After" one. See supra note 23 and accompanying text.

74. Similarly, Richard Posner has commented that "[a]nyone who was serious about the "role model' point would want the minorities to be represented in the professions in inverse proportion to their percentage of the population," in order to make the minority role models visible. Richard A. Posner, The DeFunis Case and the Constitutionality of Preferential Treatment of Racial Minorities, 1974 Sup. CT. REv. 1, 17 n.35 (1974) ("Suppose Indigos were 10 percent of the population and Ultramarines only 1 percent. If the percentage of Indigo lawyers was raised to 10 to supply adequate role models for young Indigos, the percentage of Ultramarine lawyers should also be raised to 10, for only in that way will the Ultramarine role models be visible to young Ultramarines.") (emphasis added). Note that Posner was writing as a critic of the "role model" argument. See id. at 17 ("The "role model' argument is ... ad hoc and conjectural... There is no basis for requiring proportional representation.").

75. See Wygant v. Jackson Bd. of Educ., 476 U.S. 267, 275 (1986) ("[T] The role model theory employed by the District Court has no logical stopping point."). The method employed by the Court of Appeals for finding the need for role models may have been part of the hang-up in Wygant. See id. at 274 ("The court discerned a need for more minority faculty role models by finding that the percentage of minority teachers was less than the percentage of minority students."). However, the Court criticized the role-model justification with a more potent charge: "Carried to its logical extreme, the idea that black students are better off with black teachers could lead to the very system the Court rejected in Brown v. Board of Education." Id. at 276 (citation omitted).

76. 488 U.S. 469 (1989). 
[t]he role model theory employed by the lower courts failed [in Wygant] for two reasons. First, the statistical disparity between students and teachers had no probative value in demonstrating the kind of prior discrimination in hiring or promotion that would justify race-based relief. ... Second, because the role model theory had no relation to some basis for believing a constitutional or statutory violation had occurred, it could be used to "justify" race-based decisionmaking essentially limitless in scope and duration. $^{77}$

Grutter, as opposed to Wygant, is not about "prior" discrimination or violations, but is future oriented. That does not entirely answer O'Connor's earlier concern about race-based action without a logical end-point, but the Grutter rationale's focus on the future may have been enough. And O'Connor even added an end-point in Grutter: twenty-five years. ${ }^{78}$ But regardless of Wygant's future precedential value, O'Connor seemed to endorse and rely on the role-model argument in Grutter. The "cultivat[ion]" of "a set of leaders"79 depends on visibility, which the people of color who have access to and then graduate from these elite universities will more likely provide.

Therefore, O'Connor's visibility language can be about more than democratic legitimacy. But her aim may be even more ambitious than creating role models and engendering hope. Peter Schuck dcscribes the claim of the role-model argument as "[a] variant of the anticaste rationale." Affirmative action, under this variant,

is effective in producing a cadre of black professionals who can form a nucleus of group leaders and serve as role models for other members of the group, especially the young who need to have high aspirations and confidence that others have succeeded despite their common legacy of group disadvantage. This rationale . . . applies most strongly to the domain of higher education. ${ }^{81}$

Affirmative action, then, not only helps those minority students who are admitted, and not only helps racial minorities outside the university who are watching and hoping. It is also beneficial to racial minorities generally.

It is beyond the scope of this Comment to fully analyze the anticaste rationale and its ultimate tenability under O'Connor's opinion, but suffice it to say that the most ambitious reading of O'Connor's opinion is as follows: she believed diversity in higher education admissions can create a cadre of future graduates-group leaders and role models for the young-

77. Id. at 497-98 (plurality opinion) (citations omitted). Note that this part of O'Connor's opinion only spoke for three other Justices: Rehnquist, White, and Kennedy.

78. But see infra Conclusion.

79. Grutter v. Bollinger, 539 U.S. 306, 332 (2003).

80. Schuck, supra note 40 , at 157.

81. Id. at $157-58$. 
who can help eliminate the pernicious system of racial caste. But even if one prefers to give a less ambitious meaning to the decision, the text of O'Connor's opinion, with its "critical mass," "effective participation," "training ground," and "visibility" language, makes a strong case that the diversity rationale is meant to benefit not only whites at universities and society at large, but also racial minorities.

\section{Diversity Revolution?}

In an interview with the Chicago Tribune the day after the Michigan decisions were announced, Justice O'Connor both acknowledged and attempted to minimize the changes she made to Bakke. Asked whether Justice Powell would have joined her Grutter opinion, she said she was unsure. The article describes O'Connor's response:

"He'd probably say, 'Well, you may have made too much about what I had to say," O'Connor said, laughing at the thought. "I don't know. It was fairly consistent with the view he expressed in Bakke. If he had been here, whether he would've gone along with all of the nuances and declarations, it's hard to say." $" 82$

It is possible that if Powell were on the Court when the Michigan cases were decided, he would have agreed with O'Connor's Grutter opinion, especially after reading Grutter's record number of amicus briefs and having the benefit of experience and the torrent of legal commentary under twenty-five years of Bakke. Alas, we will never know. What is clear is that while "diversity" as a rationale for university affirmative action has survived and has gone from one to six votes, ${ }^{83} \mathrm{O}^{\prime}$ Connor's "nuances and declarations" have revolutionized the diversity rationale. The next sections examine some implications for the new diversity interest(s) on the calculus of courts' affirmative action decision making. Doing so will reveal why it is so significant that Grutter has gone beyond Bakke.

II

\section{The New Calculus and Justice Thomas}

Many supporters of affirmative action will no doubt welcome Grutter's attention to diversity's benefits for society and for racial minorities. By going beyond Bakke, the Court has articulated a broader diversity interest (or, rather, three diversity interests ${ }^{84}$ ) with more "nuances and declarations." 85 But opponents of affirmative action-especially those whose opposition springs from the belief that affirmative action harms racial

82. Jan Crawford Greenburg, $O^{\prime}$ Connor Voices Hope for Day Affirmative Action Not Needed, ChI. Trib., June 25, 2003, at 1.

83. See supra note 3.

84. See infra Part II.D.

85. Greenburg, supra note 82 , at I. 
minorities-should not be devastated by O'Connor's strong language endorsing diversity's benefits for minorities. Her reformulation of the diversity rationale has created an opening for critics that they lacked under Bakke. Indeed, the overall diversity interest in Grutter may actually be weaker and more vulnerable than the one in Bakke. This Part examines the door O'Connor created in her opinion for the Court, who is already attempting to walk through the door, and how this is a new calculus for litigation involving affirmative action in higher education.

\section{A. Strict Scrutiny's "Compelling Interest" Requirement}

Grutter, according to the Court, was decided under strict scrutiny. ${ }^{86}$ O'Connor wrote that "strict scrutiny is designed to provide a framework for carefully examining the importance and the sincerity of the reasons advanced by the governmental decisionmaker for the use of race in [a] particular context." related, determining that an interest is a "compelling interest" depends on establishing both of them. For a court to find a "compelling interest," it must adopt both the policy argument that an interest is "important" enough and the evidentiary argument that this policy is not rooted in bad motives. ${ }^{88}$ This means that for an opponent of a policy subject to strict scrutiny to prevail, a court need only find that the use of race, for example, is either unimportant or insincere (meaning done with illegitimate motives in mind). ${ }^{89}$

What, then, does it mean for a court to examine whether a governmental policy is sufficiently "compelling" or "important"? Peter Rubin delineates two purposes served by the requirement of a "compelling governmental interest":

First, it permits a reviewing court to make a determination concerning the importance of the government's goal. Second, the

86. See Grutter v. Bollinger, 539 U.S. 306, 326 (2003). The dissenting Justices would disputc whether the majority in fact employed strict scrutiny, but the point here is not whether the scrutiny was in fact "strict" in the instant case or how "strict" it will be in the future, but that the Court maintained that "strict scrutiny" was the standard for its decision.

87. Id. at 327. The "sincerity" inquiry is sometimes referred to as a "smok[ing] out" of illegitimate motives. $C f$. Richmond v. J.A. Croson Co., 488 U.S. 469, 493 (1989).

88. Goodwin Liu sets forth this framework:

[T]he question of whether educational diversity is a "compelling interest" really consists of two distinct questions: (1) whether, as a substantive matter, diversity is sufficiently important to justify the use of race, and (2) whether, as a factual matter, a university's stated interest in diversity is genuine. The first requires a policy argument; the second requires an elaboration of evidentiary criteria.

Goodwin Liu, Affirmative Action in Higher Education: The Diversity Rationale and the Compelling Interest Test, 33 HARV. C.R.-C.L. L. REv. 381, 410 (1998) (citation omitted).

89. See id. "Under current affirmative action law, there are two ways a court could determine that a goverumental interest is not 'compelling': (1) by denying the substantiality of the stated interest, as in Bakke and Wygant, or (2) by rejecting the sincerity of the stated interest, as in Croson."). 
use of the "compelling" label incorporates the idea that the costs of using a particular type of classification are great enough that the achievement even of most legitimate governmental purposes will not outweigh the harm wrought by use of the classification. ${ }^{90}$

These two purposes overlap almost completely in a functional sense. Strict scrutiny requires the Court to balance benefits and harms to determine the "importance" of a governmental interest. To say something is "good" or "important" for some group X is to say this "good" policy is made up of benefits for $\mathrm{X}$ that outweigh any harms to $\mathrm{X}$ if any such harms exist. Grutter is significant in that it considers three rationales-benefits to $\mathrm{X}$ (white people and the university) as well as to $\mathrm{Y}$ (society at large) and $\mathrm{Z}$ (racial minorities) ${ }^{91}$ Fortunately for affirmative action's opponents and unfortunately for its supporters, whether an interest is "compelling" cannot end with a consideration of a policy's benefits. As the next Section shows, the calculus is different with new inputs, because the harms to $\mathrm{Y}$ and $\mathrm{Z}$, if any exist, are now in play.

\section{B. A New Question: Is Diversity "Compelling” for Racial Minorities?}

Bakke was about diversity for whites (and for the university). ${ }^{92}$ Justice Powell characterized the university as a gatekeeper to itself and as a pedagogically improved educator of better-trained whites. His concern was whether UC Davis's admissions policy was fair to those whites excluded due to their skin color-whether a justification could be found and a narrowly-tailored admissions program could be implemented to counter this harm. A justification was found: the educational benefits of diversity, and the kind of program Powell stated could be implemented to further this interest was along the lines of the Harvard "plus" plan. ${ }^{93}$ As a result,

90. Peter J. Rubin, Reconnecting Doctrine and Purpose: A Comprehensive Approach to Strict Scrutiny after Adarand and Shaw, 149 U. PA. L. Rev. 1, 14 (2000). Rubin does not neglect the "smoking out" purpose of strict scrutiny; rather, he situates it in the "narrow tailoring" prong. See id. ("A narrow tailoring inquiry can help to 'smoke out' illegitimate purposes by demonstrating that the classification does not, in fact, serve the stated, legitimate purpose.").

91. See generally supra Part 1.

92. See supra Part 1.A.

93. See Regents of the Univ. of Cal. v. Bakke, 438 U.S. 265, 316-18 (1978). Powell described the relevant features of the Harvard plan:

In such an admissions program, race or ethnic background may be deemed a "plus" in a particular applicant's file, yet it does not insulate the individual from comparison with all other candidates for the available seats. The file of a particular black applicant may be examined for his potential contribution to diversity without the factor of race being decisive....

This kind of program trcats each applicant as an individual in the admissions process. The applicant who loses out on the last available seat to another candidate reeeiving a "plus" on the basis of ethnic background will not have been foreclosed from all considcration for that seat simply because he was not the right color or had the wrong surname. It would mean only that his combined qualifications, which may have included similar nonobjective factors, did not outweigh those of the other applicant.

Id. at 317-18. 
Powell did not begin to grapple with either the benefits or the harms to racial minorities from an affirmative action policy.

Justice O'Connor, by contrast, described universities as gatekeepers to and engineers of a diverse society and wrote in Grutter about the benefits of affirmative action to racial minorities. But she only wrote about benefits. O'Connor never grappled with the possibility that costs may be borne by racial minorities. ${ }^{94}$ Perhaps $O^{\prime}$ Connor assumed that her opinion's forceful expression of the benefits showed that the costs meant nothing. But there is no evidence the costs were even dealt with-not even a footnote acknowledging the existence of an argument that racial minorities might suffer some harm.

The present effect of Grutter is that it constitutionalizes certain inputs (especially those of the harm-to-minorities variety) for the balancing of benefits and harms in evaluating affirmative action in higher education. After Bakke, in which affirmative action's impact on minorities was not part of Powell's diversity rationale (since diversity was "compelling" because of its benefits for whites and the university), if one were to argue that affirmative action harms racial minorities, he may be met in all doctrinal fairness with the rejoinder, "Why are you talking about minorities? Diversity wins because whites benefit (i.e., they benefit more than they are harmed). The only way diversity can lose is if whites are harmed (i.e., they are harmed more than they are benefited)." O'Connor in Grutter, by contrast, put forth an argument that diversity is good for racial minorities. But to say an affirmative action plan is good for minorities logically means that such a plan is not bad for minorities. If evidence exists that affirmative action is bad for minorities, that evidence is now relevant. Under this new calculus, with diversity's benefits for racial minorities part of the Court's Grutter rationale, the costs of affirmative action in higher education for minorities have become constitutional arguments that have a place in equal protection analysis.

O'Connor thereby created an opening when she formulated the diversity interest as she did. Grutter legitimizes the weighing of the benefits for and harms to racial minorities from affirmative action in university admissions. ${ }^{95}$ But since O'Connor did not consider the harms, the door of

94. Indeed, O'Connor's concern for costs was about the costs to whites. She wrote that " $[t] 0$ be narrowly tailored, a race-conscious admissions program must not "unduly burden individuals who are not members of the favored racial and ethnic groups." Grutter v. Bollinger, 539 U.S. 306, 34I (2003) (quoting Metro Broad., Inc. v. FCC, 497 U.S. 547, 630 (I990) (O'Connor, J., dissenting)). Her concern in Grutter, like Powell's in Bakke, was for "rejected applicant[s]." See id. Indeed, the Court "agree[d with Bakkel that, in the context of its individualized inquiry into the possible diversity contributions of all applicants, the Law School's race-conscious admissions program does not unduly harm nonminority applicants." Id. (emphasis added).

95. At the very least, an assertion of the harms to minorities has more traction under Grutter than it would have had under Bakke. My argument, however, goes further-it is that Grutter gives such a claim the legal opening that it previously lacked. See also infra Parts 1I.C.2-3. 
benefit-harm balancing for racial minorities was never sealed shut. Indeed, the door may be creaking open.

Lo and behold, someone is at the door. It is Justice Thomas.

\section{Justice Thomas at the Door. May He Enter?}

\section{Thomas in Grutter}

Justice Thomas approached Grutter's new calculus with gusto. Thomas began his twenty-nine-page dissenting opinion with a quotation from Frederick Douglass, saying in part: "What I ask for the Negro is not benevolence, not pity, not sympathy, but simply justice.... All I ask is, give him a chance to stand on his own legs! Let him alone!... [Y] our interference is doing him positive injury." described the positive injury caused by the admissions policy by asking, "Who can differentiate between those who belong and those who do not?' ${ }^{\prime 97}$ When the majority of blacks are admitted because of affirmative action, Thomas wrote,

all are tarred as undeserving. This problem of stigma does not depend on the determinacy as to whether those stigmatized are actually the 'beneficiaries' of racial discrimination. When blacks take positions in the highest places of government, industry or academia, it is an open question today whether their skin color played a part in their advancement. ${ }^{98}$

He added that "[ $t]$ he question itself is the stigma-because either racial discrimination did play a role, in which case the person may be deemed 'otherwise unqualified,' or it did not, in which case asking the question itself unfairly marks those blacks who would succeed without discrimination." $" 99$

The crux of his issue with the majority's opinion is this: "I must contest the notion that the Law School's discrimination benefits those admitted as a result of it." 100 The question is the stigma, and the stigma is the "positive injury." This injury is a harm to racial minorities caused by affirmative action, according to Justice Thomas, and this harm is an input into the new calculus.

96. Grutter, 539 U.S. at 349-50 (Thomas, J., eoncurring in part and dissenting in part). For criticisms of Thomas's use of the Douglass quotation, see Derrick Bell, Learning from Living: The University of Michigan Affirmative Action Cases, JURIST, Sept. 5, 2003, http:/jurist.law.pitt.edu/forum/symposium-aa/bell.php; Paula C. Johnson, Jam Tomorrow and Jam Yesterday: Reflections on Grutter, Gratz and the Future of Affirmative Action, JuRIST, Sept. 5, 2003, http:/jurist.law.pitt.edu/forum/symposium-aa/johnson.php (calling the quotation's use "disingenuous").

97. Grutter, 539 U.S. at 373 (Thomas, J., eoneurring in part and dissenting in part).

98. Id.

99. Id.

100. Id. at 371 . 
Thomas stood at the door O'Connor created carrying a stigma argument, but he was not met at the doorway with a hospitable welcome. Instead, Thomas's Grutter dissent was met with an immediate flood of anger and derision. To many affirmative action enthusiasts-and even some dispassionate observers ${ }^{101}$-the opinion (specifically, Thomas's arguments concerning racial stigma) seemed like an angry and personal rant unsupported by legal reasoning. ${ }^{102}$ In a much-discussed editorial, Maureen Dowd, columnist for the New York Times, opined that Thomas "knew that he could not make a powerful legal argument against racial preferences, given the fact that he got into Yale Law School and got picked for the Supreme Court thanks to his race. So he made a powerful psychological argument." 103

Thomas's "positive injury" argument ought to be grappled with more deeply and situated in the legal conversation rather than casually dismissed as an angry rant. ${ }^{104}$ His stigma argument had an unstated but logical invitation to the legal calculus. Dowd could not see through her rage that Thomas's arguments are now legal ones. ${ }^{105}$ She was-and is-not alone. It would be a mistake for affirmative action's supporters to disregard Thomas's opinion, dismissing it as ungrateful and analyzing him poppsychologically rather than examining his opinion. The Thomas opinion presents a bracing case against affirmative action, but more importantly, his opinion sets forth a legal argument about a potential cost to racial minorities from affirmative action: stigmatic harm.

\section{Stigma in Prior Affirmative Action Cases}

Stigma concerns are not new to Supreme Court jurisprudence, but in prior affirmative action cases, stigmatic harm was not a constitutional input. The stigma arguments raised in these earlier affirmative action cases ${ }^{106}$ were substantively different and as such were at times more akin to being perceived - and sometimes were even labeled - as moral arguments.

101. See, e.g., Linda Greenhouse, Context and the Court, N.Y. Times, June 25, 2003, at A1 (commenting that Thomas "took as his text not the briefs but his own life story").

102. See supra note 8.

103. Dowd, supra note 8.

104. To be sure, not every commentator has been dismissive of Thomas's dissent. See, e.g., Angela Onwuachi-Willig, Just Another Brother on the SCT?: What Justice Clarence Thomas Teaches Us About the Influence of Racial Identity, 90 IowA L. REv. 931, 990-96 (2005) (considering Thomas's Grutter opinion within the context of black conservative thought); Mark Tushnet, Clarence Thomas 's Black Nationalism, 47 How. L.J. 323, 327-30, 338-39 (2004) (considering Thomas's Grutter opinion within the context of Thomas's other opinions and their shared strand of black nationalism).

105. Cf. Dowd, supra note 8 ("Other justices rely on clerks and legal footnotes to help with their opinions; Justice Thomas relies on his id, turning an opinion on race into a therapeutic outburst.").

106. For a more detailed case-by-case exegesis of various Justices' opinions conceming stigma and affirmative action since the case of DeFunis $v$. Odegaard, see Andrew F. Halaby \& Stephen $R$. McAllister, An Analysis of the Supreme Court's Reliance on Racial "Stigma" as a Constitutional Concept in Affirmative Action, 2 MiCH. J. RACE \& L. 235 (1997). 
At first, stigma had no opening at all, as Powell's Bakke opinion closed the door on stigma arguments. ${ }^{107} \mathrm{~A}$ majority of Justices said race could be considered as a factor in admissions decisions, but Powell dismissed stigma as a concern. ${ }^{108}$ Powell mentioned thc term "stigma" in response to the separate opinion of Justice Brennan et al. in order to reject a test that would condemn programs with stigma that is "malevolent."109 Powell put forth strict scrutiny, rather than a "less restrictive" 110 reading of the Equal Protection Clause, because his concern was not for the intentions motivating the racial classification and thus was not interested in using malevolent stigma as a "less restrictive" test; he cared about those in the racial majority not being burdened."11

Later in Bakke, Powell described three problems he saw with racial preferences, the first two expressing concern about their impact on minorities:

First, it may not always be clear that a so-called preference is in fact benign. Courts may be asked to validate burdens imposed upon individual members of a particular group in order to advance the group's general interest. Nothing in the Constitution supports the notion that individuals may be asked to suffer otherwise impermissible burdens in order to enhance the societal standing of

107. The first case to reach thc Supremc Court dealing with the constitutionality of affirmative action was DeFunis v. Odegaard, 416 U.S. 312 (1974). Like Grutter, it was a case about a law school's admissions policy. Although a majority of the Court disposed of the claim as moot, Justice William $O$. Douglas dissented and was the first Supreme Court Justice to write on the merits of affirmative action in education admissions programs. His opinion mentioned the stigma argument: "A segregated admissions process creates suggestions of stigma and caste no less than a segregated classroom, and in the end it may produce that result despite its contrary intentions." DeFunis, 416 U.S. at 343 (Douglas, J., dissenting). Douglas presented the concept of stigma, but his opinion has no precedential value.

108. See Regents of the Univ. of Cal. v. Bakke, 438 U.S. 265, 294 n.34 (1978) (opinion of Powell, J.) ("In the view of [Brennan, White, Marshall, and Blackmun], the pliable notion of 'stigma' is the crucial element in analyzing racial classifications. The Equal Protection Clause is not framcd in terms of 'stigma.' Certainly the word has no clearly defined constitutional meaning. It reflects a subjective judgment that is standardless.....Moreover, [Brennan, White, Marshall, and Blackmun] offer no principle for dcciding whether preferential classifications reflect a bcnign remedial purpose or a malevolent stigmatic classification, since they are willing in this case to accept mere post hoc declarations by an isolated state cntity-a medical school faculty-unadorned by particularized findings of past discrimination, to cstablish such a remedial purpose.") (citation omitted); see also Halaby \& McAllister, supra notc 106, at 254 \& n.83 (characterizing the sentences of Justice Powell's decision before the ellipsis above as "disparag[ing] stigma's value in any analysis of race-based classifications").

109. Bakke, 438 U.S. at 294 n.34 (opinion of Powell, J.). This is clear by reading the sentence lcading to footnote 34: "Petitioner urgcs us to adopt for the first time a more restrictive view of the Equal Protection Clause and hold that discrimination against members of the white 'majority' cannot be suspect if its purpose can be characterized as 'benign."' Id. at 294.

110. Cf. supra note 109 .

111. Bakke, 438 U.S. at 294 n.34 (opinion of Powell, J.) ("All state-imposed classifications that rearrange burdens and benefits on the basis of race are likely to be viewed with deep resentment by the individuals burdened. The denial to innocent persons of equal rights and opportunities may outrage those so deprived and therefore may be perceived as invidious."). 
their ethnic groups. Second, preferential programs may only reinforce common stereotypes holding that certain groups are unable to achieve success without special protection based on a factor having no relationship to individual worth. ${ }^{112}$

These are real concerns, but because Powell held that the educational benefits of diversity were the compelling state interest, ${ }^{113}$ they had nowhere to go; there was nothing doctrinally for them to interface with in a balancing of harms and benefits because the only interest in play was diversity for whites and the university. ${ }^{114}$

O'Connor previously mentioned stigma in her opinion in Croson. She wrote that "[c]lassifications based on race carry a danger of stigmatic harm. Unless they are strictly reserved for remedial settings, they may in fact promote notions of racial inferiority and lead to a politics of racial hostility." 115 But there, O'Connor did not speak for the Court, since the part of O'Connor's opinion from which it came only received four votes. ${ }^{116}$ O'Connor said that stigma is one reason to conduct strict scrutiny, but Grutter's version of strict scrutiny curiously did not evaluate the stigma argument-and Grutter was not a "remedial setting[]," but forwardlooking.

In Adarand Constructors, Inc. v. Pena, ${ }^{117} \mathrm{O}^{\prime}$ Connor again discussed stigma, this time writing for a majority of the Court. Responding to Justice Stevens's dissent criticizing the majority for its use of strict scrutiny for both "invidious" and "benign" racial classifications, the majority led by O'Connor cited approvingly Stevens's prior opinions raising the concerns

112. Id. at 298. Powell's third problem with preferences has to do with whites: "[T]here is a measure of inequity in forcing innocent persons in respondent's [Bakke's] position to bear the burdens of redressing grievances not of their making." Id.

113. See supra Part 1.A.

114. Now, of course, with O'Connor relying in part on diversity's benefits for racial minorities (as 1 have shown supra), these concerns ought to carry more weight (and I believe they will; see infra).

115. Richmond v. J.A. Croson Co., 488 U.S. 469, $493-94$ (1989) (plurality opinion). For support, O'Connor cited to Bakke, 438 U.S. at 298 (opinion of Powell, J.) ("[P]referential programs may only reinforce common stereotypes holding that certain groups are unable to achieve success without special protection based on a factor having no relation to individual worth.").

116. Part 111.A of Croson received Justice O'Connor's vote as well as the votes of Chief Justice Rehnquist, Justice White, and Justice Kennedy. Note that the Court in Shaw v. Reno raised the danger of stigmatic harm in the context of an electoral redistricting effort that considered race and cited O'Connor's plurality opinion in Croson in the process. See Shaw v. Reno, 509 U.S. 630, 643 (1993) (citing Croson, 488 U.S. at 493 (plurality opinion)). Although a majority of the Court invoked O'Connor's Croson stigma language and recognized stigma's danger, this invocation is not as significant for this Comment as it might appear at first blush. In other words, stigma has not necessarily had an opening in affirmative action cases since 1993. This is because the stigmatic danger in Shaw is of the more expressive variety. Cf. infra note 194. The stigmatic harm at issue in this Comment is the psychological kind. See generally infra Part 111.A.1. (Additionally, in the education admissions context of affirmative action, there was no opening for considering stigmatic concerns before Grutter, as my discussion earlier in this Comment points out. See supra text at notes 19-28 (describing Bakke's diversity interest as being for whites and the university).)

117. 515 U.S. 200 (1995). 
of stigma and negative stereotyping. For the majority, these prior opinions made a "persuasive case" for strict scrutiny for both types of classifications, for they explained "why 'good intentions' alone are not enough to sustain a supposedly 'benign' racial classification." 18 But while O'Connor this time had a majority of the Court with her, her Adarand opinion is like her Croson language in that stigma was discussed in a contracting case regarding remedying the effects of past discrimination.

Adarand did, however, set the stage for Grutter by making clear that strict scrutiny is concerned with how "compelling" a racial classification is for all affirmative action. The following passage of Justice O'Connor's opinion for the Court in Adarand makes this clear:

[W] henever the government treats any person unequally because of his or her race, that person has suffered an injury that falls squarely within the language and spirit of the Constitution's guarantee of equal protection.... The application of strict scrutiny, in turn, determines whether a compelling governmental interest justifies the infliction of that injury. ${ }^{19}$

Christopher Edley, then a Clinton administration official at work on the "Mend It, Don't End It" affirmative action reforms, reacted to this decision by noting that "[a]fter Adarand, ... many matters previously in the realm of policy choice and prudent judgment were now matters of constitutional analysis. ${ }^{~} 120 \mathrm{He}$ was correct, as strict scrutiny for more areas of policymaking meant that the Court itself would be able to balance benefits and harms in more kinds of cases. Strict scrutiny makes the court more central to examining what, under intermediate scrutiny, would be policy areas with more latitude for elected bodies. ${ }^{121}$

Still, stigma needed a doctrinal opening into the Bakke diversity interest supporting affirmative action in higher education-an opening it still lacked after Adarand.

\section{Thomas in Adarand versus Thomas in Grutter}

Justice Thomas burst onto the Court's affirmative action scene in Adarand. Concurring in part and concurring in the judgment, he wrote separately to state his opinion that there is no "racial paternalism exception to the principle of equal protection." 122 Citing the Declaration of Independence as support, Thomas wrote that " $[t]$ here can be no doubt that

118. Id. at 229 (citing Fullilove v. Klutznick, 448 U.S. 448, 537 (1980) (Stevens, J., dissenting)).

119. Id. at 229-30 (emphasis added).

120. Christopher Edley, Jr., Not All Black and White: Affirmative Action, Race, and American Values 65 (1996).

121. Applying strict scrutiny and focusing on whether an interest is "justifie[d]" gives the Court more room to make policy judgments. 1 take no position in this Comment on whether this is a desirable feature of equal protection analysis or part of the Court's proper institutional role.

122. 515 U.S. at 240 (Thomas, J., concurring in part and concurring in the judgment). 
the paternalism that appears to lie at the heart of this program is at war with the principle of inherent equality that underlies and infuses our Constitution." 123 This, to Thomas, was a constitutional argument, and he offered it to reinforce his belief (and the majority's) that "it is irrelevant whether a government's racial classifications are drawn by those who wish to oppress a race or by those who have a sincere desire to help those thought to be disadvantaged." 124

However, Thomas distinguished the above constitutional concerns from what he then specifically described as "moral" questions. ${ }^{125}$ In the "moral" paragraph, Thomas stated the full force of his stigma argument:

$[T]$ here can be no doubt that racial paternalism and its unintended consequences can be as poisonous and pernicious as any other form of discrimination. So-called "benign" discrimination teaches many that because of chronic and apparently immutable handicaps, minorities cannot compete with them without their patronizing indulgence. Inevitably, such programs engender attitudes of superiority or, alternatively, provoke resentment among those who believe that they have been wronged by the government's use of race. These programs stamp minorities with a badge of inferiority and may cause them to develop dependencies or to adopt an attitude that they are "entitled to preferences." 126

As Thomas recognized, stigma comes not just from the outside; it is also how the person of color feels. But in Adarand, Thomas's argument about stigma and its harm to minorities came, as Thomas himself admitted, under the "moral" part of his overall critique. ${ }^{127}$

\section{Id.}

124. Id.

125. See id. ("These programs not only raise grave constitutional questions, they also undermine the moral basis of the equal protection principle.") (emphasis added).

126. Id. at 240-41.

127. A number of legal scholars in the years after Adarand also characterized the stigma argument as moral or political. See, e.g., Cass Sunstein, Affirmative Action, Caste, and Cultural Comparisons, 97 Mich. L. REV. 1311, 1312 (1999) ("This is not to say that affirmative action policies are a good idea. To be sure, they may have stigmatizing effects on their intended beneficiaries, and they may also increase rather than decrease racial antagonism. But these are essentially political complaints, not constitutional ones." Thus, they are "best heard in legislatures rather than courtrooms."); see also CAss Sunstein, One Case at a Time: Judiclal Minimalism on the Supreme Court 129 (1999) ("Affirmative action programs may well stigmatize their intended beneficiaries. But this form of stigma does not create a constitutional objection."). Curiously, stigma was sometimes classified as political rather than legal as part of a criticism of Thomas's Adarand opinion. See, e.g., Jeffrey Rosen, The Color-Blind Court, 45 AM. U. L. REv. 791, 800-01 (1996) ("The problem with Justice Thomas's (implicit) emphasis on the stigma of caste is that the social meaning of affirmative action is highly contested in contemporary politics. . . In other words, Justice Thomas may or may not be correct, as a policy matter, that the most efficient way of avoiding stigma is to ban affirmative action in all circumstances; but it is odd for a self-styled strict constructionist to impose this contested social judgment on the political branches, rather than letting the political debate take its course."); $c f$. Jed Rubenfeld, Affirmative Action, 107 YaLE L.J. 427, 428 (1997) ("For cxample, the Justices who have found against affirmative action programs repeatedly have done so on the ground that affirmative 
Thomas's "moral" stigma arguments in Adarand were new to the Court; they were generalized ("[t]hese programs stamp minorities ...") and forward-looking. Unfortunately for Thomas, they were up against cases (Croson and Adarand) about specific and past discrimination. And as shown supra, Bakke's articulation of the diversity interest did not provide an opening for a stigma argument. Accordingly, Thomas's new ${ }^{128}$ kind of arguments had to remain "moral" because stigma still did not have an opening to be a constitutional argument.

Until Grutter, that is. Grutter, by contrast, is about university admissions and is forward-looking; the majority spoke in general language about benefits for society and for racial minorities. Thomas's stigma argument, labeled "moral" in Adarand and having no opening under Bakke, now has Grutter's diversity interest (specifically, diversity's benefits for racial minorities) with which it can interface. The costs Thomas brought up in Adarand have thus become constitutional arguments. They are no longer simply "moral"; because of O'Connor's Grutter opinion, stigma-at least that stigma arising from university affirmative action programs ${ }^{129}$-now has a door into the legal debate and can rightly be considered by courts.

\section{The Beginnings of a Stigma Debate: O'Connor's "Visibly Open" Language versus Thomas as Visible}

O'Connor's third diversity rationale - diversity's benefits for racial minorities-and Thomas's challenge are both quite significant. Those who dismiss Thomas's Grutter opinion as a losing argument or indignantly attack it as a mad rant without a basis in the law do not realize that Thomas seemed to recognize the significance of O'Connor's opinion and issued a challenge under it. O'Connor's Grutter majority changed the formula under which affirmative action will be evaluated, and Thomas advocated an input he hopes future courts, examining either specific affirmative action policies or the issue itself, will use in their calculus of the balance of the harms with the interests of the state. According to O'Connor's opinion, affirmative action's effect on racial minorities is a compelling rationale; as a result, along with its benefits to minorities (emphasized by O'Connor),

action threatens inadvertently to entrench racial thinking and to stigmatize minorities. Defenders of affirmative action tend to respond to this assertion by denying the reality of these harms or by arguing that they are outweighed by affirmative action's benefits. But this entire set of arguments, both for and against, is in fact constitutionally irrelevant.") (emphasis added).

128. But see Halaby \& McAllister, supra note 106, at 267 ("Thomas also recognized the strain of stigma that is perhaps closest to that recognized in Plessy and Brown, marking the first time since Justice Douglas's DeFunis dissent that any Justice had taken notice of it. This strain, inferiority-type self-stigma suffered by powerless beneficiaries, differs from the Plessy/Brown strain only in the distributive posture of the stigmatized group: the former refers to beneficiaries while the latter refers to nonbeneficiaries.... [Thomas's] focus on the underlying negative attribution of inferiority and on the group of powerless beneficiaries-minority recipients of affirmative action-is explicit.").

129. See also infra Parts 111.A.2-3. 
affirmative action's harms to racial minorities (emphasized by Thomas) are now also logically part of the calculus for measuring how compelling the state's interest truly is.

Having established that Thomas entered the legal calculus as altered by O'Connor in Grutter, what he actually said turns out to be a significant challenge. Countering the "visibly open" language of the majority, Thomas spoke as a person of color in a position of influence-that is, as one who is visible and is presumably being viewed. The torrent of belittling criticisms of Thomas and his opinion actually helps to undermine the "visibly open" rationale that O'Connor put forth. Clarence Thomas, accused by some of not being authentically or sufficiently black, ${ }^{130}$ is currently the only black Supreme Court Justice-one whose visibility might demonstrate that the path to the Supreme Court is open to future generations ${ }^{131}$ - and he is often ridiculed and dismissed for his "ungrateful" views. ${ }^{132}$ His most dismissive critics help prove his point about stigma, because criticisms of him as an ungrateful minority ${ }^{133}$ both contribute to and reveal the existence of a stigmatic burden. If a black person who dissents from the majority position on affirmative action is therefore somehow ungrateful for what the univcrsity has given him and is no longer seen as authentically black, are racial minorities in the high ranks of society, who under this logic must have gotten there by the grace of the racial majority admitting them to college, only important in that they are visible? Do they ruin the primary benefit of their visibility if they happen to speak up and say the wrong thing? ${ }^{134}$

Moreover, O'Connor's opinion implies that racial minorities' ability to succeed will flow from seeing other racial minorities walk out the gates of the university and succeed in socicty. Thomas's dissent and the reaction

130. Two prominent critical race theorists consider Clarence Thomas to be, in the words of Malcolm X, a "house Negro." See LaWrence \& MATSUda, supra note 26, at 120 (quoting Malcolm X, Message to the Grass Roots, in Malcolm X Speaks 10 (George Breitman ed., 1990)) ("There were two kinds of slaves, the house Negro and the field Negro. The house Negroes-they lived in the house with the master...."); see also id. at 124 (Thomas "has made his career parroting the master's words and doing the master's bidding. The stigma he bears comes with making oneself in the master's image; that is to say, as the master imagines you. This is the most demeaning stigma of all."). They do not even believe he is speaking for himself. See id. at 135 (noting "the peculiar injury that is done and the unique anger that is evoked when a Black man plays the minstrel, acting the part that racist whites have written") (emphasis added). As is evident from the 1997 date of the Lawrence and Matsuda book, this opinion about Thomas-and others like it-did not begin with his Grutter dissent.

131. Thomas knows he is being viewed and does not completely reject this role; he makes a point of speaking to black audiences and schoolchildren. See, e.g., Ron SUSKIND, A HOPE IN THE UNSEEN 115-23 (1998).

132. For an overview of Thomas's opinions in the Court's affirmative action cases through 1997, and the resulting criticisms he received from the civil-rights community and critical race scholars, see generally Scott D. Gerber, Justice Clarence Thomas and the Jurisprudence of Race, 25 S.U. L. REv. 43, 79-93 (1997).

133. Cf. Dowd, supra note 8, at A25 ("It's poignant, really. It makes him crazy that people think he is where he is because of his race, but he is where he is because of his race.").

134. See infra Part 1Il.A.1 for more on the nature of the stigma injury. 
it spawned show that some of those walking through-some of those visible people-may not be walking so tall. If they carry a stigma, does the "visibly open" rationale depend on young minorities looking at racial minorities in positions of power and not inquiring as to how they got therenot figuring out that affirmative action almost certainly helped? ${ }^{135}$

In reality, there is anger at and from Justice Thomas. He is Exhibit A: a black person who has felt stigmatic harm from others questioning his competency and pressuring him to conform to racial stereotypes. ${ }^{136} \mathrm{He}$ is also a Justice of the Supreme Court who made a constitutional argument in Grutter that such harm to purported beneficiaries can affect the calculus that determines whether affirmative action can be supported by a compelling interest. His critics are wrong to dismiss Thomas for being angry. Rather, they should recognize that his anger is now situated in the law and offers something to the legal discourse.

\section{Is "Diversity" Now Stronger or Weaker in the New Calculus?}

The conventional wisdom is that diversity in the new calculus is better supported than it was in Bakke because a majority of the Justices endorsed the compelling interest as expressed by O'Connor. Yet as I showed in Part I, Bakke's diversity rationale has been transformed. Diversity for whites and for educational institutions has been joined in Grutter by rationales for society and for racial minorities. It is unclear, however, whether the additional two rationales make the diversity rationale writ large- the compelling interest as a whole-stronger, or whether it is weaker because there are more avenues of attack now available.

To begin with, it is important to consider whether undermining one rationale, as Thomas's Grutter opinion sought to do, undermines the entire diversity interest - or, alternatively, whether knocking out one rationale (through argument, social science, or some other method) merely leaves the other two diversity rationales to defend affirmative action. In other words, is O'Connor's version of the overall diversity rationale stronger visà-vis Powell's because of the inclusion of more reasons for diversity, or did the majority in Grutter only accept the overall diversity rationale because it included all three reasons, such that knocking out one would jeopardize the

135. Cf. Brief for the United States as Amicus Curiae Supporting Petitioners at 23, Wygant v. Jackson Bd. of Educ., 476 U.S. 267 (1986) (No. 84-1340) ("The most powerful role models are those who have succeeded without a hint of favoritism. For example, Henry Aaron would not be regarded as the all-time home run king, and he would not be a model for youth, if the fences had been moved in whenever he came to the plate."). Interestingly, this phrasing was apparently devised by now-Justice Samuel Alito when he was an attorney in the Office of the Solicitor General. See Jo Becker \& Dale Russakoff, Proving His Mettle in the Reagan Justice Dept., WASH. POST, Jan. 9, 2006, at A01.

136. Cf. Stephen Carter, Reflections of an Affirmative Action Baby 12 (1991) ("We bristle when others raise what might be called the qualification question-'Did you get into school or get hired because of a special program?'--and that prickly sensitivity is the best evidence, if any is needed, of one of the principal costs of racial preferences."). 
majority's holding? It may be too much to say that after Grutter, the diversity rationale has three necessary elements - that diversity must be a compelling interest for white people at universities (and for universities themselves), for society, and for minorities-but Grutter relies on much more than Bakke's diversity for whites. Still, would a future Thomas win leave two remaining interests to attack (and two interests for supporters of affirmative action to defend), or does such a win on one obliterate the entire interest?

This question goes to the nature of the new diversity rationale: whether it is indeed one interest or three. Are the three sub-rationales similar in kind to a cat's lives, such that if one were eliminated there would still be two remaining, and that as long as one remains the rationale as a compelling interest-and by extension, affirmative action in higher education-survives? Or are they like the legs of a tripod, such that if one leg were knocked out the entire structure would fall, crushed by the weight of the Equal Protection Clause? Or, somewhere in between, are they like multiple ropes together supporting someone rappelling down a mountain, such that if one rope were to break the other two would still hold the person, but the weight would sag and each rope would have to strain more, perhaps not lasting as long as if the load were being carried by more ropes? ${ }^{137}$ These metaphors can be reconfigured as simply the question of whether the court balances benefits and harms for each rationale, the entire diversity rationale, or both. (This question is the reason the title of this Comment refers with intentional ambiguity to Grutter's diversity "interest(s).")

It is difficult to fathom how knocking out the diversity rationale for racial minorities or even calling it into serious doubt would not doom the affirmative action project. It seems untenable to maintain affirmative action if it is shown to cause more harm than benefit-or barely more benefit than harm - to its intended beneficiaries. How many supporters of preferential admissions could continue to support such policies if they were found to significantly harm racial minorities? However, it is not evident at the present time how the Court would decide. If the stigma argument ever prevails or even comes close, these questions will have to be answered. ${ }^{138}$

137. Cf. William N. Eskridge, Jr. \& Philip P. Frickey, Statutory Interpretation as Practical Reasoning, 42 STAN. L. REv. 321, 351-52 (1990) (applying the chain versus cable metaphor to statutory interpretation). Eskridge and Frickey observe that "[a] chain is no stronger than its weakest link, because if any of the singly connccted links should break, so too will the chain. In contrast, a cable's strength relies not on that of individual threads, but upon their cumulative strength as they are woven together." $I d$. at 351 . The chain concept is akin to my tripod illustration, while the cable is a combination of the cat and the rappeller.

138. That is, they will have to be answered unless the Court decides to abandon the Grutter calculus. For example, the Court might decide when faced with these difficult questions to avoid them by simply returning to the prior (and narrower) Bakke version of the diversity interest. However, for the reasons discussed in Parts $\mathbf{l}$ and $\mathbf{1 l}$ of this Comment, that would be a significant doctrinal development (to say the least). See also infra note 336. 


\section{E. Coda}

The third rationale-diversity's benefits for racial minorities-is where Justice Thomas aimed his dissent. It is also the one with the greatest untapped potential for research and analysis. Thanks to O'Connor's new formulation of diversity and its various benefits, this third door now exists in affirmative action doctrine, and it is ajar. The danger and the opportunity for both sides is that a great force of argument or social science may blow it wide open.

Part III will examine this possibility, using a thought experiment to peer inside and examine some of the issues in this undertheorized area.

\section{III}

\section{Asserting Stigmatic InJury: A Thought Experiment}

As I showed in Part II, Justice O'Connor's formulation of the Grutter diversity interest(s) has opened the door to a consideration of the harms that affirmative action policies may cause racial minorities. Thomas's opinion is one of the first salvos on a new front ("new" in the now-doctrinallysignificant sense) in the perennial debate over affirmative action. The new calculus has created a welcome doctrinal opening for affirmative action's effects on racial minorities to be considered, and more detailed analyses in this area are called for in order to boIster or respond to Thomas's and others' arguments that are sure to come.

Admittedly, stigmatic injury is not the only potential cost of affirmative action borne by racial minorities. There is preliminary empirical data on other sorts of harms, and more ought to be done to develop (or refute) these critiques. These concerns-for example, those related to graduation and dropout rates, classroom performance, and future career achievements - are inputs to the new calculus as well.

For example, the recent study by Richard Sander in the Stanford Law Review produced data and drew conclusions (though hotly contested) on the supposed "mismatch" between minority students and their schools; Sander argued that this mismatch harms minority students. ${ }^{139}$ Sander's article focused on the cost associated with "the lower actual performance that usually results from preferential admissions." 140 If Sander's data and

139. Richard H. Sander, A Systemic Analysis of Affirmative Action in American Law Schools, 57 STAN. L. REv. 367 (2004).

140. Id. at 370 .

A student who gains special admission to a more elite school on partly nonacademic grounds is likely to struggle more, whether that student is a beneficiary of a racial preference, an athlete, or a "legacy" admit. If the struggling leads to lower grades and less learning, then a variety of bad outcomes may result: higher attrition rates, lower pass rates on the bar, problems in the job market. The question is how large these effects are, and whether their Id consequences outweigh the benefits of greater prestige. 
conclusions hold up under the withering scrutiny they have received and no doubt will continue to receive, ${ }^{141}$ this information would have a prominent role to play in the new calculus. ${ }^{142}$

This Comment, however, focuses specifically on stigmatic harm-that is, on what it means for Grutter to represent stigma's opening in the affirmative action legal calculus. Stigma seems to be the most injurious harm from affirmative action, at least according to Justice Thomas; at any rate, his discussion of stigmatic injury is rhetorically the most powerful part of his opinion. Moreover, stigmatic harm is the flip side of the most important phrase in O'Connor's opinion: "visibly open." Thomas's opinion invokes the deleterious marker of stigma and then asks, "Is this what the Court means by 'visibly open'?"143

With the hope of modeling both a potential way forward for litigants and courts and how the new calculus can shape the work of scholars and policymakers, this Part presents a thought experiment that turns the traditional affirmative action litigation narrative on its head. The traditional narrative, exemplified by Bakke, Grutter, and Gratz, consists of white people-rejected applicants-challenging affirmative action policies because of the alleged unfairness to them from having to compete for places in a university or professional school under such policies. This narrative is surely not defunct, but in terms of present litigation and scholarship, it seems nearly exhausted. ${ }^{144}$ Very few facts not specific to the instant case's affirmative action policy are truly in dispute, and the pro and con arguments within this paradigm, though powcrful, have become rather stalc with time and repetition.

The new narrative has a new plaintiff: the stigmatized racial minority. Imagine that instead of someone who looks like Allan Bakke, Barbara Grutter, or Jennifer Gratz, the plaintiff in this new kind of affirmative

141. See, e.g., lan Ayres \& Richard Brooks, Does Affirmative Action Reduce the Number of Black Lawyers?, 57 StAN. L. REv. 1807 (2005); David L. Chambers et al., The Real Impact of Eliminating Affirmative Action in American Law Schools: An Empirical Critique of Richard Sander's Study, 57 Stan. L. Rev. 1855 (2005); Michele Landis Dauber, The Big Muddy, 57 Stan. L. Rev. 1899 (2005); David B. Wilkins, A Systematic Response to Systemic Disadvantage, 57 STAN. L. REv. 1915 (2005); see also Daniel E. Ho, Scholarship Comment, Why Affirmative Action Does Not Cause Black Students To Fail the Bar, 114 YALE L.J. 1997 (2005). For Sander's responses, sce Richard H. Sander, A Reply to Critics, 57 Stan. L. Rev. 1963 (2005); Richard H. Sander, Mismeasuring the Mismatch: A Response to Ho, 114 YALe L.J. 2005 (2005).

142. Sander says he gives "short shrift" in his article to stigmatic harm, though "[t]hese effects are interesting and important." Sander, supra note 139, at 369; see also infra text at note 205 . However, like Thomas, Sander's focus "is on the effects racial preferences in admissions have on the largest class of intended beneficiaries: black applicants to law school." Sander, supra note 139, at 369. (Sander has said he plans to focus on other bencficiaries of color in subsequent scholarship.) And, conducive to the new calculus, Sandcr's "principal question of interest is whether affirmative action in law schools generates benefits to blacks that substantially exceed the costs to blacks." Id.

143. See Grutter v. Bollinger, 539 U.S. 306, 373 (2003) (Thomas, J., concurring in part and dissenting in part); see also supra Part 11.C.4.

144. See also infra Conclusion. 
action challenge is a person of color and that the chief complaint this person alleges is a denial of equal protection based on the stigmatic harms caused by an affirmative action policy operating at a state university to which he or she is applying. ${ }^{145}$ This Part raises issues such a challenge would pose and suggests strategies courts may use when faced with this kind of case. ${ }^{146}$

A challenge to affirmative action policies after Grutter requires that those opposed to affirmative action think outside the box. In his Grutter dissent, Justice Scalia essentially described a future litigation strategy for opponents of affirmative action after the "split double header" of Grutter and Gratz. ${ }^{147} \mathrm{He}$ seemed to be acting almost as a consultant, trying to set forth a roadmap for conservative litigation organizations. But of the six kinds of suits Scalia envisioned arising, ${ }^{148}$ a challenge to affirmative action on stigmatic grounds by a racial minority was not one.

Yet this kind of challenge has been hinted at before. Specifically, Justice Stevens, in a footnote in his dissent in Adarand, questioned Justice Thomas's consideration of stigma in that case by reminding the Court that "[n]o beneficiaries of the specific program under attack today have challenged its constitutionality - perhaps because they do not find the preferences stigmatizing, or perhaps because their ability to opt out of the program provides them all the relief they would need." 149 Scholars have also raised concerns about white plaintiffs raising the stigma argument, ${ }^{150}$ with the implication that a black plaintiff, for example, might satisfy that concern. This thought experiment raises this kind of challenge from the

145. For a more specific breakdown of the kinds of plaintiffs in this challenge and the injuries they can assert, see infra Part III.A.1.

146. The purpose requirement of Washington v. Davis, 426 U.S. 229 (1976), which might seem fatal for this kind of case, actually should not apply to this kind of challenge. That case's requirement that a plaintiff show the state acted with a discriminatory purpose in order for its equal protection claim to succeed applies to plaintiffs challenging facially neutral state actions-unlike an affirmative action policy, which explicitly classifies on the basis of race. As the Court stated in Shaw v. Reno, "No inquiry into legislative purpose is necessary when the racial classification appears on the facc of the statute." 509 U.S. 630,642 (1993). Instead of requiring a showing of purpose, the Court uses strict scrutiny to smoke out invidiousness. See also Johnson v. California, 125 S.Ct. 1141, 1148 (2005) (emphasizing that "[blccause the ... policy is an express racial classification, it is "immediately suspect," and that therefore strict scrutiny applies) (citing Shaw, 509 U.S. at 642; Washington v. Seattle Sch. Dist. No. 1, 458 U.S. 457, 485 (1982)). For a critique of the Court's use of the term "express classification" in Johnson, including its citation to Washington v. Seattle School District No. l, see Vikram David Amar, The Supreme Court Expresses Skepticism About a California Policy That Temporarily Segregates Prisoners By Race, FIndLAw's WRIT, Mar. 4, 2005, http://writ.news.findlaw.com/amar/ 20050304.html.

147. See Grutter, 539 U.S. at 348 (Scalia, J., concurring in part and dissenting in part).

148. See id. at 348-49.

149. Adarand Constructors, Inc. v. Pena, 515 U.S. 200, 247-48 n.5 (1995) (Stevens, J., disscnting); see also infra Part I11.A.

150. See also infra Part III.A. 
kind of plaintiff Stevens had in mind. ${ }^{151}$ But unlike those who bring up the issue of the plaintiffs' race as a conversation-ender when concerns about stigma are raised or only hint in asides at the potential for minority plaintiffs to assert stigmatic harm, this Part addresses this possibility directly.

\section{A. Standing to Raise a Stigma Challenge to Affirmative Action}

Any federal suit must first satisfy a standing inquiry, and this hypothetical one is no exception. This Section examines standing not only because it is a necessary threshold ${ }^{152}$ but also because an analysis of standing will help clarify some of the issues my hypothetical lawsuit raises.

Standing is an important issue in this hypothetical in part because judges and scholars have raised questions (correctly, in my view) about the consideration of stigmatic harm when the litigants are those like Allan Bakke, Barbara Grutter, and Jennifer Gratz. ${ }^{153}$ Indeed, some of the purposes of standing doctrine seem to preclude white plaintiffs from making a claim based on stigmatic harm to racial minorities. Standing requires the plaintiff to allege "such a personal stake in the outcome of the controversy as to assure that concrete adverseness which sharpens the presentation of issues upon which the court so largely depends for illumination of difficult constitutional questions." 154 Although white plaintiffs under the traditional affirmative action paradigm have been and certainly would be concerned with the overall outcome of a case, if a case depends in large part on an examination of the stigmatic harm to racial minorities, one might be skeptical about how illuminating a presentation from white plaintiffs would be in this respect. Also, "courts should not adjudicate ... rights unnecessarily, and it may be that in fact the holders of those rights either do not wish to assert them, or will be able to enjoy them regardless of whether the in-court litigant is successful or not." 155 It is possible racial minorities do not wish

151. He goes on to write that even if such a challenge were lodged, he would not find Thomas's arguments persuasive, in part due to his reading of Washington $v$. Davis (though Stevens is sympathetic to the "common sense" appeal of focusing on effects instead of intent) and in part out of deference to legislative judgment. See Adarand, 515 U.S. at 248 n.5 (Stevens, J., dissenting).

152. The three elements of Parts 11I.A.1-3 are the "irreducible constitutional minimum" for standing. Lujan v. Defenders of Wildlife, 504 U.S. 555, 560 (1992).

153. See, e.g., David S. Schwartz, The Case of the Vanishing Protected Class: Reflections on Reverse Discrimination, Affirmative Action, and Racial Balancing, 2000 WIs. L. REv. 657, 669 ("As a legal matter, it is difficult to see how the stigma purportedly laid on minorities by affirmative action gives standing to whites to sue for reverse discrimination.").

154. Baker v. Carr, 369 U.S. 186, 204 (1962).

155. Singleton v. Wulff, 428 U.S. 106, 113-14 (1976) (Blackmun, J., plurality opinion); see also Richard Delgado, 1998 Hugo L. Black Lecture: Ten Arguments Against Affirmative Action-How Valid?, 50 AlA. L. REv. 135, 138-39 (1998) ("A paternalistic argument, [the stigma argument] holds that we should reject affirmative action, even though most people of color support it, because it would only injure them. If they knew their own self-interest, they would oppose it. This argument tends to be made by liberals who genuinely like minorities but worry about their blaek friend with the 1Q of 149 , who may be unfairly labeled an affirmative-action baby."); Patricia Williams, The Obliging Shell: $A n$ 
to bring suit asserting stigmatic harm, do not believe they have been stigmatized, or do not believe the stigma would be reduced or eliminated even if they prevail and affirmative action programs are eliminated. ${ }^{156}$ Out of respect for the injured's wishes and courts' limited resources, requiring plaintiffs to assert their own harms has its benefits.

Relatedly, courts require plaintiffs to plead their own injuries in part to guard against purely ideological motives and stakes ${ }^{157}$ - a very real risk in the affirmative action context. Indeed, some commentators' caution about white plaintiffs' standing in a stigma case arises out of a strong suspicion that white plaintiffs making such a claim are being disingenuous. ${ }^{158}$ Richard Delgado acknowledges that the stigina argument can be "made by some principled conservatives who actually fear affirmative action will do more harm than good and do not want that harm to befall blacks."159 However, he notes, "it is also made disingenuously by people who do not much like blacks or Mexicans at all, much less care if they are stigmatized, but think it is a good argument against something they dislike and want to see ended." 160 Although there is no way to test litigants' motivations formally, standing doctrine should make it much less likely for the latter group to be able to go into court and assert stigmatic harm.

It seems possible that the stigma argument cannot get traction with traditional affirmative action plaintiffs. Allan Bakke, Barbara Grutter, and Jennifer Gratz were all white plaintiffs. If there is a harm, the remedy ought to fit the plaintiffs. Under prudential third-party standing limitations, even if plaintiffs satisfy Article III standing requirements, they ought to raise their own interests and not those of others. ${ }^{161}$ The reasons are sound.

Informal Essay on Formal Equal Opportunity, 87 MicH. L. REv. 2128, 2141 (1989) ("It is demeaning to be told what we find demeaning.").

156. See also infra Part III.A.3.

157. See, e.g., United States v. Richardson, 418 U.S. 166, 192 (1974) (Powell, J., concurring) (noting "the traditional hostility of the Court to federal taxpayer or citizen standing where the plaintiff has nothing at stake other than his interest as a taxpayer or citizen. It merits noting how often and how unequivocally the Court has expressed its antipathy to efforts to convert the Judiciary into an open forum for the resolution of political or ideological disputes about the performance of government.").

158. See, e.g, Schwartz, supra note I53, at 669 ("But is thc 'stigma' they describe worse than the stigma of exclusion from opportunities? The fact that affirmative action is strongly supported by racial and ethnic minorities suggests that for most people, the stigma of exclusion is worse; and in any event, it would be particularly 'patronizing' for policymaking judges to reject affirmative action to protect racial minorities from their own (hypothesized) feelings of stigma. 1 suspect that most whites who attach a stigma to affirmative action are simply seizing on affirmative action as a convenient handle for attitudes of racial superiority they harbor anyway."); see also Liu, supra notc 7, at 1100 ("It would thus be ironic-and not a little disingenuous - for a white plaintiff challenging affirmative action to prevail on the ground that racial preferences hurt minority students.").

159. Delgado, supra note 155 , at $138-39$.

160. Id.

161. See Warth v. Seldin, 422 U.S. 490,499 (1975) (“" $E]$ ven when the plaintiff has alleged injury sufficient to meet the 'case or controversy' requirement, this Court has held that the plaintiff generally must assert his own legal rights and interests, and cannot rest his claim to relief on the legal rights or interests of third parties."). 
Since courts exist to settle real disputes raised by real plaintiffs, if plaintiffs do not want to invoke their own rights and claim a violation of them, then that wish should be respected and others should not be able to raise such a challenge. ${ }^{162}$ And, plaintiffs are best able to articulate the richness of their own claims. ${ }^{163}$ Plaintiffs get to frame the case, and white plaintiffs are unlikely to assert stigmatic concerns in the same manner as minority plaintiffs.

There is an exception to third-party standing doctrine for plaintiffs who assert claims for others who are not able to bring challenges themselves, ${ }^{164}$ but that exception does not seem to apply here, as no "practical obstacle" exists for a minority who believes he is injured by an affirmative action policy to bring suit asserting his own rights. ${ }^{165}$ There is no indication a minority plaintiff is unable to access the courts or that there is some "practical obstacle" impeding such access. Although a black plaintiff challenging affirmative action in court might be shunned or ostracized by many in his community for bringing suit, this risk would likely not grant another the standing to sue on his behalf. Third-party standing is not only inapplicable in a case like this, but claiming it is necessary would also be somewhat offensive in its paternalism.

Before beginning the examination of Articlc III standing in the context of my thought experiment, it must be acknowledged that standing doctrine is not known for its clarity (to put it mildly). ${ }^{166}$ Making predictions about standing is a lot like making predictions about the weather: there are classifications and some modicum of predictability, but it is a very inexact science. That said, the three constitutional requirements for standing provide a useful register for clarifying the nature of this hypothetical challenge to an affirmative action policy based on stigmatic harm to racial minorities. The following discussion considers doctrine, but more importantly, it uses standing as a launching pad for considering some issues raised by bringing this challenge.

162. See Duke Power Co. v. Carolina Envtl. Study Group, Inc., 438 U.S. 59, 80 (1978) (finding that limitations on standing serve to avoid "the adjudication of rights which those not before the Court may not wish to assert").

163. See Singleton v. Wulff, 428 U.S. 106, 114 (1976) (Blackmun, J., plurality opinion) (“‘T]hird parties themselves usually will be the best proponents of their own rights.").

164. See Sec'y of State v. Joseph H. Munson Co., 467 U.S. 947, 956 (1984) ("Where practical obstacles prevent a party from asserting rights on behalf of itself, for example, the Court has recognized the doctrine of jus tertii standing.").

165. See id.; Warth, 422 U.S. at 510 ("Nor do the ... petitioners show that their prosecution of the suit is necessary to insure protection of the rights asserted, as there is no indication that persons who, in fact, [may have had their rights violated] are disabled from asserting their own right in a proper case.").

166. Cf. Flast v. Cohen, 392 U.S. 83, 129 (1968) (Harlan, J., dissenting) (calling standing law "a word game played by secret rules"). 


\section{Injury: What is the Stigmatic Harm?}

For plaintiffs to have standing, they must first show that they have "sustained or [are] immediately in danger of sustaining some direct injury," and that this "injury or threat of injury must be both real and immediate, not conjectural or hypothetical." 167 This injury must be "conerete and particularized" and "actual or imminent."168 This Section first considers these doetrinal requirements by examining four different hypothetical plaintiffs, all racial minorities. These plaintiffs may be in the minority among racial minorities, ${ }^{169}$ but their claims deserve attention.

\section{a. Adams}

The first plaintiff, whom I shall call Adams, is perhaps the most susceptible to feeling stigmatic harm. Adams challenges an affirmative action policy operating at a state university to which he is in the process of applying. ${ }^{170}$ Adams is a minority applicant who charges that the application procedure that he is about to enter into or is actually entering into ${ }^{171}$ subjects him to the very real threat of "imminent" injury: applying with the

167. City of Los Angeles v. Lyons, 461 U.S. 95, 101-02 (1983) (intemal quotation marks omitted).

168. Lujan v. Defenders of Wildlife, 504 U.S. 555, 560 (1992).

169. See also infra Part III.B.3.

170. Adams likely must be entering into, or "imminent[ly]" about to enter into (see Lujan, 504 U.S. at 560), the application process in order to satisfy the requirement that his injury not be too "conjectural or hypothetical." See Lyons, 461 U.S. at 102; see also infra note 171. This issue may seem like it could easily be avoided: simply have the plaintiff be a minority student already at the university - that is, have this plaintiff be someone who applied, was admitted, and has enrolled. Alas, it is not that simple. Though this other plaintiff's assertion of injury may be inore forceful (for example, his testimony of the actual stigmatization he has already suffered at the university would surely be more personal and detailed), such a plaintiff may not be able to satisfy the requirement from Lyons that, when seeking injunctive relief (in this case, an end to the affirmative action policy), a plaintiff must show a "sufficient likelihood that he will again be wronged in a similar way" by this policy. Lyons, 461 U.S. at 111 . This bar is one that a student who applied, was admitted, and (most significantly) has already enrolled likely cannot clear. Additionally, this enrolled plaintiff may not be able to satisfy the redressability requirement for standing, discussed infra Part III.A.3, because a favorable decision resulting in an injunction against the affirmative action policy likely would not redress his stigmatic injury because clearly he was already enrolled and (most importantly) had already been admitted under the now-old affirmative action admissions policy. However, this Comment does not seek to make a definitive argument that such a plaintiff cannot bring suit; indeed, the Lyons requirement of likely future injury does not apply to suits that do not seek injunctive relief, though there may be other legal obstacles (as well as strategic drawbacks) present in such a case.

171. Adams need not have "actually applied" to the university in order to assert his injury. In order to have standing to seek prospective relief, he need only demonstrate that he is "'able and ready' to apply" should the university's policy change. See Gratz v. Bollinger, 539 U.S. 244, 262 (2003) (quoting Ne. Fla. Chapter of the Associated Gen. Contractors of Am. v. City of Jacksonville, 508 U.S. 656, 666 (1993)). Although this precedent arose in the old paradigin of affirmative action litigation, there is no apparent reason why it should not apply here to this hypothetical new kind of case. (However, it must be noted that in Gratz, it is possible that plaintiff Hamacher was aided in his ability to demonstrate to the Court his " ab[ility] and read[iness]' to apply" as a transfer student by the fact that he had already applied (and was denied admission) as a freshman applicant. See id. It is unclear what weight, if any, the Court gave this fact in determining that Hamacher had the requisite intent to give him standing to seek prospective relief.) 
existence of an admissions process that will not treat him equally because of his race, and the stigmatization from being admitted under such a policy that he argues will surely occur-and be suffered by him-if he enrolls. Adams, likely a high school senior (or, alternatively, someone about to apply to law school or medical school), wants to avoid the inevitable stigmatization that, assuming he enrolls, will have accrued as soon as he started an application process that did not treat him equally because of its policy of making admission relatively easier for members of his race.

Adams represents all racial minorities who, if admitted to the university under the existence of the affirmative action policy, would feel stigmatized-those people of color who would be in the "After" portrait discussed earlier. ${ }^{172}$ Adams contests the burden of having to continually prove himself to thers because of the stigma of being admitted under the affirmative action policy and the different standards it uses. Adams is aware his race would play a large role in getting him admitted, others would be aware of this, and Adams knows (or at least strongly suspects) that others would know.

Not only does Adams contest the burden based on what the stigma will signal to others, but he resents it and doubts himself. Shelby Steele, a prominent black conservative writer, has written how " $[\mathrm{t}]$ he effect of preferential treatment-the lowering of normal standards to increase black representation - puts blacks at war with an expanded realm of debilitating doubt." 173 Because of both the stigma signaled to others and the self-doubt Adams may feel, affirmative action's stigmatic harm undermines his confidence. He may ask himself, "Would I have been admitted if I were not a racial minority? How comparatively qualified am I really?"174 Adams's injury, due to affirmative action's effects on him and on others' perceptions of him (which in turn affects Adams), would be in large part psychological.

A prominent writer on stigma, Erving Goffman, has written about the experience of stigma of the "discredited."175 For the discredited, "the stigmatized individual assume[s] his differentness is known about already

172. However, some of those in the "After" portrait--in particular, those few who would also be in the "Before" portrait-will be dealt with specifically in the discussion of hypothetical plaintiff Baker, at infra Part IlI.A.1.b.

173. Shelby Steele, The Content of Our Character: A New Vision of Race in America 117 (1990). Steele continues the sentence by stating that "the doubt itself becomes an unrecognized preoccupation that undermines their ability to perform, especially in integrated situations." Id. at 117 18. The alleged undermined ability to perform is not itself the stigma, though it is an outgrowth from the stigma.

174. Professor Linda Hamilton Krieger describes a version of this argument as such: "To the extent that non-merit criteria are used, selected members of preferred groups will be unsure about the reasons for their success. This uncertainty creates a sense of self-doubt and self-derogation in affirmative action beneficiaries." Linda Hamilton Krieger, Civil Rights Perestroika: Intergroup Relations After Affirmative Action, 86 CALIF. L. REv. 1251, 1259 (1998). Krieger cites Steele as "[t]he classic statement of this argument." Id. at 1259 n.13.

175. Erving Goffman, Stigma: Notes on the Management of Sponled 1dentity 4 (1963). 
or is evident on the spot."176 The differentness from the normal in the case of university admissions may be due to the fact that the "normal" admissions qualification is merit. Some have argued that the meritocracy based on prior tests and grades needs to give way to a new paradigm. ${ }^{177}$ That may be the case, but as long as the standard is merit and those not treated in the normal way are different not only in their treatment but also in that they are disproportionately racial minorities and are treated differently because of their race, the stigma attaches. Because of this and its effect on to his beliefs in himself and about the beliefs of others, Adams would not know "what the others present are 'really' thinking about him."178 Moreover, "during mixed contacts, the stigmatized individual is likely to feel that he is 'on,' having to be self-conscious and calculating about the impression he is making, to a degree and in areas of conduct which he assumes others are not."179 This is similar to the harms articulated above. The very real and concrete injuries here that Adams asserts he himself will feel imminentlythe burdens and the accompanying self-doubt-constitute the "injury" aspect of standing for his suit challenging the affirmative action policy.

\section{b. Baker}

Baker, another minority student, is an academic star at her high school. She excelled in classes and on standardized tests, and by the time the college application season rolled around, many universities, made aware of her top test scores by the College Board, had already sent her copies of their viewbooks and applications. ${ }^{180}$ For the purposes of this thought experiment, we know that even without an affirmative action policy in place, she would almost certainly be admitted to the selective university to which she is now applying. Easily admitted, Baker would be in the "After" portrait, but she is one of the few faces of color-unfortunately, it is still only a few-who would also be in the "Before" portrait.

Baker would be admitted anyway, yet her qualifications will still be called into question. She may not feel the debilitating self-doubt that Adams may feel, but she will be a person of color admitted by a school with an affirmative action policy and so may nevertheless carry what Steele calls "the stigma of questionable competence." notes, the "implication of inferiority in racial preferences" can lead to "an

176. Id. For a discussion of the importance of visibility to this kind of stigma, see infra Part III.A. 2 .

177. See, e.g., Lani Guinier, The Supreme Court, 2002 Term-Comment: Admissions Rituals as Political Acts: Guardians at the Gates of Our Democratic Ideals, 117 HARV. L. Rev. 113 (2003).

178. GofFMaN, supra note 175 , at 14 .

179. Id.

180. 1 use the high school example for Baker, but, just as for Adams, the facts can be slightly altered so that Baker is instead the excellent college student or graduate now in the process of applying to law school or medical school.

181. STEele, supra note 173 , at 120. 
enlargement of self-doubt." 182 Even though Baker could also gain admission without affirmative action, it would not be unreasonable for Bakerher sterling qualifications and abilities nevertheless unfairly doubted by others because of the affirmative action policy-to develop some doubts about herself and her place at the university. Yet even without feeling any such doubts, she has been "tarred as undescrving" by the existence of the affirmative action policy that exists as part of the admissions regime under which she is applying and will be admitted, when in fact she would be just as deserving (again, if the standard is mainly "merit" and one's prior academic success), if not more so, as a white peer who would live just down the hall in her dormitory.

Baker is injured by the university's policy of giving racial preferences because she is someone who does not need affirmative action to be admitted. Baker does not like that, as a result of this policy, her qualifications will be called into question by others-now and in the future. Justice Thomas, though writing in this instance about "blacks tak[ing] positions in the highest places of government, industry, or academia," could very well also be writing about Baker in her search for her first job. For such leaders as for Baker, "it is an open question today whether their skin color played a part in their advancement. The question itself is the stigma-because either racial discrimination did play a role, in which case the person may be deemed 'otherwise unqualified,' or"-as in Baker's case- "it did not, in which case asking the question itself unfairly marks those blacks who would succeed without discrimination."183 Stigma's relation, negative stereotyping, will harm Baker: her success will be wrongly attributed to racial preferences. Assumed to have been admitted more easily, she therefore can be viewed just as Adams is. Though her injuries are not necessarily the same, Baker is also injured by the university's unequal treatment of applicants on the basis of race, and she brings suit. ${ }^{184}$

\section{c. Clark}

Unlike Adams and Baker, the other two hypothetical plaintiffs will have a more difficult time asserting an injury that a court may recognize. One of these plaintiffs is Clark. Clark, a forty-year-old black executive who graduated in his early twenties from a selective university that practiced affirmative action in its admissions policies, just came to the

182. Id. at $116-17$.

183. Grutter v. Bollinger, 539 U.S. 306, 373 (2003) (Thomas, J., concurring in part and dissenting in part).

184. Some commentators are most sympathetic to this kind of person challenging an affirmative action policy. See, e.g., Liu, supra note 7, at 1100 ("[S]uch stereotyping concerns are not ones that white plaintiffs have any standing to raise. Indeed, the person best positioned to raise these issues is a minority student who would have been admitted, or was in fact admitted, without any benefit from affirmative action."). 
realization that he was tired of being labeled an "affirmative action student" from his alma mater whenever he sent out résumés to firms in search of a better position for himself. Moreover, assuming he was an applicant to the university who was helped at the time by the existence of the policy (more like Adams than Baker), Clark is also sick of the self-doubt that has festered and grown. Clark, therefore, decides to bring suit against his university to challenge its affirmative action policy. ${ }^{185}$

Clark is certainly not alone in his frustrations and doubts. Stephen Carter has described the situation for those "trapped by the best black syndrome": "We cannot afford, ever, to let our standards slip. There are too many doubters waiting in the wings to pop out at the worst possible moment and cry, 'See? Told you!"' 186 And it is not only others' doubting, but self-doubt as well. As William Bowen and Derek Bok have observed, "high-achieving black graduates continue to seek reassurance that they have 'made it on their own," noting how "they complain when job interviewers presume that even the most outstanding black student may well have been helped in this way." ${ }^{187}$ Even without any self-doubt, Justice Thomas described in Grutter how "[w]hen blacks take positions in the highest places of government, industry, or academia, it is an open question today whether their skin color played a part in their advancement." 188

Clark, no matter what he did after college, may, by the nature of the admissions process, always be stigmatized as having been admitted under lower standards. Yet although the injury is quite "real," courts may question whether it is too attenuated and not "immediate" enough. ${ }^{189}$ There may also be causation and redressability issues, such as whether the stigma actually comes from his employcrs' affirmative action policies. And the further in time Clark is removed from the affirmative action decision he is questioning, the more likely it is that other aspects of Clark come into consideration aside from that initial admission decision. Although courts are far from predictable on the injury prong of standing, one may very well doubt whether Clark is still able to assert a cognizable claim of injury from his university's affirmative action policy. ${ }^{190}$

185. Let us assume Clark was admitted to his university in the early 1980 s-thus after Bakkeand that, although his university has altered its admissions policy slightly since then, the basic features remain the same as when Clark was admitted.

186. CARTER, supra note 136 , at 58.

187. BOWEN \& BoK, supra note 69, at 265.

188. Grutter, 539 U.S. at 373 (Thomas, J., concurring in part and dissenting in part).

189. Cf. City of Los Angeles v. Lyons, 461 U.S. 95, 101-02 (1983).

190. Courts also may question whether, this many years later, Clark really is injured, or if he is just articulating an ideology. $C f$. infra Part HII.A.1.d. 


\section{d. Dixon}

The final hypothetical plaintiff, Dixon, is the least likely to clear the standing hurdle successfully. Dixon is a person of color opposed to affirmative action in university admissions because of what the existence of such a policy says about people of her race. What it expresses makes Dixon feel less good about herself, and she believes it causes others to think poorly of people of her race-including, of course, her-as well as other racial minorities.

Unlike Adams's, Baker's, and even Clark's more particularized challengcs, Dixon's challenge is more abstract. In Allen v. Wright, plaintiffs were parents of black public school children who brought a nationwide class action challenging the Internal Revenue Service's policy allowing tax excmptions for privatc schools that discriminated on the basis of race. ${ }^{191}$ The Court in Allen held that plaintiffs' alleged stigmatic injury was not cnough to satisfy the injury requirement of Article III standing. The Court chose not to recognize "abstract stigmatic injury" out of a concern that, for example, "[a] black person in Hawaii could challenge the grant of a tax exemption to a racially discriminatory school in Maine."192 "[S]tigmatizing injury ... caused by racial discrimination," the Court stated, "accords a basis for standing only to "those persons who are personally denied equal treatment' by the challenged discriminatory conduct." 193 Whatever one thinks of Allen, the claims by hypothetical plaintiffs Adams, Baker, and Clark likely clear this particular bar, while Dixon's challenge, based mostly on expressive concerns, likely fails because of it. ${ }^{194}$

191. Allen v. Wright, 468 U.S. 737, 739 (1984).

192. Id. at 755-56; see also Note, Expressive Harms and Standing, 112 HARv. L. REv. 1313, 1330 (1999) (noting that this concern "seems to be a reflection of the fear that, without a limiting principle, purely ideological plaintiffs who are themselves unaffected by the racial stigma would attempt to bring suit. The Court could have used physical proximity to ensure the concreteness of the injury, however, without requiring that the plaintiffs actually apply to and be excluded from the racially discriminatory schools."). The Court was not only concerned with ideologically motivated plaintiffs, but was also driven by a separation-of-powers concern. See Allen, 468 U.S. at 761 (describing the case as "brought ... not to enforce specific legal obligations whose violation works a direct harm, but to seek a restructuring of the apparatus established by the Executive Branch to fulfill its legal duties."). Whether this consideration of the merits of the case in the Court's standing inquiry is proper is open to debate.

193. Allen, 468 U.S. at 755 (internal citation omitted).

194. The language of "stigma" can be employed in multiple ways. Recently, there has been some discussion of stigmas involving the expressive content of laws-what laws communicate. See, for example, the debate between Matthew D. Adler, Expressive Theories of Law: A Skeptical Overview, 148 U. PA. L. Rev. 1363 (2000) and Elizabeth S. Anderson \& Richard H. Pildes, Expressive Theories of Law: A General Restatement, 148 U. PA. L. REv. 1503 (2000). Anderson and Pildes call stigmatic harm "an independent expressive harm" and contrast "the causal consequences of laws violating equal protection - that is, their tendency to damage their targets' self-esteem"-with their use of "stigma," which is concerned with "the fact that stigmatizing laws communicate a message of inferiority." Anderson \& Pildes, supra, at 1542. They argue that the Court sees it their way, and that that is as it should be. See id. at $1542-45$.

This Comment is not concerned with the law's expressive harm per se-what the law says about the worth of minorities by taking race into aceount. Rather, the concern here is what the law does-the 


\section{e. "But Can You Prove It?": The Role of Social Science}

Stigmatic harm has been examined by social scientists in a number of different studies. These studies conflict-as do their methodologies. Some claim to prove stigma, while others dispute its existence. ${ }^{195}$ Professor Linda Hamilton Krieger reviewed the evidence on stigma in 1998 and found that "empirical investigations of the self-derogating effects of affirmative action so passionately described in the popular literature paint no clear picture and suggest no clear policy direction."196

However, Krieger separately examined the literature on whether preferences reinforce stereotypes. She described the gcneral argument as follows: "nonbeneficiaries who suspect that preferences played a part in decision making will assume that merit-based criteria alone would not have selected preferred group members. Because preference permits people to attribute preferred group members' success to factors other than merit, affirmative action reinforces stereotypic assumptions of outgroup inferiority and thus hampers stereotype change." 197 Her characterization of the evidence on stereotyping was more definite: "the weight of empirical evidence reasonably supports the view that using preferences tends to exacerbate subtle forms of intergroup bias in the evaluation of affirmative action beneficiaries."198

Yet in many ways, stigma is bound up with stereotype-and vice versa. As Goffman notes, "[a] stigma... is really a special kind of

university's policy of affirmative action that stigmatizcs racial minorities, and that all racial minorities are stigmatized because of this policy. (That is why the causation and redressability inquiries infra are important-not only for standing doctrine but also as a register for fleshing out this harm.) Importantly, this is in line with Thomas's concern with stigma. He wrote in Grutter about "the open question" brought about by an affirmative action policy, and that "the question itself" is the stigma. See supra Parts 11.C.1 and 11.C.4. Even in his Adarand concurrence, whcre he wrote (as part of his "moral" argument, see supra Part II.C.3) about how affirmative action "programs stamp minorities with a badge of inferiority," Thomas was referring to the "programs" and how they, inter alia, "engender attitudes" and "cause [minoritics to] develop dependencies." See supra text at note 126. Though Thomas would likely agree that racial classifications are harmful in and of thcmselves, his concern here is more than just stigma as an "expressive harm" based on what the law's classification itself communicates. His concern-and ours-is the harm felt by racial minorities from affirmative action policies. (See generally supra Parts I and II for why this is now our concern.)

195. For a catalog of evidence supporting and opposing the notion that stigmatic harm exists, see Halaby \& McAllister, supra note 106, at 237 n.7. Reviewing these sourccs, the authors conclude, "The empirical studies and surveys, which... are vast in number, ultimately appear to be hopelessly conflicted on the question of stigma as an empirical mattcr." Id.

196. Krieger, supra note 174, at 1263 ("Research findings so complex and contradictory provide a poor foundation for public policy making, and from the standpoint of advocates on either side of the debate, can probably best be described as unhelpful."). But see infra tcxt at note 207 (noting that Krieger points out that most of these studies examined affirmative action for women, not racial minorities).

197. Id.

198. Id. Moreover, "[r]esearch findings on this question are somewhat more straightforward and provide a more substantial basis for concern than those rclating to affirmative action's potential selfderogating effects." Id. For an explication of the cvidence on stereotyping, see id. at 1263-70. 
relationship between attribute and stereotype." ${ }^{\prime 199}$ Minority students' success at achieving admission appears due to some reason besides merit, and with most others being admitted under different, nonracial standards - that is, admitted under higher academic standards-all minority students may be viewed as inferior and any success may be discounted. The stigmatic harm for Baker, for example, is that someone who did not even need affirmative action is marked by it because she nevertheless faces skepticism as to her qualifications. That negative stereotyping is related to stigmatization does not minimize the varied social science evidence on stigma, but it does suggest that this evidence's apparent lack of clarity is somewhat mitigated by the "somewhat more straightforward"200 findings from studies on stereotyping.

Even if stigmatic harm cannot be measured, it may very well exist. ${ }^{201}$ Indeed, commentators on both sides of the racial preferences debate usually recognize it. ${ }^{202}$ Bowen and Bok, who have made the most significant empirical contribution to the affirmative action literature thus far, have recognized stigma as a cost borne by, for example, "more than a few black students. ${ }^{203}$ Moreover, proponents may agree that stigma is a real cost of affirmative action but simply do not consider it formally because they believe or assume the benefits outweigh the harm..$^{204}$ Even Richard Sander, whose recent controversial study examined the costs to blacks from affirmative action and found them to be substantial, focused on the "mismatch" problem instead of "rather subtle matters, such as the stigma and stereotypes that might result from differential admissions standards," because, although " $[\mathrm{t}]$ hese effects are interesting and important, ... I give them short shrift for the most part because they are hard to measure and there is not enough data available that is thorough or objective enough for my purposes."205

Yet Justice Thomas's statement in Grutter that "[b]eyond the harm the Law School's racial discrimination visits upon its test subjects, no so-

199. GofFMAN, supra note 175 , at 4 .

200. See supra note 198.

201. Cf. SCHUCK, supra note 40, at $180-81$ ("A cost of preferences that is impossible to measure is the insidious innuendo about the deserts of almost all but the most unquestionably superior performers in the preferred group-and perhaps even of them. Ironically, this innuendo tends to perpetuate the very stereotypes that affirmative action was supposed to dispel. That these costs are often invisible and unacknowledged does not make them any less real and cruel ....").

202. See, e.g., id.; infra note 203.

203. BowEN \& BoK, supra note 69 , at 264-65 ("[R/ace-sensitive admissions policies result in costs as well as benefits for at least somc of the intended beneficiaries. The very existence of a process that gives explicit consideration to race can raise questions about the true abilities of even the most talented minority students ('stigmatize' them, some would say). ... More than a few black students unquestionably suffer some degree of discomfort from being beneficiaries of the admissions process (as do some athletes and legacies, even though they are generally less 'visible').").

204. See also infra Part III.B.I.

205. Sander, supra note 139 , at 369. 
cial science has disproved the notion that this discrimination 'engenders attitudes of superiority or, alternatively, provoke[s] resentment among those who believe that they have been wronged by the government's use of race," 206 is unsatisfying. More work can be done. As Krieger points out, although the findings supporting the stigma argument made by opponents of affirmative action "are complex, contradictory, and difficult to interpret,... [c]omplicating matters further is the unfortunate fact that most research on the self-derogating effects of affirmative action has focused on gender preference. Little empirical work has been done on the effects of preferential selection on minority self-evaluation."207

Scientific proof may not be necessary for a finding of injury in a standing analysis, especially since many agree that stigmatic harm exists. Indeed, although social science evidence that proves the harm exists would be helpful, for a court to rely on it could be dangerous. ${ }^{208}$ Nevertheless, more specific studies should be undertaken to bolster the narratives of injury the plaintiffs will bring to the courts.

\section{Causation: Is the Stigma Caused by Defendants?}

The second and third requirements for satisfying standing are that the plaintiff's injury be "fairly traceable to the defendant's allegedly unlawful conduct and likely to be redressed by the requested relief." ${ }^{209}$ These requirements, usually referred to as causation and redressability, are often intertwined in discussions in the case law-and for good reason. ${ }^{210}$ But while often read together, the Court has emphasized that these two requirements demand separate inquiries. ${ }^{211}$ In Allen, the Court expressed the reason for this separation: "Even if the relief respondents request"-in that

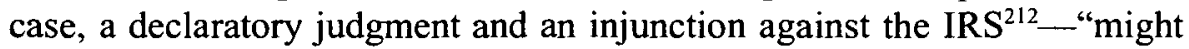
have a substantial effect on the desegregation of public schools, whatever

206. Grutter v. Bollinger, 539 U.S. 306, 373 (2003) (Thomas J., concurring in part and dissenting in part) (emphasis added) (quoting Adarand Constructors, Inc. v. Pena, 515 U.S. 200, 241 (1995) (Thomas, J., concurring)).

207. Krieger, supra note 174 , at 1259. "The evidence that does exist suggests that, at least under certain conditions, preferential selection may negatively affect women's self-evaluations, commitment, and task selection." Id. For Krieger's explication of the evidence, see id. at 1259-63.

208. See, for example, the "doll studies" and the controversial use of social science evidence in Brown v. Board of Education, 347 U.S. 483, $494 \mathrm{n} .11$ (1954), to show the psychological effects of racial segregation on black children.

209. Allen v. Wright, 468 U.S. 737, 751 (1984).

210. See infra text at notes 236-237.

211. Allen, 468 U.S. at 753 n.19. But see Gene Nichol, Abusing Standing: A Comment on Allen v. Wright, 133 U. PA. L. REv. 635 (1985) (criticizing the separation of causation and redressability). Accordingly, although some of the issues in the causation section can be seen as redressability issues (and vice versa), the inquiries must be separated. It is useful at this point to remind readers that Part III.A aims to use standing as a register for clarifying issues and is not primarily meant to be a formal analysis of standing doctrine.

212. See Allen, 468 U.S. at 746-47; see also supra text at notes 191-193. 
deficiencies exist in the opportunities for desegregated education for respondents' children might not be traceable to IRS violations of the law." 213 In other words, even if ruling against the defendant can remedy the injury, the defendant must have caused the injury in the sense that the harm is "fairly traceable" to its conduct.

\section{a. The Public Advocacy and Obvious Data Regarding the Effect of Affirmative Action on Minority Admissions}

Even if the university considers race, is stigmatic harm "fairly traceable" to what is simply differential treatment of some applicants by the university? Alas, due to the qualifications (under traditional criteria of merit) of many minority applicants, the differential treatment causes a large spike in minority admissions and enrollment figures at selective universities. For admission to selective undergraduate institutions, Bowen and Bok estimate that "the overall black probability [of admission] under a raceneutral procedure would be roughly half the white probability"214 _ a figure "remarkably similar" to the actual effects from the University of California at Berkeley's switch to a race-neutral standard for the class applying for admission for the fall of $1998 .^{215}$ Likewise, it is a sad though widely acknowledged fact that the number of enrolled students from certain minority groups would drop precipitously if affirmative action were ended. For example, Bowen and Bok "estimate that the adoption of a strict race-neutral standard would reduce black [undergraduate] enrollment at these academically selective eolleges and universities by between 50 and 70 percent."216 The reduction in minority enrollment at Berkeley's Boalt Hall School of Law after the enactment of Proposition 209 was even more dramatic. ${ }^{217}$

\section{Allen, 468 U.S. at 753 n.19.}

214. BOWEN \& BoK, supra note 69 , at 32 .

215. See id. at 32-33 ("[1]n this 'real time' case, as in the hypothetical results we obtained for the ["College and Beyond" database] schools, race-neutrality reduced the overall black probability of admission to almost exactly half the white probability.").

216. Id. at 50-51; see also id. at 51 ("According to these estimates, if blacks had been admitted in the same proportions as whites within each SAT interval (our definition of race-neutrality), black matriculants in 1989 would have constituted no more than 3.6 percent of the entering classes at these schools... [T]he most selective schools would experience the largest drops in black enrollment. The proportion of black students in these institutions would decrease from about 7 percent to roughly 2 percent of total enrollment.").

217. See Rachel F. Moran, Diversity and its Discontents: The End of Affirmative Action at Boalt Hall, 88 CALIF. L. REv. 2241, 2246-47 (2000) ("In 1996, the last year in which affirmative action was permissible, the admissions process produced a class of 263 students, which included 20 Blacks, 28 Latinos, 4 Native Amcricans, and 38 Asian Americans. Together, these groups accounted for thirtyfour percent of the students in Boalt's entering class. In 1997, the first year in which affirmative action was abolished, the change was dramatic. The new admissions process yielded a group of 243 students, of whom none were Black, 7 were Latino, none were Native American, and 32 were Asian American."); Andrea Guerrero, Silence at Boalt Hall: The Dismantling of Affirmative ACTION ix (2002) ("In my three years at Boalt, I watched the law school as it was forced to dismantle its affirmative action program - a program from which $I$ had benefited-and 1 watched the numbers of 
This data showing that racial preferences account for the admission and eventual enrollment of so many of the minority students at selective universities is significant both because the figures are striking and because they are public. University officials themselves admit the effect affirmative action policies have on the number of racial minorities admitted. Indeed, they not only admit this, but they and other affirmative action advocates wield it as a rhetorical weapon to rally support for preferential policies. They were vocal before the Miehigan decisions were handed down that without race-based affirmative action, the admission and enrollment of minority students would drop by a large amount. ${ }^{218}$ Their point is unfortunately true-even with race being taken into account as "one of many" factors as it must be (and ostensibly has been) since Bakke. ${ }^{219}$

The effect of affirmative action is public and, in the case of the most selective universities in California and Texas, the effect of ending it is already visible. People cannot help but take from this the lesson that affirmative action policies cause the admission of many, if not most, of the racial minorities on college campuses. Observers cannot be faulted for listening to those who advocate for affirmative action when they say that minority enrollment is at stake, for remembering this fact, and for internalizing the (factually correct) belief that qualifications must be different for many of these admitted minority students. Thus, the existence of a university's affirmative action admissions plan can cause one to rationally question an enrolled person of color's relative qualifications - not because this minority student is "unqualified" in an absolute sense, but because of the striking evidence and vigorous public advocacy regarding the importance of racial preferences for minority admission rates.

\section{b. Checking the Box: There is No Real Choice}

Is the stigmatic harm to the minority student "fairly traceable" to the university's consideration of race if students can choose whether to indicate their race on their application forms? On the University of Michigan's 2004-2005 application form for undergraduate admissions-the form that was created after the Gratz decision required the university to make revisions - -students have two main openings to indicate their race. The first is the familiar list of races and ethnicities: the form asks applicants to check the box that describes them. The application explicitly states that checking

minority students plummet."). Note that Moran's figures refer to the number of students who enrolled from that year's admitted-students pool; Guerrero is referring to the number of minority students with whom she attended law school.

218. See, e.g., Mary Sue Coleman, Editorial, No Time for Colorblindness, Wash. Post, Dec. 15, 2002, at B07 ("A ruling overturning Bakke could result in the immediate re-segregation of our nation's top universities, both public and private."). Coleman was and is the president of the University of Michigan.

219. See also infra Part III.C.1. 
a box is optional. ${ }^{220}$ The second is a required short-answer question that asks how students would contribute to the diversity of the university community. ${ }^{221}$ Though the second question gives an opening to discuss race, mentioning one's race in the essay is optional. Because the application makes identifying one's race optional, applicants who do mention race are doing so on their own (or with a parent's help). How does the university's admissions procedure stigmatize based on race if the only way the applicant's race is mentioned (and therefore potentially factored into admissions decision-making) is by his or her choice?

Indeed, if a minority applicant chooses not to check the box ${ }^{222}$ and is nevertheless admitted, he or she should not experience stigma related to self-doubt (at least initially). But, like Baker (the hypothetical plaintiff from the discussion of injury above), the "stigma of inferiority" still applies. All admitted minority students, whether or not they choose to check the box, can claim they are "tarred as undeserving" by the existence of the policy. Indeed, an applicant who does not check the box is in some respects a more ideal plaintiff because any stigma of undeservingness that may attach to her-and any self-doubt as a result-would have nothing to do with an action she herself took, aside from applying and enrolling in the first place.

For some racial minorities, it is a difficult decision whether or not to check the race box. Unfortunately, "all are tarred as undeserving." ${ }^{\text {"223 }}$ In terms of this kind of stigma, it does not matter whether one checks the box. As Justice Thomas remarked in Grutter, "It is uncontested that each year, the Law School admits a handful of blacks who would be admitted in the absence of racial discrimination. ... Who can differentiate between those who belong and those who do not?" 224 Putting aside his somewhat incendiary language of "belong[ing]," Thomas's point is instructive: differentiation at the most selective institutions between people like Adams and the "handful"225 like Baker is, at the very least, quite difficult. As a result, it is foolish not to check the box with the hope of avoiding being stigmatized.

220. See University of Michigan, 2004-2005 APPLICATION fOR UNDERGRAdUATE AdMisSion 8, http://www.admissions.umich.edu/applying/2004-05a_UMapplication_Acr4.pdf (last visited Sept. $10,2005)$.

221. See id. at 11 ("At the University of Michigan, we are committed to building a superb educational community with students of diverse talents, experiences, opinions, and cultural backgrounds. What would you as an individual bring to our campus community?").

222. For the remainder of this section, 1 will use the "check the box" language as shorthand for the general option of stating one's race in the application.

223. Grutter v. Bollinger, 539 U.S. 306, 373 (2003) (Thomas J., concurring in part and dissenting in part).

224. Id.

225. Aside from the most elite small colleges and graduate programs, "handful" if taken literally is clearly an understatement of the number of admittees-though not by much. See supra note 217; see generally supra Part III.A.2.a. 
In his Adarand dissent, Justice Stevens made the point that minorities can simply "opt out" and therefore find relief from stigmatization. ${ }^{226}$ But unless one is solely concerned with eliminating self-doubt, ${ }^{227}$ any student applying to a selective university that employs racial preferences in choosing whom to admit and who is of a racial group that is known to benefit from such preferences cannot effectively "opt out" in the form of not checking the box. To those who say that "simple economic analysis would suggest that minorities generally would decline to participate in affirmative action programs if the effects of stigmatization outweighed the benefit of obtaining the job in question or being admitted to law school,"228 the response is to question the premise: if "minorities are utility maximizers,"229 they ought to continue to check the box, for "declin[ing] to participate"230 in the sense of also being able to opt out of the stigmatic harm associated with participation in the policy is impossible. Even those who want to choose not to accept the tradeoff (i.e., some stigma in return for access) will be stigmatized. Thus, there is no real choice whether to check the box; the reason one should not opt out of checking the box is that one cannot opt out of most stigmatizing effects of the policy. ${ }^{231}$

In practice, only the university can solve the problem-by removing from its application any questions that ask for an applicant's race. The university, however, surely wants the checkbox there and is quite pleased when an applicant indicates on it that he or she is a member of a minority group. Bowen and Bok recount the following story in their book, The Shape of the River:

226. Adarand Constructors, Inc. v. Pena, 515 U.S. 200, $247-48$ n.5 (1995) (Stevens, J., dissenting) ("No beneficiaries of the specific program under attack today have challenged its constitutionalityperhaps because they do not find the preferences stigmatizing, or perhaps because their ability to opt out of the program provides them all the relief they would need."); see also Rubenfeld, supra note 127, at 448 ("Let's define a standard affirmative action plan as one that offers preferential treatment to minorities in the allocation of desirable opportunities, but leaves them free to opt out of this preferential treatment if they so choose. Such a plan is not paternalist. On the contrary, if a govemment official prevented minority group members from taking advantage of such a plan, claiming that affirmative action was against their own interests, that would be an instance of racial paternalism.") (first emphasis added).

227. Even then, it is questionable whether self-doubt can be avoided for long, with one being continually burdened with the other-stigma of being "tarred as undeserving."

228. Halaby \& McAllister, supra note 106, at 273.

229. Id.

230. Id.

231. Although the choice to opt out would be a meaningful one if enough minority applicants chose not to check the box, this is unlikely to happen beeause of a collective action problem. Assuming that enough minority applicants would decide on their own that the stigmatie harms are great enough that they would like to opt out-assuming a "critical mass," if you will, of racial minorities do not like the box or the stigma (or both) - it is a collective action problem in that there is a check-the-box norm that would be nearly impossible to destabilize without some sort of coordinated, concerted, and public action. Without coordination, the collective action problem makes it so that the few who may want to not check the box cannot do so and be free of stigmatic harm. 
When a distinguished black educator visited the Mellon Foundation, he noted, with understandable pride, that his son had done brilliantly in college and was being considered for a prestigious graduate award in ncuroscience. "My son," the professor said, "needs no special consideration; he is so talented that he will make it on his own." His conclusion was that we should be indifferent to whether his son or any of the white competitors got the particular fellowship in question. We agreed that, in all likelihood, all of these candidates would benefit from going to the graduate school in question and, in time, become excellent scientists or doctors. Still, one can argue with the conclusion reached by the parent. "Your son will do fine," another person present at the meeting said, "but that isn't the issue. He may not need us, but we need him! Why? Because there is only one of him.,"232

Likewise, the university has a strong interest in maintaining its raceconscious admissions policies and thus has a strong interest in making sure most students of color declare their race-even if, as they acknowledge sometimes is the case, an applicant "may not necd us." Even if the applicant may not want the university to consider his race, the university hopes the applicant checks the box, and it certainly has no interest in doing anything to discourage him from doing so.

\section{Redressability: Is Stigma the Tip of the Societal Racism Iceberg?}

This Section addresses the challenge that, as Lawrence and Matsuda put it, "[t]he stigmatizing beliefs about people of color, the assumptions of incompetence and inferiority, have their origin not in affirmative action programs, but in the cultural belief system of white supremacy. ${ }^{.233}$ Robin Barnes, reviewing Stephen Carter's book on his expericnce being an "affirmative action baby," questions the lineage of the stigmatic harm Carter expressed. Barnes "contend[s] that it is the nation's longstanding ideology of white supremacy, and not affirmative action, that explains" stigmatization. ${ }^{234}$ What harm has a university's affirmative action program caused if the stigmatic harm comes not from its program but from societal racism?

232. BOWEN \& BoK, supra note 69, at 283 (emphasis in the original). This squares with diversity for society, discussed supra Part 1.B.2, and the university's interest in making society's leadership cadre diverse. The above quotation is immediately followed by Bowen and Bok's recognition that, " $[t]$ hat mild exaggeration notwithstanding, the relative scarcity of talented black professionals is all too real. It seemed clear to a number of us that day, and it probably seems clear to many others, that American society needs the high-achieving black graduates who will provide leadership in every walk of life." Id.

233. LAWRENCE \& MATSUDA, supra note 26, at 127.

234. Robin D. Barnes, Politics and Passion: Theoretically a Dangerous Liasion, 101 YALE L.J. 1631, 1638 (1992) (reviewing Carter, supra note 136, and PATricia J. Williams, The Alchemy of RACE AND RIGHTS (1991)). 
Although this Comment now moves to the third prong of the standing inquiry, this is an issue that touches on both causation and redressability. Does the university cause the stigma, or is the stigma a product of society-specifically, societal racism? In the Allen case discussed at some length above, the Court found that the injury resulted from the "independent action of some third party not before the court" and thus did not meet the causation standard of being "fairly traceable" to the defendant's conduct. ${ }^{235}$ That is a causation question. Similarly, asking whether a societal "cultural belief system" or "longstanding ideology," rather than the university, caused stigmatization is a causation question. Yet an answer seems quite difficult to obtain if asked in this way. Instead, the question can be reframed as a redressability inquiry: would removing affirmative action reduce stigmatization? If a favorable ruling for the plaintiff could reduce stigmatization in this thought experiment, then affirmative action must be playing a role in the stigmatization of racial minorities-either on its own or in addition to societal racism.

Redressability depends on whether a favorable court ruling would be likely to remedy the plaintiff's injury. ${ }^{236}$ In part to guard against courts issuing advisory opinions, this requirement also exists to make sure a court ruling would be likely to benefit the plaintiffs. To satisfy redressability, a plaintiff "need not show that a favorable decision will rclieve his every injury"-only that it will "relieve a discrete injury to himself." 237 Thus, a plaintiff need not show that a favorable ruling would remove all racism or perceptions of inferiority.

Instead, the question is whether a favorable decision for the plaintiffs would make them any less stigmatized-or, in the alternative, whether affirmative action promotes more stigmatization than would exist absent such a policy. ${ }^{238}$ Does affirmative action create its own stigma or exacerbate existing stigmatization such that eliminating such a policy would remove its stigma or reduce existing stigmatization? The question, then, is one of net, not gross, and the inquiry proceeds at the margin.

Indeed, many opponents of affirmative action do not dispute the pernicious existence of societal racism. Shelby Steele acknowledges that "[t]he accusation black Americans have always lived with is that they are inferior-inferior simply because they are black. And this accusation has been too uniform, too ingrained in cultural imagery, too enforced by law,

\footnotetext{
235. Allen v. Wright, 468 U.S. 737, 757 (1984) (citations and quotation marks omitted).

236. Id. at 751 (stating that plaintiff's injury must be "likely to be redressed by the requested relief').

237. Larson v. Valente, 456 U.S. 228, 244 n.15 (1982)

238. Cf. Rubenfeld, supra note 127, at 446 ("Does affirmative action "in fact promote notions of racial inferiority and lead to a politics of racial hostility'? Without doubt. Of course, affirmative action's critics tend to forgct that the relevant question on this point is whether affirmative action fosters more racial hostility and stcrcotyping than would exist without it.") (footnote omitted).
} 
custom, and every form of power not to have left a mark."239 What Steele laments is that the "myth of black inferiority" is "sadly reinforced for many black students by affirmative action programs." 240 Even an affirmative action opponent like Steele admits that a stigma from societal racism has always existed. But he argues that affirmative action adds to the mark, or creates an additional mark. Robin Barnes disagrees, saying that "some will presume that Black professionals have advanced because of affirmative action, but it is doubtful that affirmative action has augmented the degree to which they are scrutinized and unclear that it weakens their chances of being named among the best."241 Barnes and Steele seem to agree about the existence of the problem of societal racism; what they disagree about is whether there is marginal harm. ${ }^{242}$ The issue is whether the "stigma" associated with affirmative action reflects the problem of societal racism, or whether affirmative action exacerbates and adds to that problem such that eliminating the policy would eliminate the augmentation.

Some social science bears out the notion that affirmative action exacerbates existing prejudice. Admittedly, some of the literature on this point is less probative than is ideal. Although we need not accept the overall conclusions Paul Sniderman and Thomas Piazza draw in their book, The Scar of Race, ${ }^{243}$ a study they discuss is worth mentioning as at least supportive of the exacerbation argument (and thus satisfying the redressability requirement). The authors cite an experiment that posed two questions to a random sample of white people in Lexington, Kentucky. One question asked whether one favored or opposed an affirmative action policy. ${ }^{244}$ The second question presented a number of descriptions-positive and negative-of black people, asking subjects whether they agreed or disagreed with each one. ${ }^{245}$ Half the pool was asked the first question first, and the other half was asked the second question first. This study, commonly

239. STEELE, supra note 173 , at 133 (emphasis added).

240. Id. at 133-34 (emphasis added); cf. CARTER, supra note 136, at 3 ("[E]very professional who is not white is subjected to that extra degree of scrutiny that attaches to those who are suspected of having benefited, at some point in the development of their careers, from a racial preference.") (emphasis added).

241. Barnes, supra note 234, at 1641 (emphasis added).

242. 1 use "marginal" as economists do-to refer to change at the margins-and not to imply that the harm is trivial.

243. See generally Paul M. Sniderman \& Thomas Piazza, The Scar of Race (1993).

244. The question presented a quota for black people to get state government jobs. Although never using the word "quota" (it instead mentioned jobs being "reserved" for blacks), it did mention that they would get the jobs "even if their scores on merit exams are lower than those of whites who are turned down for the job." See id. at 102. The question's mention of the program being in a "nearby state" was designed to eliminate or minimize self-interest - "to ensure . . that people do not object to affirmative action because they will themselves be cut out of a job." Id. However, the fact that this question dealt with employment quotas (while university affirmative action programs cannot use quotas) and the question's explicit mention of the potential of lower merit are both unfortunate because these features may make the experiment less helpful generally.

245. Id. at 103. 
referred to as the "mere mention" experiment, showed that those who were asked to respond to the issue of affirmative action first were significantly more likely to say that black people are "irresponsible" and "lazy."246 Of those who had not first heard the question about affirmative action, the percentage of people who agreed with the statement "Blacks are irresponsible" was $26 \%$; of those who had first been asked "only one" question about affirmative action, $43 \%$ agreed. Similarly, the "mere mention" of affirmative action caused the percentage that agreed with the statement "Blacks are lazy" to rise from $20 \%$ to $31 \% .{ }^{247}$

What are we to make of this? First, let there be no doubt: the $26 \%$ and $20 \%$ figures are based on pernicious stereotypes. However, the marked rise described above shows that, writ large, the mention of affirmative action triggers or exacerbates these stereotypes. ${ }^{248}$ Admittedly, the study has its shortcomings. ${ }^{249}$ Its use here should not be interpreted as a showing of proof. But a study like this can support the contention that although the existing stigma of societal racism and stereotyping is a very real problem, affirmative action may augment it-such that removing affirmative action may redress the marginal increase in stigmatization. ${ }^{250}$

Stigmatic harm by the university does not arise from the simple recognition of present inequalities and inequities in society, including those along racial lines. But the university, by using an admissions system based at least in part on one of those axes of inequality - and particularly one so visible-may be causing some stigmatization and exacerbating existing stereotypes. $^{251}$ The point for this Section's purposes is that, regardless of

246. See id. at 103-04. But see supra note 244 (describing some flaws of the affirmative action question).

247. See Sniderman \& Piazza, supra note 243, at 103-04.

248. Even if it just triggered the expression of that view-in other words, even if an equal percentage of respondents at base hold the same views about black people, and the mention of affirmative action only signaled to respondents that they had permission to be honest in their expression of those views--that increase in the form of a signaling effect is still a marginal harm. Similarly, it would be significant even if the effect was only to solidify one's previously hesitant or loosely held prejudices.

249. See Charlotte Steeh, Book Review, 59 Pub. OpINIon Q. 316, 318 (1995) (reviewing SNiderman \& PiazZa, supra note 243) (describing the "mere mention" experiment as "considerably weakened" due to its sample size of only 236 participants compared to 1113 for the overall survey); supra note 244; see also Steeh, supra, at 318 ("Although The Scar of Race has not succeeded in discrediting the concepts of the new racism, it has advanced ideas that ought to be tested systematically.... The idea that affirmative action policies are so universally unfair that they trigger antiblack feeling - the finding from the 'mere mention' experiment-needs more careful exposition lest we all conclude that the American creed is grievously split and individualism does, after all, foster prejudice.").

250. One need not agrce with the authors' crude characterization that the study "demonstrat[ed] that dislike of particular racial policies can provoke dislike of blacks, as well as the other way around." See Sniderman \& PIAZza, supra note 243, at 104.

251. See also Krieger, supra note 174 , at 1263 (noting that those who criticize affirmative action policies for reinforcing stereotypes argue that "[b]ecause prefcrence permits people to attribute preferred group members' success to factors other than merit, affirmative action reinforces stereotypic 
whether some stigma existed before, if removing racial preferences in admissions policies would reduce total stigma (or at least not activate or exacerbate another stigma), that net gain is significant to showing potential redressability.

Even if affirmative action exacerbates existing stigmatization, affirmative action has its benefits. The question, then, is whether the benefits sufficiently outweigh the harms. This question goes to the merits of our hypothetical case and thus is our signal to leave the register provided by the standing inquiry.

\section{B. "Compelling Interest": Weighing Benefits and Harms}

Sections B and C will look at the new, post-Grutter calculus for affirmative action in higher education with a minority plaintiff asserting a claim that a university's use of racial preferences in its admissions program causes stigmatic injury. Section B will examine the "compelling interest" prong of strict scrutiny with respect to the diversity interest for racial minorities. This Section does not investigate whether there is stigmatic harm. Nor does it analyze definitively whether the benefits to racial minorities outweigh the harms, or vice versa. ${ }^{252}$ Rather, it will address some of the kinds of inputs and evidence courts may consider using when they weigh the benefits that accrue to racial minorities from affirmative action against the harms associated with stigmatization.

\section{Narratives that Weigh Benefits and Harms}

One kind of source courts may consider is the narrative of someone arguing that affirmative action's harms outweigh its benefits, and vice versa. The kind of narrative discussed in this Section is not exactly the one we have already seen (stigmatized minorities saying they feel stigmatized). Although most of the narratives in this Section are from people of color, this Section instead examines narratives that weigh the harms against the benefits and then considers briefly what courts might do with these competing narratives.

\footnotetext{
assumptions of outgroup inferiority and thus hampers stereotype change.") (emphasis added). Krieger observes that "[i]ndeed, the weight of empirical evidence reasonably supports the view that using preferences tends to exacerbate subtle forms of intergroup bias in the evaluation of affirmative action beneficiaries." Id . (emphasis added). The exacerbation of stereotypes may also foster the more psychological stigma of self-doubt, in the form of what is now referred to as "stereotype threat." See Claude M. Steele \& Joshua Aronson, Stereotype Threat and the Intellectual Test Performance of African-Americans, 69 J. Personaltry \& Soc. Psychol. 797 (1995) (describing stereotype threat). There being a "critical mass" might mitigate minorities' feelings of being observed, but it seems equally plausible that the stated partial rationale of their presence as necessary for "visibil[ity]" and its future role-model potential can reinforce those feelings. Cf. supra Part I.B.3.

252. Indeed, such a definitive conclusion supporting either position at this point in time shouldeven after so many years of fervent debate, litigation, and scholarship-immediately strike one as inherently suspect.
} 
With rare exceptions, ${ }^{253}$ the arguments from minorities who are opposed to affirmative action on the basis of stigmatic harm do not explicitly indicate that the harm outweighs the benefits. This is no doubt due in part to the inherent assumption that a person of color opposed to affirmative action who makes a sustained argument about stigmatic injury presumably believes that the harms outweigh the benefits. Supporters of affirmative action, when they mention stigma, often do so as an acknowledgment of the harm but then indicate that, to them, that harm is outweighed by affirmative action's benefits. But opponents rarely explicitly state that "the harm outweighs the benefits" because such a claim is often already implicit in their arguments.

Thus, it is true that Thomas's Grutter opinion, as Professor Dorf puts it, "fails to consider... arguments that affirmative action-though stigmatizing in the eyes of some-is still worthwhile." ${ }^{254}$ Dorf found this "most disappointing," but while it does seem obvious that "Justice Thomas plainly disagrees" that affirmative action's benefits outweigh the harms, Thomas was writing a dissenting opinion and was not doing the math in the new calculus himself. In part, this is because Thomas, though making a legal argument, also had to testify about the stigmatic costs since no litigant had done so (because Grutter was an example of the traditional affirmative action litigation paradigm). Supporters of affirmative action often ask, "[W]hat people are in the room because of affirmative action, and what would we lose if they were no longer there?"255 The concerns brought forward by Thomas and the others discussed earlier in this Comment pose their questions from a differcnt vantage point-from that of those brought into the room by affirmative action and those in the room who are assumed to be there because of affirmative action. Thomas's opinion does much even if it does not explicitly weigh costs and benefits. Thomas spoke from the position of a racial minority in the room who is wondering if being brought into the room in this way or simply being in the room with this method existing is harmful to him, and said, quoting Frederick Douglass, "Let him alone!"256

With such a forceful quotation to open his opinion, there should not be any doubt where Thomas would come out if he were to formally weigh benefits and harms. ${ }^{257}$ Nevertheless, even if stigma is a cost borne by

253. E.g., Thomas Sowell, Are Quotas Good for Blacks?, CommEnTARY, June 1978, at 39, 43 ("The message that comes through loud and clear is that minorities are losers who will never have anything unless someone gives it to them. The destructiveness of this message - on society in general and minority youth in particular-outweighs any trivial gains that may occur here and there.").

254. Dorf, supra note 9.

255. LAWRENCE \& MATSUDA, supra note 26, at 7.

256. Grutter v. Bollinger, 539 U.S. 306, 350 (2003) (Thomas, J., concurring in part and dissenting in part); see also supra note 96.

257. Thomas quoted the next sentence of Douglass's statement: "Your interference is doing him positive injury." Grutter, 539 U.S. at 350 (Thomas, J., concurring in part and dissenting in part). lt is 
admitted minorities, it is possible that it does not outweigh the benefits that accrue to them. Therefore, the stigma argument that Thomas and others make is an input into the calculus, but its appearance does not end the calculating. Justice O'Connor did not grapple with the harms to racial minorities in her majority opinion, but the bar should be higher when arguing that a program often assumed to help racial minorities actually harms them (and harms them more than it helps them). If Justice Thomas (or another Justice) is to write a majority opinion striking down an affirmative action program based on its stigmatic costs, he ought to explicitly weigh whether racial minorities, having weighed the benefits against the harms, actually believe, as he does, that stigmatization trumps what one must acknowledge-and what the Court has already acknowledged in Grutter - are very real benefits.

Indeed, some narratives of people of color that explicitly weigh the benefits and harms show a deep ambivalence about whether one side outweighs the other. Take, for example, the conflicted statement of former Duke University student McKinley Melton, who as a college senior said:

I'm personally not a big fan of affirmative action. I don't really like it. I mean, I support it, because I believe in its necessity. But I don't much care for it, because there is that stigma attached. There is that sense that if you are African American, if you are Hispanic, if you come from a certain background, the only way you could get into college is through affirmative action. ${ }^{258}$

Melton, like many others, is conflicted: he supports affirmative action and "believe[s] in its necessity," but does not like it. ${ }^{259}$ In another vein is Roland G. Fryer, Jr., an assistant professor of economics at Harvard University who was profiled by The New York Times Magazine at the age of twenty-seven. Fryer, a rising star in his field, said, upon being asked how it felt to be one of the few blacks in his field, "I'd rather be on an absolute standard, where being black doesn't matter." ${ }^{260}$ Fryer believes Harvard did not hire him based on affirmative action, and the author reports that if Fryer "found out otherwise, he said, he would quit tomorrow." ${ }^{261}$ Nevertheless, "[h]e is neither opposed nor in favor of affirmative action in the absolute; to him, the more relevant factors are the timing and degree of its implementation. But like DuBois, he can always feel an

\footnotetext{
possible that the reference to "positive" injury means that Thomas believes affirmative action is doing net positive injury, in the sense that the harms outweigh the benefits. Admittedly, this interpretation is a stretch.

258. Robert J. Bliwise, Reaffirming Affirmative Action, DukE MAG., Sept.-Oct. 2003, available at http://www.dukemagazine.duke.edu/dukemag/issues/091003/action l.html.

259. Id.

260. Stephen J. Dubner, Toward a Unified Theory of Black America, N.Y. Times, Mar. 20, 2005, § 6 (Magazine), at 54.

261. Id.
} 
accusation hovering."262 Melton's and Fryer's narratives are clearly different, but both reveal that, at least for some racial minorities, the weighing of benefits and harms is quite difficult.

But others are quite firm in their beliefs that the access affirmative action provides is worth the costs. Professor Christopher Edley's costbenefit analysis, for example, recognizes that "affirmative action has a cost; that part of the cost is the risk of stigma," but he states that "the stigma I may suffer is a small price compared to the price I would pay if I faced closed doors, or compared to the price paid by crusaders a generation ago who faced vilification, mobs, beatings, and even murder."263 Edley takes a more historical view in his weighing of the harm of stigma against the benefits of affirmative action and the legacy of black Americans, and he concludes with a judgment that "[i]t is hubris of the most unattractive sort for minorities and women of my generation to complain about our comparatively trivial burdens in carrying progress forward."264

Maybe it is "hubris," and maybe it is not. Different people do the math differently. One day the Court may do the math, and although individual opinions about the cost-benefit outcome may be persuasive, as of yet no one argument trumps the others. Whether the benefits outweigh the harms is not up to "elites," but neither is it solely up to the individual plaintiff who feels at risk of imminent stigmatization. ${ }^{265}$ The plaintiff's assertion of stigmatic injury may be enough to satisfy standing, but in a compellinginterest analysis under strict scrutiny, it is for the Court, not any of these individuals, to decide whether the benefits outweigh the harms. ${ }^{266}$ Competing narratives provide important evidence for the Court-and

\footnotetext{
262. Id.

263. EDLEY, supra note 120 , at 81 .

264. Id.

265. However, note that a common formulation of the benefit-harm question does not apply to certain plaintiffs. Erwin Chemerinsky raises the question in this way: "[T]he question of stigma is a complicated one. Are blacks, as a group, better off having more spaces in colleges and universities with the danger of stigma; or would they be better off with few slots, but less stigma?" Erwin Chemerinsky, Making Sense of the Affirmative Action Debate, 22 Oню N.U. L. REv. 1159, 1175 (1996). To Chemerinsky, the answer is not clear: "Affirmative action might create stigma. Yet at least under some circumstances, minorities are probably much better off with more jobs or positions in schools even though the cost is such stigma." Id. Others see the scales tip the other way. Chemerinsky's question is about blacks "as a group." But the issue of balancing the stigma versus not being admitted does not apply to individual plaintiffs like the hypothetical Baker from Part lII.A.1,b, who would be admitted anyway.

266. Neither is it for legislators to decide. In his dissent in Adarand, Stevens referred to Thomas's stigma argument and said, "I am not persuaded that the psychological damage brought on by affirmative action is as severe as that engendered by racial subordination. That, in any event, is a judgment the political branches can be trusted to make.... If the legislature is persuaded that its program is doing more harm than good to the individuals it is designed to benefit, then we can expect the legislature to remedy the problem." Adarand Constructors, lnc. v. Pena, 515 U.S. 200,248 n.5 (1995) (Stevens, J., dissenting). Stevens disagrees with the use of strict scrutiny. Although legislators' judgment may be good evidence for the Court, under strict scrutiny, Stevens's judgment-and those of his fellow Justices - carry more weight than the "political" branches-rightly or wrongly.
} 
importantly, they provide rhetorical force for the Court's opinions-but they should not and likely will not be enough. Rather than arbitrarily choosing to rely on one narrative over others, the Court ought to ground its choice in more aggregated, comprehensive data.

\section{Social Science}

Competing narratives can only tell us so much. Establishing a compelling interest or lack thereof based on a choice of narrative or an ad hoc balancing of them would be open to much criticism. In some ways, it would be ideal if social science could tell us if there is a point at which minorities' burdens from affirmative action become greater than the benefits (and vice versa). Such a study-a cost-benefit analysis specifically with regard to racial minorities-may help inform whether an affirmative action policy of any kind is sufficiently compelling for racial minorities. ${ }^{267}$ Even if there were such an interest, perhaps a study could also tell us whether certain features of affirmative action policies could be adjusted to minimize stigmatization. ${ }^{268}$

However, it may be that because the nature of stigmatization is in many ways amorphous, a social science study cannot weigh that harm against the benefits. There have been studies performed that look particularly at outcomes of minority students (and former students) and evaluate whether they benefit from affirmative action, but these studies do not really analyze stigmatization. ${ }^{269}$ It is possible social science cannot determine whether the subjects of affirmative action are better or worse off in the sense of whether the stigmatic harms outweigh the benefits. At the very least, apparently no study has yet done so.

\section{Polls and Surveys}

Polling is in some respects a subset of social science, but it can be a way to gather and measure the views of those who may know best: the supposed beneficiaries of affirmative action. As Bowen and Bok have written, "The judgment that has to be made is whether, at the end of the day, it

267. But see supra note 208 and accompanying text.

268. See infra Part III.C.

269. For example, studies have been performed on minorities' post-law-school incomes and career satisfaction compared to those of whites. See, e.g., David L. Chambers et al., Doing Well \& Doing Good: The Careers of Minority and White Graduates of the University of Michigan Law School, 19701996, http://www.Iaw.umich.edu/NewsAndlnfo/lawsuit/survey.htm (Iast visited Sept. I0, 2005) (comparing white and minority University of Michigan Law School alumni). But the success of black graduatcs does not mean this benefit outweighs any stigmatization, aside from the fact that the "cxpanding self-doubt" did not in fact relatively impair minorities' career achievements. (Though that is a claim that is sometimes made by opponents of affirmative action because of its stigmatization, see STEELE, supra note 173 , at 116-17, that the stigmatization has not caused such an outcome does not mean that the stigmatization does not exist.) The Sander study also does not deal with stigmatization. See supra note 142. 
is worth accepting these costs," including stigmatization, "which are all too real, in exchange for the benefits received."270 They conclude-and I agree-that "[t]he black matriculants themselves-who are, after all, the ones most affected by any stigmatizing effects-are presumably in the best position to weigh the pros and cons."271 Polling, in the form of conducting a targeted and specific survey, can serve to aggregate individual narratives that weigh benefits against costs.

Some will question what polling would accomplish. After all, since racial minorities as a group seem to strongly support affirmative action, it must be more beneficial than harmful; otherwise, they would be currently lobbying for its swift removal. ${ }^{272}$ Yet this assumes that the group's "leadership" has not diverged from the interests of its members. ${ }^{273}$ Polling the relevant population can mitigate the danger of the elite's opinions being incompletely influenced by or simply divergent from those whom they may purport to represent.

However, recall Justice Powell's words in Bakke that "[n]othing in the Constitution supports the notion that individuals may be asked to suffer otherwise impermissible burdens in order to enhance the societal standing of their ethnic groups."2774 Similarly, it would be most improper for the Court to rule on a practice's constitutionality based on a poll or survey of a law or policy's popularity or support. Courts should generally not factor polls into a strict scrutiny analysis. ${ }^{275}$ However, in the hypothetical suit discussed in this Comment, a poll may be useful in that it reveals facts. If racial minorities do not believe they are helped (more than harmed) by affirmative action, and if we believe that their beliefs are accurate and that they are in the best position to know, then the conventional wisdom that they are indeed benefiting is undermined. Additionally, stigmatic injurywhether it exists and whether its harms outweigh a policy's benefits-is bound up with the public's perceptions and the self-perceptions of those potentially being stigmatized. Polls that can isolate stigma can illuminate how weighty an issue and how serious a harm it is generally, and such

270. BOWEN \& BoK, supra note 69 , at 265.

271. Id.

272. See also T. Alexander Aleinikoff, $A$ Case for Race-Consciousness, 91 Colum. L. Rev. 1060, 1091-92 (1991).

273. Cf. Halaby \& McAllister, supra note 106, at 273 ("For the same reasons, one would not expect minorities as a group to advocate politically for affirmative action programs if the result is a net loss in group utility, assuming that the group's leaders' interests coincide with those of a majority of the individual members.").

274. Regents of the Univ. of Cal. v. Bakke, 438 U.S. 265, 298 (1978) (opinion of Powell, J.).

275. On polls, strict scrutiny, and affirmative action, compare Gail L. Heriot, Essay, Strict Scrutiny, Public Opinion, and Affirmative Action on Campus: Should the Courts Find a Narrowly Tailored Solution to a Compelling Need in a Policy Most Americans Oppose?, 40 HARV. J. ON LEGIS. 217 (2003), with Lawrence Friedman, Essay, Public Opinion and Strict Scrutiny Equal Protection Review: Higher Education Affirmative Action and the Future of the Equal Protection Framework, 24 B.C. THIRD WORLD L.J. 267 (2004). 
determinations can then come into play when looking at how compelling specific cases are.

Of course, polls and surveys can be misleading and produce indeterminate conclusions. This indeterminacy arises in part because the questions often posed are too broad (for example, "Do you support affirmative action?") ${ }^{276}$ and the pools of the polls' subjects are not targeted enough. ${ }^{277}$ Although easier said than done, researchers should attempt to break out opinions on stigmatization and pose questions that isolate it against the benefits of affirmative action. Of course, while "those best positioned to know" may come down one way in the aggregate, the Court may ultimately decide to do the benefit-harm balancing differently in its examination of whether the interest underlying an affirmative action policy is sufficiently compelling. Justices may give more weight to specific narratives, particularly those of the plaintiffs. But by revealing facts, welldesigned surveys can serve to aggregate narratives and broaden the scope of who has voice in this constitutional decision-making process-beyond the prominent individuals, editorial writers, book authors, and pundits whose individual opinions we mostly already know.

\section{Narrow Tailoring to Minimize or Eliminate Stigmatic Harm}

If the Court's compelling-interest analysis in a case like my hypothetical finds that stigmatic harm outweighs the benefits of affirmative action such that the diversity interest for racial minorities is called into doubt, the Court may decide to find the rationale of diversity's benefits for racial minorities insufficiently compelling and stop there. But it also may decide to insist through a narrow-tailoring analysis that universities that want to use affirmative action programs consider or employ admissions policies or

276. A defense of asking racial minorities whether they support or oppose affirmative action is that such a question likely reveals whether they believe they are helped more than harmed by it, or vice versa, assuming their answers to survey-takers are accurate representations of their own beliefs. Yet "affirmative action" can mean many different things-referring to different procedures or other types of actions (for example, quotas versus preferences versus simply being proactive and making a conscious effort to not discriminate) and contexts (for example, contracting versus employment versus university admissions). "[S/urvey questions can achieve greater validity by dropping the words 'affirmative action' altogether and describing instead the content of a specific affirmative action policy." Charlotte Steeh \& Maria Krysan, Trends: Affirmative Action and the Public, 1970-1995, 60 Pub. OpInion Q. 128, 130 (1996); see also generally infra Part lli.C.

277. A substantial issue with polls for the purposes of this hypothetical case is that the relevant pool is uncertain. Should all racial minorities who purportedly benefit from affirmative action be asked? Only current minority college students and recent graduates? What about minority high-school students who are considering applying to college? Should all universities' minority applicants, students, and alumni be part of the pool? Or only those minorities seeking or having achieved admission to "selective" institutions of higher education? Or only those minorities applying to, attending, or having attended the specific university that has been sued? And is it possible or desirable to only ask those who would be or have been admitted without an affirmative action policy in place? 
other practices that eliminate the programs' stigmatization or make admission lcss stigmatizing. ${ }^{278}$

The Court in Grutter described four requirements a race-based affirmative action program must meet in order to satisfy the requirement that it be narrowly tailored. First, since "there are serious problems of justice connected with the idea of preference itself," 279 the program must not "unduly harm members of any racial group." 280 Second, there must have been a "serious, good faith consideration of workable race-neutral alternatives that will achieve the diversity the university seeks." ${ }^{281}$ Third, the program must be "limited in time." ${ }^{282}$ Finally, each applicant must be given "truly individualized consideration." 283

This Section examines very briefly some of the alternative means universities might consider using-means the Court might one day insist upon - that may reduce or climinate a policy's stigmatizing effects while still aiming at the goal of a diverse student body. Focusing on narrow tailoring makes a great deal of sense if the goal is to reduce stigmatization, for some evidence suggests that "stigma-related responses to the policy are not inevitable but may depend on the nature of the policy implementation procedures."284 Indeed, Professor Krieger's summary of the evidence on stigmatization is inconclusive because some studies' findings indicate that responses "vary considerably" depending on, among other things, "how specific policies are described and implemented."285 if the form of an affirmative action policy affects stigmatization-if specific forms may

278. It is possible that litigants need not wait for the Supreme Court to rule, however; as long as the current doctrine (in which the Court has found this diversity interest to be compelling) holds, courts may nevertheless consider striking down specific policies as not being narrowly tailored due to their stigmatic costs. But see supra Part 11.D. Under current narrow-tailoring doctrine, courts must first consider whether there has been a "serious, good faith consideration of workable race-neutral alternatives that will achieve the diversity the university seeks." Grutter v. Bollinger, 539 U.S. 306, 339 (2003). Reliance by courts on the university's own consideration (which is a controversial level of deference) and acceptance of "the diversity the university seeks" as the aim that must be satisfied gives universities more leeway to tailor their policies (and gives plaintiffs less ammunition to challenge such policies on narrow-tailoring grounds) than if the Court were to take another affirmative action case, consider stigmatic harm, and rule that the harm is so real and overwhelming that the Court will examine other possible means itself and not limit itself to achieving the same degree of diversity sought by the university.

279. Grutter, 539 U.S. at 341 (quoting Bakke, 438 U.S. at 298).

280. Id.

281. Id. at 339 . This "does not require exhaustion of every conceivable race-neutral alternative. Nor does it require a university to choose between maintaining a reputation for excellence or fulfilling a commitment to provide educational opportunities to members of all racial groups." Id. (quoting Wygant v. Jackson Bd. of Educ., 476 U.S. 267, 280 n.6 (1986); Richmond v. J.A. Croson Co., 488 U.S. 469, 509-10 (1989) (plurality opinion)).

282. Id. at 342 .

283. Id. at 334; see also infra Part ll1.C.1.

284. Rupert Barnes Nacoste, Sources of Stigma: Analyzing the Psychology of Affirmative Action, 12 L. \& POL'Y 175, 190 (1990).

285. Krieger, supra note 174 , at 1263. 
mitigate stigmatic harm - then it is important to examine the stigmatic effects of different policies. In other words, form has a function.

\section{1. "Individualized Consideration" as a Deliberately Opaque Process}

The Court in Grutter stated that "truly individualized consideration demands that race be used in a flexible, nonmechanical way." 286 Justice O'Connor, writing for the majority, found that such a policy existed at the University of Michigan Law School. However, in Gratz, the majority nixed Michigan's undergraduate admissions program on narrow-tailoring grounds. Writing for the Court in Gratz, Chief Justice Rehnquist faulted the undergraduate policy for automatically distributing twenty points to every underrepresented minority applicant. ${ }^{287}$ Rehnquist noted that Justice Powell's Bakke opinion "emphasized the importance of considering each particular applicant as an individual," and noted that the kind of admissions program Powell permitted "did not contemplate that any single characteristic automatically ensured a specific and identifiable contribution to a university's diversity."288

This "identifiable" language is telling. It suggests that the "flexibility" of the approved admissions program in Grutter may serve to conceal or make less clear who precisely is benefiting from consideration based on race. If the admissions process is more opaque, it may be harder to say that race is playing such a large role. If race is playing a smaller role in admissions - if race truly is "one of many" factors and acts only as a small "plus" - such that the applicant and others can never really know whether race played a role in one's admission, then it is possible the stigmatic harm would be reduced. Fuzziness can be a virtue in this setting.

However, perhaps the genie is already out the bottle: everyone knows what admissions offices are doing, and Michigan officials clearly stated when affirmative action was imperiled that the consideration of race must be allowed in order to field a diverse class. ${ }^{289}$ Moreover, one need only compare the undergraduate admissions numbers before and after Michigan switched to a system with individualized consideration to be skeptical that anything has really changed. For the Fall 2004 entering class, Michigan spent $40 \%$ more money on evaluating applicants than it did the previous year under the more mechanical point-based system. ${ }^{290}$ Likely due in part to the increased length of its revamped application, the total number of applicants declined 18\% - and the decline was $23 \%$ for black, Hispanic, and

286. Grutter, 539 U.S. at 334.

287. See Gratz v. Bollinger, 539 U.S. 244, 271-74 (2003).

288. Id. at 271 .

289. See supra Part lil.A.2.

290. Greg Winter, After Ruling, 3 Universities Maintain Diversity in Admissions, N.Y. TIMEs, Apr. 13, 2004, at 22. 
American Indian applicants. ${ }^{291}$ Nevertheless, of the students Michigan admitted, I0\% were applicants from these three groups-a decrease of only I\% from the prior year. ${ }^{292}$ The actual admissions figures also remained relatively stable at other schools that changed to more individualized admissions systems in the year after Gratz. ${ }^{293}$ The form of individualized consideration has a function, but the public availability of the admissions figures and their curious year-to-year stability in the face of brand new evaluation processes make it doubtful that form on its own will reduce stigmatization in this instance.

\section{Admissions Lottery}

A change in form that seems most likely to reduce stigmatic harm would be the adoption of a lottery to determine university admissions. ${ }^{294}$ Under this model, universities would set a floor for applicants' qualifications above which everyone would be deemed qualified for admission to the university. Then, the university would randomly select students from this pool of qualified applicants to admit. Although blind to race, this would virtually guarantee that a certain percentage of minority students would be admitted: the percentage of applicants above the minimumqualification threshold who are racial minorities.

Of course, a lottery would be the most mechanical way of admitting students and consideration would be far from individualized. Justice O'Connor dismissed the lottery option in Grutter for this reason. "Because a lottery would make ... nuanced judgment impossible," $O$ 'Connor wrote, "it would effectively sacrifice all other educational values, not to mention every other kind of diversity."295 The Court in Grutter effectively foreclosed the lottery option as a narrow-tailoring method a court can insist a university consider.

However, one distinct virtue of having a lottery is that it is an admissions procedure that itself does not stigmatize. A quota like the one

291. Brad Heath, U-M Loses Minority Applicants, Detroit News, Feb. 10, 2004, available at http://www.detnews.com/2004/schools/0402/10/a0le-60375.htm. The next year saw an increase in the number of applicants to Michigan, including the number of minority applicants. The University credited this rise to its increased outreach and recruitment efforts aimed at applicants generally and African-American and Hispanic applieants in particular. See Doug Lederman, Upturn for Minority Students at Michigan, INSIDE HIGHER ED, June 7, 2005, http:/www.insidehighered.com/ news $/ 2005 / 06 / 07 /$ mich.

292. Winter, supra note 290 , at 22.

293. Id. ("At Ohio State University, the same racial groups, often referred to as underrepresented minorities, make up 10 percent of this year's admitted class, compared with 12 percent the year before. And at a third campus that scrapped its point system, the University of Massachusetts at Amherst, the pereentage of black, Latino and American Indian students who were accepted remained about 7 percent.").

294. For one examination of the lottery option, see generally Pauline T. Kim, Essay, The Colorblind Lottery, 72 Fordham L. Rev. 9 (2003).

295. Grutter v. Bollinger, 539 U.S. 306, 340 (2003). 
discussed in Bakke, by contrast, would be the most stigmatizing, since minority students in that case were competing in a wholly different admissions procedure than other applicants. A lottery would randomly select applicants. There would still be the problem that in the undergraduate admissions context, for example, minority students are "underrepresented at higher SAT levels and overrepresented at lower SAT levels relative to their proportion in the applicant pool."296 Yet any stigmatization that may come from this disproportion would not be caused by the university's admissions program because the university itself does not cause the disproportion in test scores. A lottery would have its shortcomings and, even aside from Grutter's negative view of lotteries, ${ }^{297}$ these flaws may very well preclude the implementation of a lottery-based admissions regime. ${ }^{298}$ Nevertheless, it is significant that the university itself would not be stigmatizing racial minorities if it were to use a lottery for admissions, yet the university could still achieve a pool of admittees almost nearly as diverse as its pool of applicants.

\section{Pool-Related University Efforts: Outreach, Recruitment, and Helping to Close the Education Gap}

Universities making an effort to increase the number and quality of the supply of minority applicants could increase the diversity of their student bodies while avoiding the stigma that attaches from race-based affirmative action admissions policies. The project here would be to wall off actual admissions decisions (in which race would not be considered) from efforts aimed at affecting the pools of applicants and enrollees (in which

\footnotetext{
296. Liu, supra note 7, at 1064 (citing BOWEN \& BoK, supra note 69, at 20 fig. 2.2). Liu explains: This means that even if selective institutions admitted students solely on the basis of SAT score with no racial preferences (e.g., by admitting applicants in rank order until all the seats are filled, or by setting a minimum SAT threshold above which all applicants are admitted), relatively more black admittees would be found at lower SAT levels, while relatively more white admittees would be found at higher SAT levels.

298. Some people may criticize the fact that the lottery was adopted for the benefit of racial minorities-that the lottery policy is facially "race-blind" but its designers wcre mindful of its racial effects. A much larger problem, however, is that some may interpret the change to a new admissions policy as a statement that minorities could not "cut it" sufficiently in the old system-thus allowing a negative perception of minority qualifications to persist even under the new admissions policy of a colorblind lottery, and even if minority qualifications do eventually rise. It would be simplistic to argue that a lottery would completely cure how minorities' qualifications are perceived. Solving this overall problem is not the project of the lottery, nor is it a fair demand to make of a university designing its admissions system. Rather, the lottery may be more significant in what it does not do: unlike a racial preference, a race-blind lottery does not add any "plus" or admit any students on account of race, and as a result, it does not lead to the stigmatization of admitted minority students' qualifieations vis-à-vis the qualifications of admitted non-minority students based on how such students were admitted-in large part because, aside from the establishment of a minimum threshold, qualifieations generally (i.e., for minorities and nonminorities) are effectively made irrelevant by an admissions system that randomly selects who to admit.
} 
race may be considered). Unlike the decision-making function of admissions, outreach and recruitment efforts are aimed at gathering. Increased pre-decision outreach to improve the diversity of the applicant pool, as well as more post-decision recruitment to encourage those admitted to enroll, are non-stigmatizing efforts that are (or can be) wholly detached from the decision-making process.

Of course, many of the most talented and qualified minority students - that is, the students most likely to be admitted —are already being recruited pre- and post-admission, and efforts to recruit more of them can only do so much. ${ }^{299}$ Still, there are steps schools can take beyond competing for the same few minority students. Universities could also improve the diversity of the pool by increasing it through partnerships with lowperforming public schools-helping to provide better schooling and increased admissions knowledge so that students become more attractive to universities and are encouraged to apply to places and opportunities they might not have ordinarily considered for themselves. Universities could also look outside their own communities to develop partnerships. For example, the University of Vermont has partnered with Christopher Columbus High School, a school located in the Bronx borough of New York City that has many students who are immigrants or children of immigrants from Africa and the Dominican Republic. ${ }^{300}$ "The university makes a direct pitch to students who might not otherwise have Vermont on their radar." ${ }^{\text {301 }}$ The University's admissions officcrs train students in filling out college applications, but their partnership with the school exists before the collcge application season: "Vermont is already working with ninth graders at Columbus to ensure that when they apply, they have the skills and savvy to compete with whitc applicants from more affluent schools." "302 By helping with applications, the University of Vermont is in effect "developing their own pool of minority candidates," 303 and by making efforts to improve the quality of this high school, Vermont is making these students more likely to be admitted. And regardless of whether the students choose to apply to or enroll at Vermont, the University is doing good.

This "doing good" language is more than an effort to appeal to universities' better angels. Society ought to reduce the inequities and increase the

299. Cf. Juliet Chung, For Medical Schools, Minorities Are the Star Recruits, N.Y. Times, Oct. 13, 2004, at B8 (quoting Dr. Jordan J. Cohen, president of the Association of American Medical Colleges, as saying that medical schools' post-admission recruiting programs for minority admittees "are just shifting the zero-sum total. . . They're obviously important from the schools' point of view, but they unfortunately don't serve to get at the problem in the aggregate, which is to increase the number in the total pool.").

300. Jacques Steinberg, University of Vermont Builds Pool of Recruits in the Bronx, N.Y. TIMES, Dec. 26, 2001, at Al.

301. Id.

302. Id.

303. Id. 
overall quality of K-12 education. Universities cannot be asked to do all or most of this, but according to some of the most prominent university presidents, higher education does have a role to play. As Derek Bok editorialized several months after the Grutter and Gratz decisions:

Even as they celebrate, however, educators must also ponder the warning that Justice O'Connor added at the end of her opinion: "We expect that 25 years from now, the use of racial preferences will no longer be necessary to further the interest approved today." If they are to meet Justice O'Connor's deadline, universities will have to overcome a major challenge: closing the gap in academic achievement and standardized test scores separating black and Hispanic students from their white and AsianAmerican counterparts. The gap is nationwide, it is substantial, and it has not diminished in the last 15 years.

The task is all the more difficult because most experts attribute the gap to racial differences in child-rearing, preschool preparation, and opportunities for a quality public-school education. Those are not differences that colleges can do a great deal to overcome. Still, much remains that they can do. ${ }^{304}$

Indeed, universities can do more. Bok mentioned, for example, that "universities can encourage more research to discover the causes of the gap." ${ }^{305}$ Universities already do a great deal in this and other respects for the good of the public, but as Bok pointed out, colleges "are underperforming." "Perhaps," he wrote, "Justice O'Connor's opinion, with its 25 -year timetable, will provide a wake-up call to push educators into doing what they should have been attending to all along. ${ }^{9306}$ Will universities heed Bok's call? Eliminating the gap would require a yeoman's effort, but efforts to close the gap would reduce universities' need for race-based admissions policies, thus reducing the stigmatization associated with such practices. Universities cannot close the gap on their own-and they should not be asked to do so. But they have a role to play - and by doing so, they can mitigate the stigmatization associated with affirmative action.

As Parts III.A and III.B demonstrated, stigmatization is a real harm, yet there is much we do not know about it. Part III.C has shown there is also much universities do not know (or have not yet considered) about whether there are ways they can achieve their goals - or at least some of their goals - associated with having diverse student bodies while employing narrowly tailored options that are targeted to reduce or eliminate

304. Derek Bok, Editorial, Closing the Nagging Gap in Minority Achievement, CHron. OF HIGHER Evuc., Oct. 24, 2003, at B20; see also Lee C. Bollinger, Editorial, My Case, WALL ST. J., June 20, 2003, at A8 ("The society must do more to reduce if not eliminate the inequities of our K-12 system, and universities can do more to help.").

305. Bok, supra note 304.

306. Id. 
stigmatic harm. This hypothetical thought experiment may come to pass, but universities need not wait for a lawsuit to be brought under the new calculus before grappling with the problem of stigmatization. For universities-and for litigants--there is more work to do.

\section{IV}

\section{Conclusion: Future Cases And the Year 2028}

Stigma's opening does not generate easy answers for either side of the traditional affirmative action debate. Indeed, its potential to reorient affirmative action litigation and advocacy and unsettle some common assumptions is perhaps what makes it so enticing. The new calculus provides an opening - a new avenue, an invitation of sorts, and perhaps even an imperative - not only for scholars, judges, and others invested in these complex issues to develop and assess arguments in support of or against a nowbroader panoply of benefits and harms, but also for each actor in this debate to grapple with benefits and harms-especially those with respect to racial minorities - and set out ideas for how this grappling should best occur. Stigma's opening allows for stigmatic concerns to be placed front and center, which is where they belong.

Probing more deeply into the specific benefits and harms that pertain to racial minorities would be an unqualified good. However, should the lawsuits envisioned in Part III's thought experiment be brought? That decision is for prospective litigants who would have to step forward and assert such an injury, not to mention the organizations that would be needed to support them in their expensive court fights. ${ }^{307}$ But if a challenge like Adams's or Baker's were brought, it would represent a new front in the struggle over the constitutionality of affirmative action as practiced by universities, presenting both opportunities and challenges for the front's challengers and defenders. Of primary concern should be the empirical effects of these policies. If it can be proven that affirmative action hurts its purported beneficiaries more than it helps, that should matter-and now, because of Grutter's doctrinal advances, it does. Such a finding, I would

307. Professors Posner and Vermeule have speculated as to why such a challenge by affirmative action's purported beneficiaries has not yet been brought:

Many causal explanations, all plausible but speculative, suggest themselves. In university admissions cases the pool of blacks who would obtain admission under race-neutral criteria may be too small to generate a noticeable number of plaintiffs, although it is hardly clear that the same problem of small numbers obtains in contracting cases or other areas where governments have instituted affirmative action programs. A sociological speculation might be that minority plaintiffs in such cases might encounter heavy social sanctions from other members of the beneficiary class. And a psychological speculation might be that the universal propensity for self-serving bias, which causes perceptions of faimess systematically to correlate with interests, prevents most members of the beneficiary class from developing the indignation or moral outrage about affirmative action programs sufficient to sustain nonremunerative litigation of this sort.

Posner \& Vermeule, supra note 12, at 724. 
argue, should trump any recognized benefits that may accrue to individuals and society at large ${ }^{308}$ But as opposed to stigma arguments being raised by white plaintiffs, which may arouse suspicions of questionable motivations as well as significant standing concerns, and which may enable judges to choose whether to grapple with such arguments or avoid them, ${ }^{309}$ a minority plaintiff who would come forward and challenge an affirmative action policy on stigmatic grounds would bring the issue squarely before the courts. Such an examination-and the work by litigants and "social forces" 310 that would spring forth from such a challenge-would be a good thing for the crafting of affirmative action law and policy in the future.

Since "what's past is prologue" even in the potentially changing field of affirmative action litigation, the experience of the Michigan litigation should inform future players. In August 2003, the University of Michigan unveiled its revised undergraduate admissions policy to conform to the Court's decisions in Grutter and Gratz requiring more "individualized consideration" of applicants. ${ }^{311}$ Future cases involving affirmative action in higher education will likely proceed on two tracks. Most will be Gratz narrow tailoring cases $^{312}$ - cases that do not directly challenge the Grutter compelling interest but are instead concerned with whether a specific admissions plan is individualized enough. ${ }^{313}$ As Curt Levey, director of legal affairs at the Center for Individual Rights during the Michigan litigation, said about the University of Michigan's revised admissions policy, "Thc devil is in the details.... The wording is good, but we're going to be monitoring to see how big a role race plays. ${ }^{.314}$

\footnotetext{
308. But see supra Part II.D.

309. Avoiding an examination of such costs might take the form of merely acknowledging them (for example, "other costs include ...") but not fully grappling with them.

310. See infra text at note 327 .

311. Greg Winter, U. of Michigan Alters Admissions Use of Race, N.Y. TimES, Aug. 29, 2003, at A12.

312. Cf. Gratz v. Bollinger, 539 U.S. 244, 268-69, 275 (2003) (following the Court's decision in Grutter and accordingly rejecting petitioners' challenge to diversity being a compelling interest, but evaluating the specifics of the admissions program at issue in the instant Gratz case and finding the program to not be narrowly tailored); id. at 276 (O'Connor, J., concurring) ("Unlike the law school admissions policy the Court upholds today in Grutter $v$. Bollinger, the procedures employed by the University of Michigan's ... Office of Undergraduate Admissions do not provide for a meaningful individualized review of applicants.") (citation omitted); id. at 281 (Thomas, J., concurring) ("I join the Court's opinion because I believe it correctly applies our precedents, including today's decision in Grutter v. Bollinger. For similar reasons to those given in my separate opinion in that case, however, I would hold that a State's use of racial discrimination in higher education admissions is categorically prohibited by the Equal Protection Clause.") (citations omitted) (emphasis added).

313. Justice Scalia's Grutter dissent predicts this kind of case will arise in the future. See Grutter v. Bollinger, 539 U.S. 306, 348 (2003) (Scalia, J., concurring in part and dissenting in part).

314. Winter, supra note 311 , at A12. Following his tenure at the Center for Individual Rights, Mr. Levey became a staff member in the U.S. Department of Education's Office for Civil Rights. See David Epstein, 2 Years Later, INSIDE HIGHER ED, June 24, 2005, http:/www.insidehighered.com/ news/2005/06/24/ocr (reporting on the release of a study by the NAACP Legal Defense and Education Fund critical of the post-Grutter activities of the Office for Civil Rights).
} 
It is also possible that a few Grutter compelling interest cases will emerge in response to new political or sociological realities that establish or undermine the two new diversity rationales O'Connor has put forth. These Grutter cases are where the stigma argument will be tested. To prepare for these cases, supporters of affirmative action must not dismiss the stigma argument or be blinded by rage at its most prominent advocate, Justice Thomas. Dowd's "disgust[] at someone who could benefit so much from affirmative action and then pull up the ladder after himself" 315 should not become dominant, thereby overwhelming any efforts of supporters of affirmative action to seek stronger (and less angry) ways to overcome Thomas's stigma argument. Otherwise, those who take Thomas seriously will have already left the starting line, while those consumed with past battles will be in danger of being left behind - and of leaving their cause behind in the process.

Affirmative action advocates should also not be lulled by their apparent win in Grutter. Contrary to the beliefs of many supporters, ${ }^{316}$ the Court's rulings were not a decisive victory. (Indeed, they may have made the overall diversity interest more vulnerable. ${ }^{317}$ ) And contrary to the beliefs of some opponents, ${ }^{318}$ they were not a resounding defeat. Both elation and devastation must be tempered. Professor Kathleen Sullivan's words after the 1985 affirmative action decisions remain true and instructive after Grutter and Gratz:

[E]very time a showdown over the issue [of affirmative action] has seemed inevitable in the Supreme Court, both sides have been left still standing when the shooting has stopped. Some affirmative action measures have been voted up and some down, but through it all, the Supreme Court has permitted no decisive victory to either side, nor dealt either side a decisive defeat. ${ }^{319}$

That said, the opponents of affirmative action, having lost their most recent bid to end affirmative action in higher education, have much more to learn from the experience of the Michigan cases than affirmative action's supporters. Chief among these lessons is the force brought to bear by the

315. Dowd, supra note 8, at A25.

316. See, e.g., Bliwise, supra note 258 (noting that James Coleman, a professor and senior associate dean for academic affairs at Duke Law School-and the head of the group that prepared the American Bar Association's amicus brief - called the rulings "a very definitive and decisive victory for affirmative action").

317. See supra Part 11.D.

318. See, e.g., Carol lannone, Editorial, The Kennedy Dissent and the Abomination of Grutter, NAT'l REv. ONLINE, Aug. 1, 2003, http:/www.nationalreview.eom/comment/commentiannone080103.asp ("We must fight this modem-day Dred Scott decision with heart and soul. Conservatives, neoconservatives, traditionalists, classical liberals, Straussians-all those who believe that America is defined by the proposition of individual equality under the law-must pour out their protests with unremitting fervor.").

319. Sullivan, supra note 30 , at 78 . 
amicus briefs filed in support of the University of Michigan. ${ }^{320}$ Justice O'Connor observed in her opinion that "context matters when reviewing race-based governmental action under the Equal Protection Clause."321 Those on the winning side of Grutter marshaled amicus briefs from all corners of society, and the "context" provided by the sheer weight of these briefs seems to have had an effect. ${ }^{322}$ Justice Stevens, for example, gave a great deal of consideration-perhaps a dispositive amount-to the record number of amicus briefs. "In the final analysis," he said in a speech to the Chicago Bar Association after the decisions were handed down, "I thought the real question was who should decide[-]the nine of us sitting in the chambers of the Supreme Court or the accumulated wisdom of the country's leaders. That wisdom was really reflected in a powerful consensus which was expressed in the dark green amicus briefs." ${ }^{323}$ The article summarizing the speech also characterized Stevens as saying

that it was undisputed in the record that minority students competed on an equal basis and they were equally successful while in school and after graduation. According to Justice Stevens, this refuted an article Justice Scalia wrote not long after Bakke, which disapproved of affirmative action programs because of the possibility of stigma on minorities who might be suspected of being less qualified. ${ }^{324}$

Affirmative action opponents missed an opportunity to recruit amicus briefs (say, from people like Shelby Steele who have raised the stigma argument before at length, or better yet, from organizations of young racial minorities who have felt affirmative action's stigmatic effects) to build up their case and try to affect the record. ${ }^{325}$ Part of the problem was the inherent limitation of bringing suit under the old affirmative action litigation

320. Eighty-one pereent of the amicus briefs in Grutter supported the affirmative action plan. Ryan J. Owens \& Lee Epstein, Amici Curiae During the Rehnquist Years, 89 JudiCature 127, 132 $\mathrm{n} .25$ (2005) (excluding briefs filed by individuals). For a recounting of the University of Miehigan's concerted efforts to marshal amicus briefs during its affirmative action litigation, see GrEG STOHR, A Black and White Case: How Affirmative Action Survived Its Greatest Legal Challenge $137-42,177-79,218-20,232-35,247-51,253-54$ (2004).

321. Grutter v. Bollinger, 539 U.S. 306, 327 (2003).

322. See also Greenhouse, supra note 101, at Al ("The context provided by the briefs from Fortune 500 companies, senior military officers, and colleges and universities big and small, public and private, quite clearly won the day for Michigan.").

323. Hyman, supra note 44 , at 6 .

324. Id.

325. But see Owens \& Epstein, supra note 320, at 131 (finding that " $[t]$ he liberal wing of the Court (Stevens, Ginsburg, Souter, and Breyer) more often referenees third-party briefs [in its majority opinions] than does the conservative wing (Kennedy, Rehnquist, Scalia, and Thomas) (46 percent versus 32 percent)"). Interestingly, the percentage of Justice O'Connor's majority opinions in the 1994 2003 Terms in which she cited at least one amicus brief was the second lowest of all the then-Justices. See id. at 132 fig. 6. Only Chief Justice Rehnquist's majority opinions cited amicus briefs less often. See id. 
paradigm. ${ }^{326}$ In any event, in any kind of future case that they bring, opponents of affirmative action would be wise to heed the words of two of their greatest political foes, critical race theorists Charles Lawrence and Mari Matsuda: "Ultimately, the result in any contest over affirmative action has less to do with quality of argument than with the social forces behind the debate." 327

A Grutter case can come at any time if the "social forces" change. But even if the forces do not change, another affirmative action case will surely reach the Court, and it is not too far off. Justice O'Connor said near the end of Grutter that race-conscious admissions policies must be limited in time-that "all governmental use of race must have a logical end point." 328 Since it had been twenty-five years since the Bakke decision, O'Connor said, "[w]e expect that 25 years from now, the use of racial preferences will no longer be necessary to further the interest approved today." 329 Justice Ginsburg, joined by Justice Breyer, wrote a concurring opinion emphasizing that the twenty-five-year expectation mentioned in the Court's decision must be viewed in light of the current reality of unequal opportunities for minority students. For this reason, Ginsburg wrote, "one may hope, but not firmly forecast," that twenty-five years is enough time to make the necessary progress to be able to end affirmative action. ${ }^{330}$ Chief Justice Rehnquist characterized it as "a possible 25-year limitation on the Law School's current program," and said that "these discussions of a time limit are the vaguest of assurances." 331 Thomas, perhaps wishfully, applauded "the Court's holding that racial discrimination in higher education admissions will be illegal in 25 years." ${ }^{332}$ He said he "can understand the imposition of a 25-year time limit only as a holding that the deference the Court pays to the Law School's educational judgments and refusal to change its admissions policies will itself expire." 333 But the most instructive words are Justice Kennedy's, who wrote that O'Connor's mention of twenty-five years is "difficult to assess."

In an interview the day after the Grutter and Gratz opinions were announced, Justice O'Connor said that looking twenty-five years into the

326. Another problem may have been that, relative to its opponents in the Michigan cases, the Center for lndividual Rights (which represented the plaintiffs) did little coalition building, was not adept at politicking, and had fewer resources. See STOHR, supra note 320, at 255-56.

327. See LAWRENCE \& MATSUDA, supra note 26 , at 5 .

328. Grutter v. Bollinger, 539 U.S. 306, 342 (2003).

329. Id. at 343 .

330. Id. at 346 (Ginsburg, J., concurring).

331. Id. at 386-87 (Rehnquist, C.J., dissenting).

332. Id. at 351 (Thomas, J., concurring in part and dissenting in part).

333. Id. at 377 .

334. Id. at 394 (Kennedy, J., dissenting). For one post-decision examination of O'Connor's twenty-five-year language and some jurisprudential issues it may raise, see generally Amar \& Caminker, supra note 6. 
future, "I hope it looks as though we don't need artificial help to fill our classrooms with highly qualified students at the graduate level. ... And if we do our job on educating young people, we can reach that goal."335 $\mathrm{O}^{\prime}$ Connor seems to want educational reforms to remedy the underlying social inequalities that exist along racial lines and make affirmative action policies unnecessary to achieving diverse student bodies. However, what if such reforms are not instituted due to a lack of political will, or if the reforms do not work, or if they are beginning to work but do not close the gap in time? If the status quo mostly holds, the Court seems to have another date already scheduled with affirmative action. As seen above, there is sufficient ambiguity in O'Connor's language almost to guarantee that in twenty-five years some judges will (quite reasonably) see this language as aspirational dicta and others (also quite reasonably) will see it as a firm expiration date. This seems almost certain to lead to a circuit split, in turn leading to affirmative action's probable return to the Court circa 2028..$^{336}$

When a court is faced with an affirmative action case in the future, its equal protection analysis of Grutter's diversity interest(s) may take the shape of the new calculus I described in this Comment. To prevail, litigants and the social forces behind them must come prepared to meet this challenge. The clock is ticking.

335. Greenburg, supra note 82 , at 1 .

336. If not sooner, of course. The Court can take a new affirmative action case whenever it wants; indeed, the recent turnover on the Court (especially the fact that Justice O'Connor's seat is now filled by Justice Alito) may prompt some members to push up the date. Whencver the Court next hears a case concerning affirmative action, the Court may decide to overrule itself with a brand new (non-Grutter) framework - though it need not do so for it to consider stigmatic harm, as this Comment has shown. Indeed, the Court need not design a new diversity interest (and thus abrogate stare decisis) for courts in the meantime to factor in racial stigma; the new calculus has plenty of room for a consideration of this and other harms. 